\title{
3. SITE 367: CAPE VERDE BASIN
}

\author{
The Shipboard Scientific Party,2
}

\section{SITE DATA}

Date Occupied: 3 March 1975 (1840Z)

Date Departed: 10 March 1975 (0238Z)

Time on Site: 6 days, 7 hours, 58 minutes

Position: $12^{\circ} 29.2^{\prime} \mathrm{N}, 20^{\circ} 02.8^{\prime} \mathrm{W}$

Water Depth: 4748 corrected meters (echo sounding)

Bottom Felt With Drill Pipe at: 4758 meters below rig floor

Penetration: 1153 meters subbottom

Number of Holes: 1

Number of Cores: 40

Total Length of Cored Section: 347.0 meters

Total Core Recovered: 174.3 meters

Oldest Sediment Cored:

Depth subbottom: 1146 meters

Nature: Red argillaceous limestone

Age: Kimmeridgian/Oxfordian

Measured velocity: $\sim 3.5 \mathrm{~km} / \mathrm{sec}$

Basement:

Depth subbottom: 1146 meters

Nature: Basalt

Velocity range: $4.3 \mathrm{~km} / \mathrm{sec}$

\section{BACKGROUND AND OBJECTIVES}

The acoustic stratigraphy of the eastern basins of the North Atlantic shows many similarities with that of the North American Basin. A wealth of data collected during the past three years, in particular by ships from Lamont-Doherty Geological Observatory (Vema and Conrad), Woods Hole Oceanographic Institution

'Yves Lancelot, Lamont-Doherty Geological Observatory, Palisades, New York (Co-Chief Scientist); Eugen Seibold, Geologisch-Palaontologisches, Institüt und Museum der Universität Kiel, Kiel, Germany (Co-Chief Scientist); Pavel Cepek, Bundesanstalt für Bodenforschung, Hannover, Federal Republic of Germany; Walter E. Dean, Syracuse University, Department of Geology, Syracuse, New York; Vladislav Eremeev, Institute of Geological Sciences of the Academy of Sciences, Laboratory of Lithology Formation, Moscow, USSR; James Gardner, Deep Sea Drilling Project, Scripps Institution of Oceanography, La Jolla, California; Lubomir F. Jansa, Atlantic Geoscience Centre, Geological Survey of Canada, Bedford Institute of Oceanography, Dartmouth, Nova Scotia; David Johnson, Woods Hole Oceanographic Institution, Woods Hole, Massachusetts; Valery Krasheninnikov, Geological Institute of the Academy of Sciences of the USSR, Moscow, USSR; Uwe Pflaumann, GeologischPalaontologisches, Institüt und Museum der Universität Kiel, Kiel, Germany; J. Graham Rankin, Northeast Louisiana University, Department of Chemistry, Monroe, Louisiana; Peter Trabant, Texas A\&M University, Department of Oceanography, College Station, Texas.

${ }^{2}$ David Bukry, U.S. Geological Survey, La Jolla, California (Tertiary nannofossils).

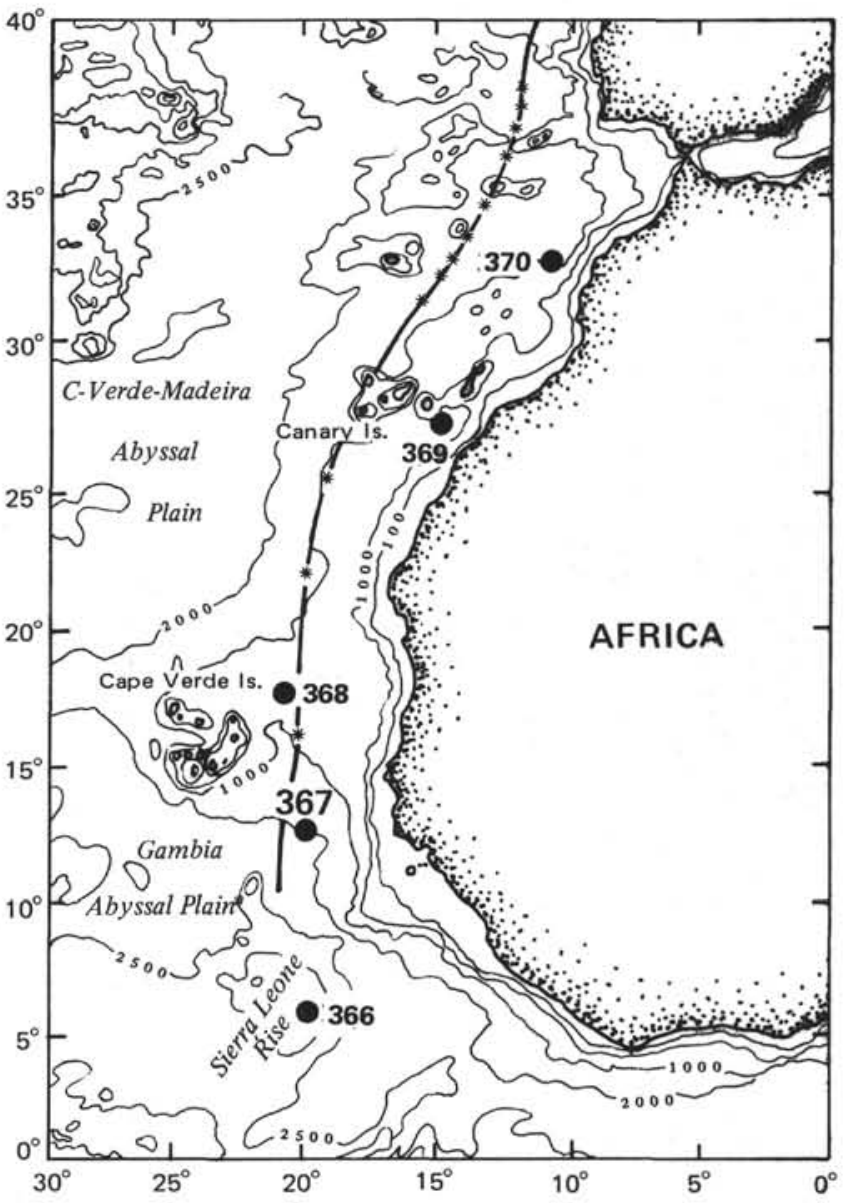

(Atlantis II), and from Bundesanstalt für Geowissenshaften und Rohstoffe of Germany (Meteor), along the northwest African margin provide means to verify the extension of the major reflectors over large areas in the eastern basins. A detailed Lamont-Doherty magnetic survey also provides good control on the inferred postJurassic basement isochrons and the configuration of the rough-quiet magnetic zone boundary (Hayes and Rabinowitz, 1975). Drilling results of Legs 1, 2, and 11 in the western North Atlantic allow a relatively good correlation between the acoustic stratigraphy and different phases of the sedimentary evolution of the North American Basin (Lancelot et al., 1972). Data from Leg 14 on the eastern side of the North Atlantic are too scarce to assess the validity of a symmetrical evolution on both sides of the Mid-Atlantic Ridge (Hayes, Pimm, et al., 1972). Prior to Leg 41 not much was known of the potentially symmetrical evolution of the eastern and western basins during the Mesozoic. Nevertheless, previous work shows that current 
circulation on the bottom was different, at least during the Tertiary, in the two basins. Furthermore, the premiddle Oxfordian evolution of both basins remained completely unknown. Site 367 is located in an area (Figure 1) where all these problems could be approached at the same time.

\section{Background}

The succession of seismic reflectors observed in the deeper parts of the North American Basin can be summarized as follows, from top to bottom: (1) sea floor; (2) Horizon A, (3) Horizon $\beta$; and (4) Horizon B or basement.

Drilling results of Legs 1, 2, and 11 show that Horizon A corresponds to either middle Eocene chert layers or a hiatus near the Cretaceous/Tertiary boundary. A thick series of black clays of early Cretaceous age has been recovered between Horizons A and $\beta$. Horizon $\beta$ is correlated with the top of a basal carbonate sequence of Upper Jurassic to Neocomian age. Horizon B was correlated with basaltic basement (top of layer 2) at Site 100 during Leg 11. However, this lower reflector is still believed to correspond in some cases to sedimentary layers lying just above basaltic basement.

A comparable succession of reflectors can be observed in most of the eastern basins on the eastern side of the North Atlantic. Our comparison is based on the horizontal extension of these reflectors as well as on their actual depth below sea level. If we assume that the depth to oceanic basement is the same on both sides of the Mid-Atlantic Ridge, and if rates of accumulation in the supposedly pelagic section of the sedimentary column is considered to be approximately the same in the eastern and western basins, then the reflectors could correspond to the same age and lithologic boundaries on both sides.

Sites drilled during Leg 11, and particularly Site 105, were located as close to the continental margin as possible where total sediment thicknesses were still compatible with the drilling capabilities of Glomar Challenger. Site 105, at the foot of the continental rise, bottomed in basalt overlain by Oxfordian sediments. No site has been found in the North American Basin where older sediments, hence closer to the continental margin, could be reached because of the presence of a thick prism of Tertiary hemipelagic sediments making up most of the continental rise.

On the eastern side of the North Atlantic, however, the Tertiary continental rise appears much thinner and it is possible to find areas where sediments older than middle Oxfordian could eventually be reached. Several Lamont-Doherty seismic reflection profiles show that when entering the magnetic quiet zone from the east toward Africa the basement (top of layer 2) gradually deepens and disappears beneath a thickening sedimentary section. Some unpublished data from oil companies show the basement to be relatively smooth and at an average depth of 2 to $3 \mathrm{~km}$ below the sea floor in the Cape Verde Basin. A set of reflectors is generally visible within the sedimentary section. In several regions the lowermost of these reflectors, reflector $\mathrm{C}$, abuts the basement around the rough-quiet boundary of the magnetic anomaly profiles (Figure 2). That boundary was found to be approximately middle Oxfordian in age at Site 105 (Leg 11). Therefore, reflector $\mathrm{C}$ was believed to correspond with the top of a pre-middle Oxfordian sedimentary section.

Site 367 is located in the Cape Verde Basin, in an area where reflector $C$ lies exceptionally close to the sea floor (less than $1.1 \mathrm{sec}$ ) (Figure 2). The overlying reflectors can be correlated from profile to profile over the entire Cape Verde and Canary basins.

The site is located on the lower continental rise in the Cape Verde Basin. The rise appears dissected by deepsea channels, as shown by both the PDR and seismic profiles recorded during the approach to the site. The most important of these channels belongs to the Cayar Canyon that cuts deeply into the continental slope just north of Dakar and then is deflected toward the south slightly east of the Cape Verde islands. Several smaller channels can be seen south of Dakar near the base of the slope at the mouth of canyon and slope incisions.

\section{Objectives}

The two major objectives of Site 367 were to determine the nature and age of reflector $\mathrm{C}$ and to compare the sedimentary evolution of the Cape Verde Basin with that of the North American Basin.

\section{Jurassic Evolution}

Until now only the post-Oxfordian history of the Atlantic has been investigated (mainly in the western North Atlantic). It shows a classical example of evolution of an oceanic basin developing between two rifted continental margins. It is characterized by continuous subsidence leading to successive deposition of carbonates and then clays. The middle Oxfordian on the continental margins surrounding the North Atlantic shows an abrupt transgression over continental and lagoonal facies (Haha Basin in Morocco, subsurface data in Nova Scotia). That transgression marks the onset of truly open marine conditions and it shows the first abrupt invasion of ammonite faunas with Tethyan affinities all the way to central Mexico, as recognized already by $\mathrm{C}$. Burckhardt (1906, 1912, 1919). Our objective at Site 367 was to determine the nature of the sediments underlying the Oxfordian sediments in the deep basin in order to understand if in deep water, that time also marks an abrupt facies change. If we assume that the sediments corresponding with reflector $\mathrm{C}$ could be argillaceous limestones of the same Oxfordian-Kimmeridgian "Ammonitico Rosso" facies as in the North American Basin, then it would be extremely interesting to know whether the underlying sediments are of a comparable Tethyan facies. If they are, a communication with the Tethys would have been restricted only to the deep part of the basin because it is not observed on the margins. If the pre-Oxfordian layers display different facies, then it would indicate that the early Atlantic was entirely separated from the Tethys prior to the Oxfordian. In that latter case, the sediments could reflect a restricted environment, possibly with carbonates, or a massive 


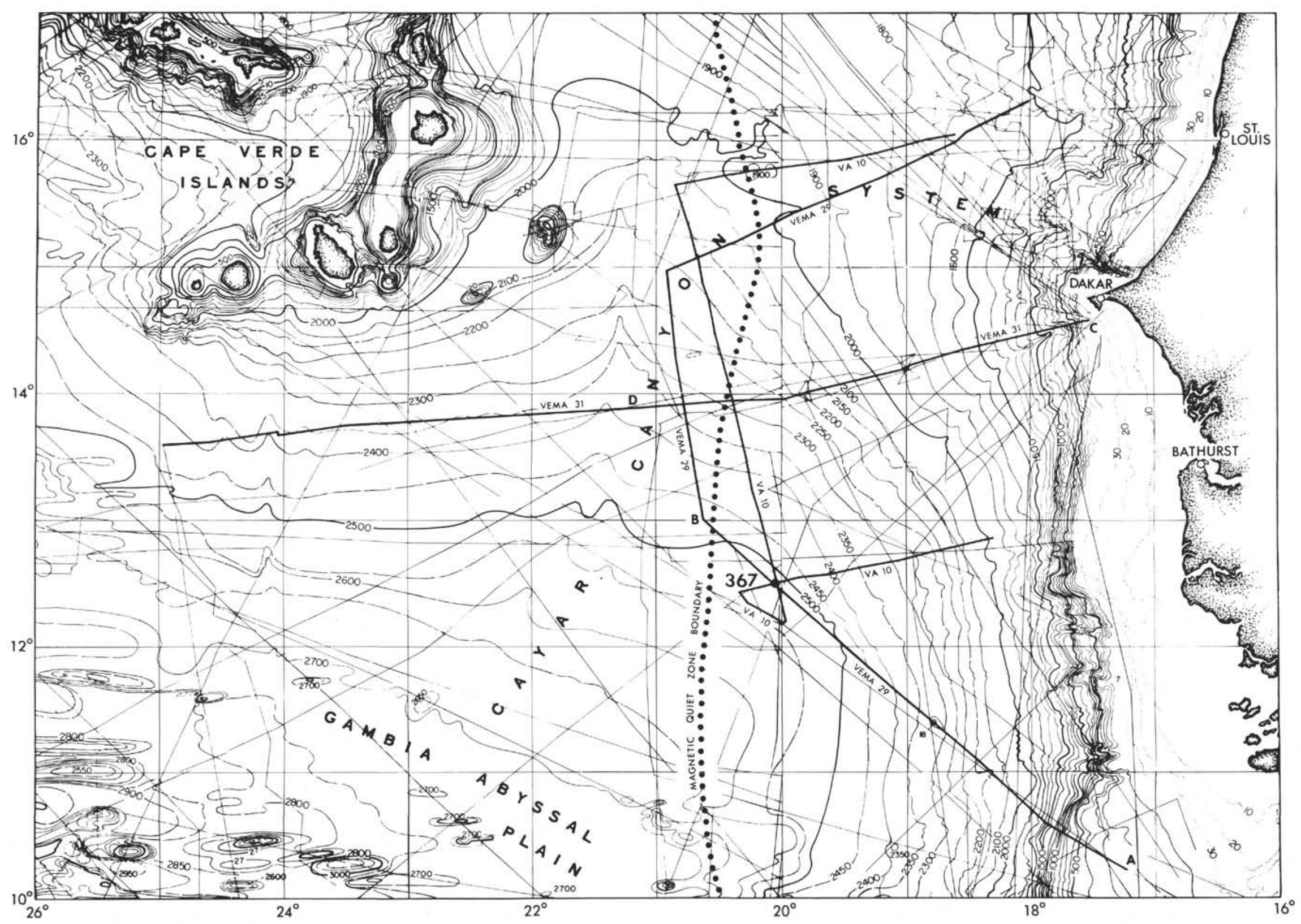

Figure 1. General location of Site 367 in the Cape Verde Basin. Bathymetry from Jacobi and Hayes (in preparation); Magnetic Quiet Zone boundary from Hayes and Rabinowitz (1975). 

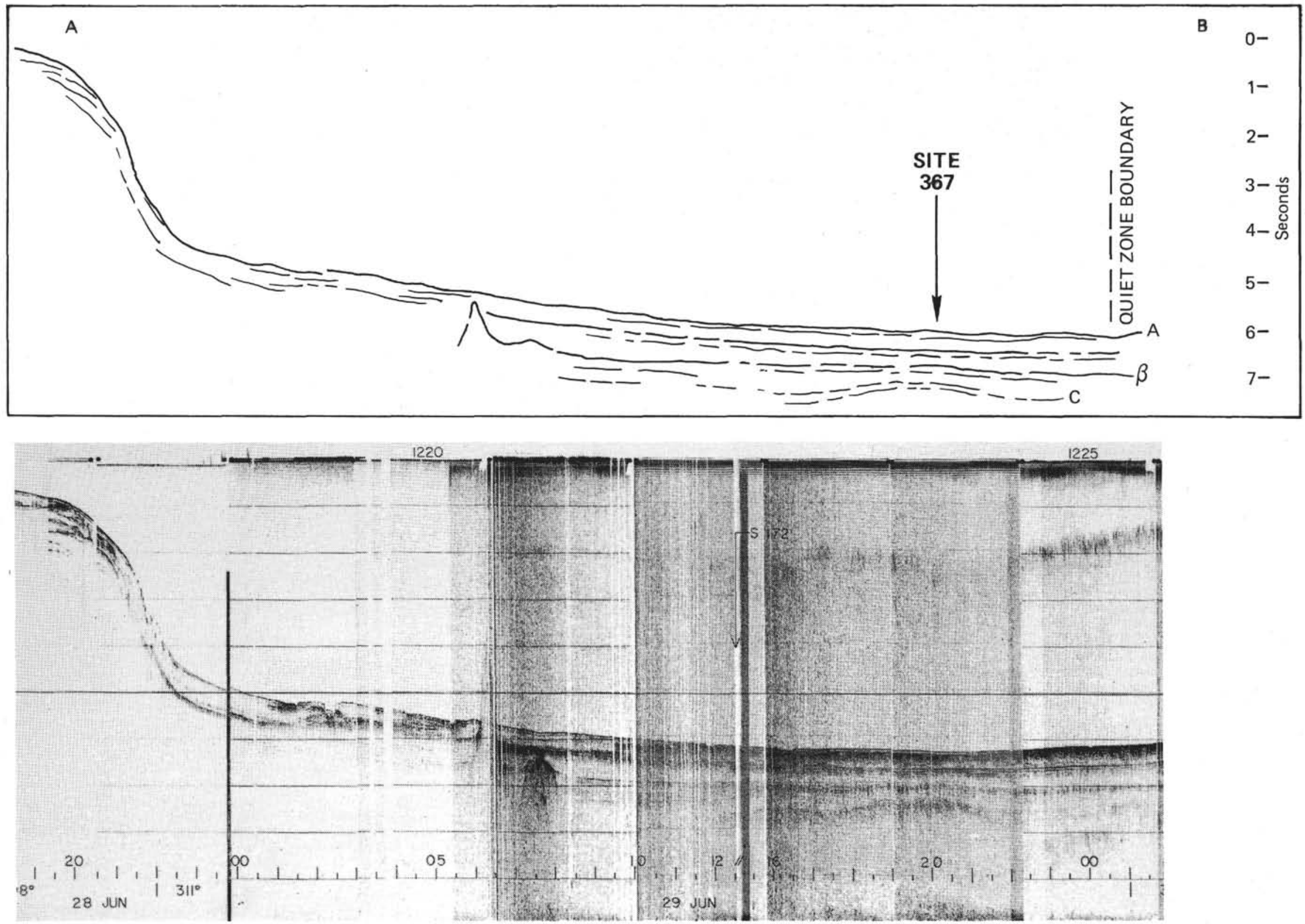

Figure 2a. Lamont-Doherty Geological Observatory Vema 29 seismic profile from the Cape Verde Basin (see location on Figure 1). 

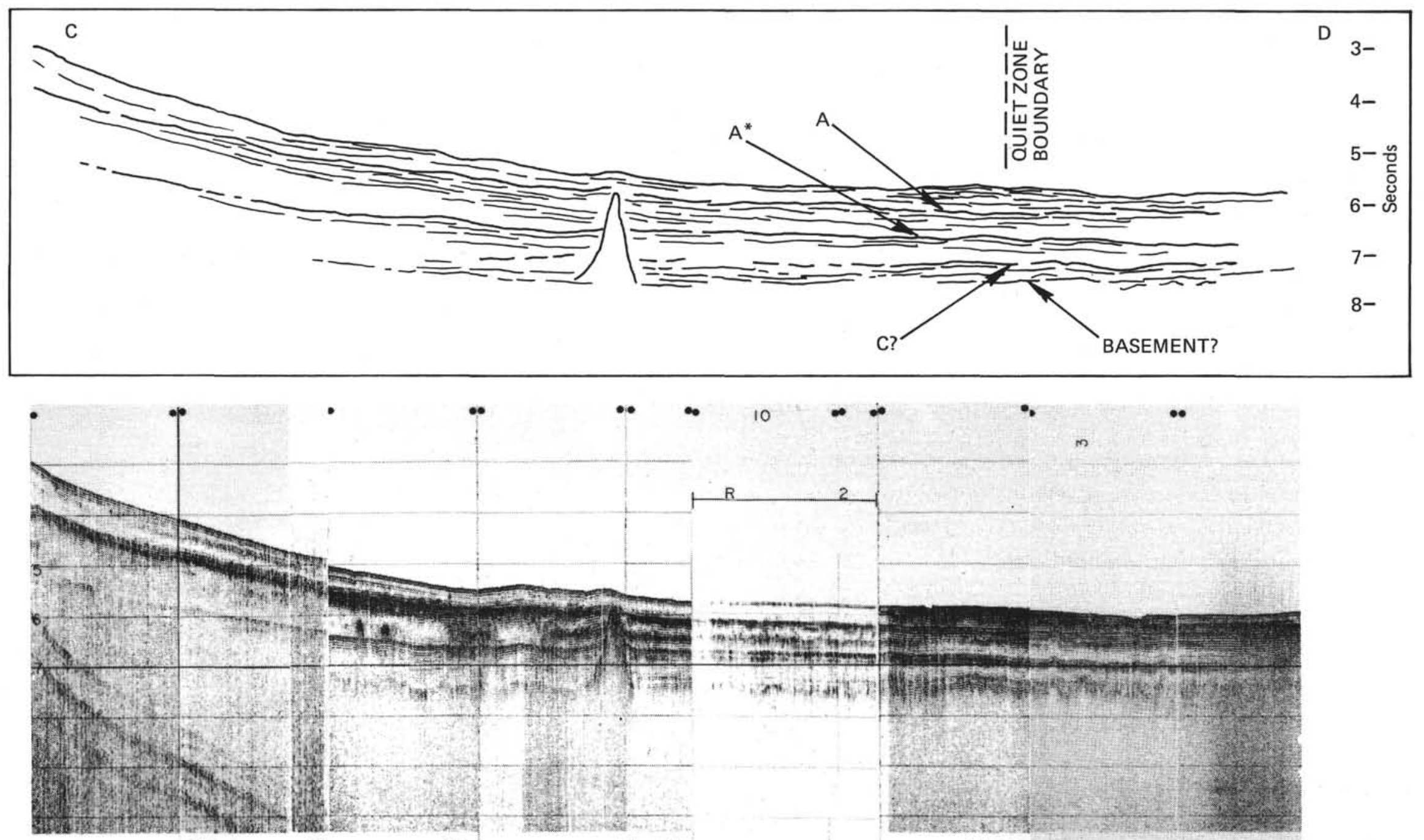

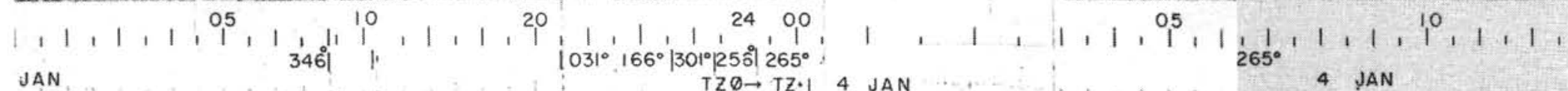

Figure 2b. Lamont-Doherty Geological Observatory Vema 31 seismic profile from the Cape Verde Basin (see location on Figure 1). 
accumulation of terrigenous deposits resulting from a major pre-Oxfordian regression in the young Atlantic.

\section{Subsequent Evolution}

So far the comparison between the North American Basin and the eastern basins is based almost exclusively on geophysical data. A Neocomian succession very similar to Leg 11 profiles was described by Stahlecker (1934) from the island of Maio, Cape Verde islands. Leg 14 results show that there is good reason to believe that Horizons $\mathrm{A}$ and $\beta$ might indeed be of the same age and nature on both sides of the Atlantic. These data are too scarce, however, to establish a good comparison between the two basins. It appeared essential to determine if the history of the North American Basin is only of regional significance or if it corresponds to a more generalized scheme on which possible regional differences could be overprinted. We can already predict from Leg 14 results and from geophysical data that the Tertiary evolution must be somewhat different on both sides of the ocean because the massive terrigenous phase observed in the North American Basin during the post-middle Miocene times (related to the Western Boundary bottom current) does not have an equivalent in the eastern basins where carbonates appear more abundant at that time (less diluted?). The Mesozoic history of the eastern basins is very poorly known and it would be particularly interesting to verify the presence and extension of thick black shale deposits of Early Cretaceous age in the eastern North Atlantic. Periods of restricted bottom circulation during the Aptian-Cenomanian times have been sugg ssted for the South Atlantic and the possible occurrence of such conditions over the entire deep North Atlantic at the same time warranted more investigation. The same remarks apply to the Paleogene and Neogene evolution. Owing to the relatively deep water location of Site $367(\sim 4600 \mathrm{~m})$, it was expected that preservation of the microfossils in the corresponding layers will be rather poor. This younger part of the record would be more easily investigated at Site 368 on the Cape Verde Rise where the water depth is only about 3300 meters and where carbonate deposits were expected. However, the deep location of Site 367 is more favorable for the study of terrigenous deposits possibly derived from the nearby African continental margin. In that respect, such terrigenous "events" might be related to the transgression and regression cycles observed on the margin.

\section{STRATEGY}

Site 367 is located at the base of the continental rise, in the Cape Verde Basin, in 4748 meters of water. The Lamont-Doherty seismic profile (Figure 2) from which the site was selected (profile Vema 29) shows a first prominent reflector at $0.05 \mathrm{sec}$ below the sea floor. This reflector is tentatively correlated with the assumed Oligocene reflector $\mathrm{D}_{2}$ observed on the African margin, the Cape Verde Rise, and the Canary Basin. It could correspond to the widespread Oligocene hiatus reported from many sites drilled in the South and North Atlantic. Below that reflector, at $0.38 \mathrm{sec}$ and $0.71 \mathrm{sec}$, respectively, lie reflectors believed to corre- spond with Horizon $\mathrm{A}$ and Horizon $\beta$. Reflector $\mathrm{C}$ is assumed to be the lowermost reflector (at $1.06 \mathrm{sec}$ ) that rises toward Horizon $\beta$ at the site location. Basement was not clearly visible on the Lamont-Doherty profile, but a post-cruise survey run by the Valdivia (Cruise 101975) shows that the basement lies very close to and just beneath reflector $\mathrm{C}$ (Figure 3). Because of the sediment thickness, reflector $\mathrm{C}$ is only visible in a very discontinuous manner in most of the Cape Verde and Canary basins.

Our drilling strategy called for spot coring of most of the upper section above Horizon $\beta$, then very closely spaced to continuous coring in the lower part. Our penetration was to be limited only by the conditions of both the drill bit and the hole. In the spot-cored section, we would attempt to core all the major reflectors.

\section{OPERATIONS}

Site 367 was approached from the south-southwest on a course following the Lamont-Doherty Vema 29 reference profile. We decided to make the first pass over the area at slow speed ( $\sim 5$ knots $)$ in order to select the most suitable site, and then to come back over the selected target and drop the beacon. After retrieving the seismic and magnetic gear, a second Williamson turn brought the ship back over the beacon (Figure 4). The Glomar Challenger seismic profile recorded at slow speed on a $320^{\circ}$ course (Figure 5) is very comparable to the Vema 29 profile so that the site was easily selected. An ORE $16-\mathrm{kHz}$ double-life beacon was dropped at 1624 hours on 3 March and, after retrieving the gear, at 1740 hours the ship was locked on site at $12^{\circ} 29.2^{\prime} \mathrm{N}$ and $20^{\circ} 02.8^{\prime} \mathrm{W}$. The PDR water depth (from sea level) was recorded as 4748 meters corrected. The site location is almost exactly the same as the proposed site on the Vema 29 reference profile (see Figure 2).

The drill pipe was assembled as soon as the ship was positioned over the beacon. The bottom was felt by the driller at 0335 hours on 4 March when the bit was at 4758 meters below the rig floor. That depth coincides exactly with the water depth (from sea level) recorded by the PDR and the depth of 4748 meters is considered the official one for Site 367. Two cores were obtained just below the sea floor and then intermittent coring was performed until the first cherts were encountered at 331 meters subbottom (see Table 1). Cherty layers were cored continuously and after Core 14, at 388 meters, intermittent coring was resumed. Limestones were encountered at 891 meters, after having cored and drilled through a section consisting mostly of clay, and coring became more closely spaced. The coring operation slowed in very hard, partly silicified limestones slightly below 1000 meters, and it was found that continuous coring would bring the best results in terms of rapid penetration. It was observed while cutting Core 33 that the rate of penetration was slowing down drastically after coring about 5 meters, so from there on the technique consisted of cutting a core until the penetration became almost nil and retrieving the core barrel at that time without attempting to cut a fulllength core. This technique was designed to overcome the possibility of having hard pieces of rock jammed in 

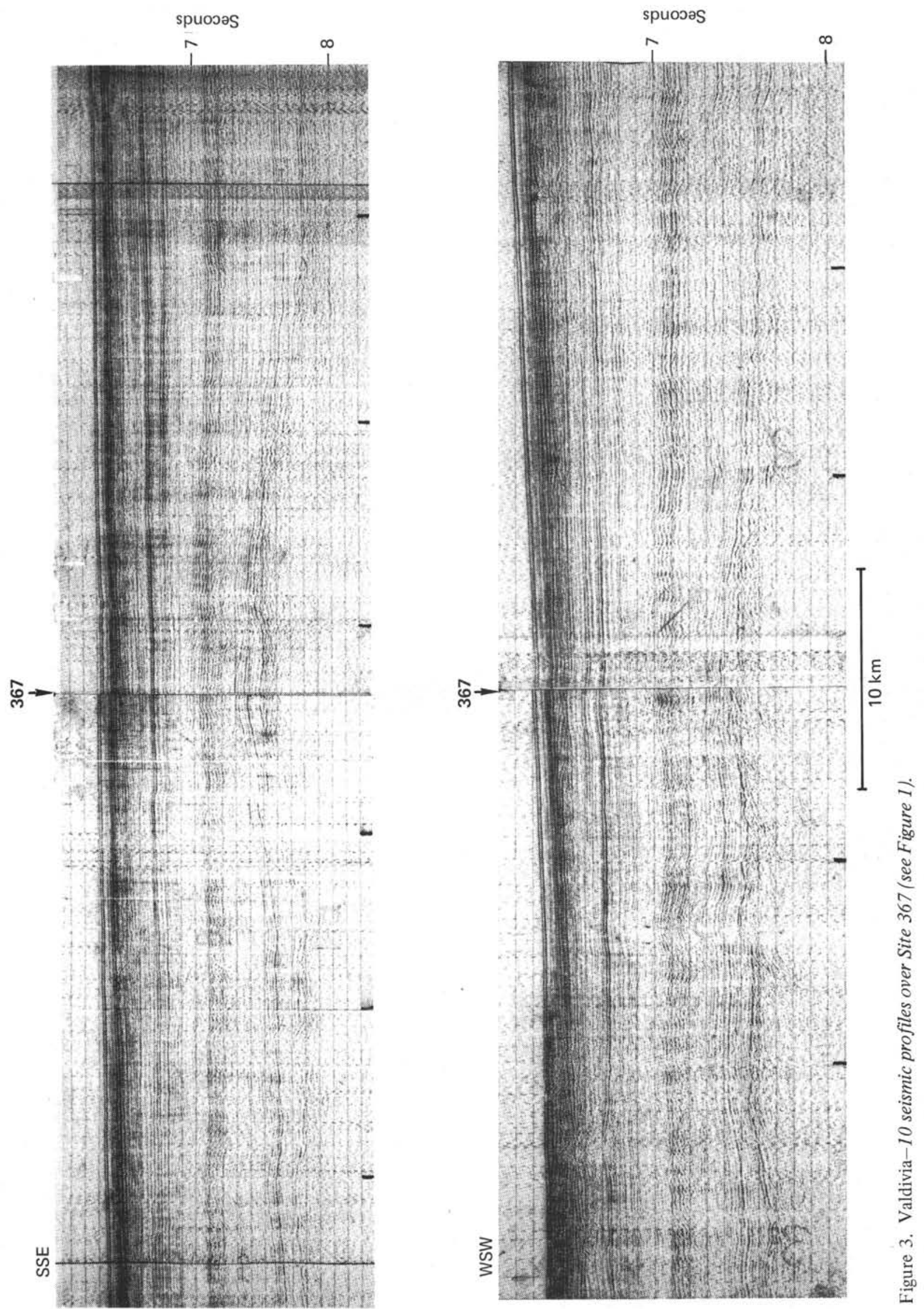


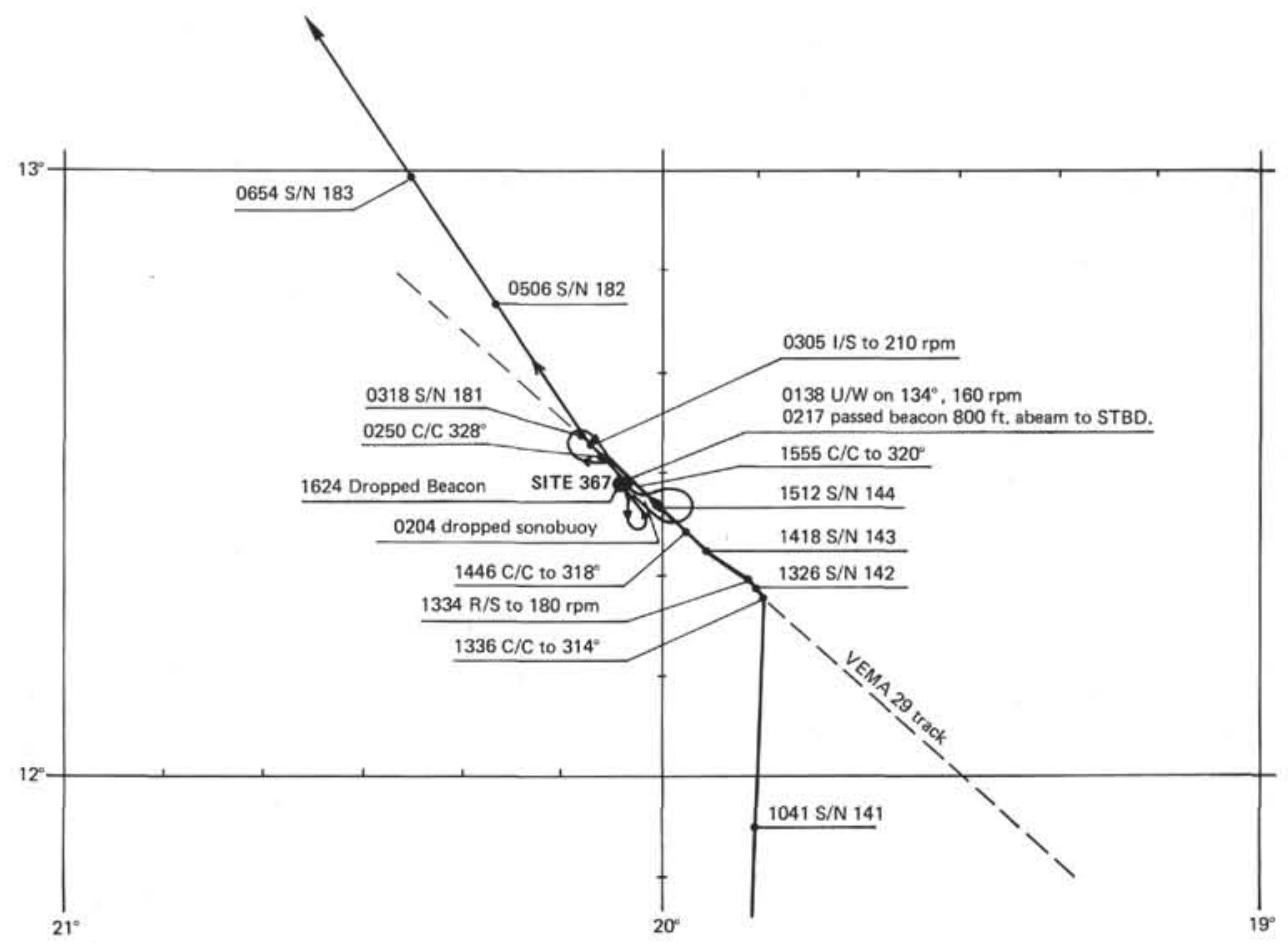

Figure 4. Track chart for the approach and departure of Glomar Challenger from Site 367 (solid line). Dashed line is Vema 29 track.

the core catcher, preventing any further recovery inside the core barrel. Penetration was nevertheless extremely slow and from Core 33 down, the time spent cutting each core varied from just over 2 hours to more than 4.5 hours. Basalt was encountered in Core 38 at 1146 meters and the penetration rate decreased abruptly when cutting the next two cores. While cutting Core 40 the torque increased abruptly and eventually rotation became impossible. The drill string would rotate only when the bit was lifted from the bottom of the hole. After several unsuccessful attempts at rotating the drill string, it was decided to pull out of the hole after having reached a total penetration of 1153 meters.

\section{LITHOLOGY}

We subdivided the section in the Cape Verde Basin into seven lithologic units (Table 2), based on composition and color.

\section{Unit 1-Nannofossil Marl Interbedded With Quartz Sand (Cores 1 through 7)}

This unit is composed of foraminifer nannofossil marl which alternates with quartz sand and rare foraminifer nannofossil ooze. The marls are moderate to dark yellowish brown (10YR5/2 to $10 \mathrm{YR} 4 / 1)$ and in Core 2, dark gray (N3) and have $\mathrm{CaCO}_{3}$ values around $40 \%$. The sand and silty clay are dark greenish gray $(5 \mathrm{GY} 3 / 1)$ and various shades of yellowish brown (10YR4/4). Beds up to 1 meter thick of highly disturbed fine- to coarse-grained quartz sand occur in Cores 3, 4, and 5. The major sediment components are abundant nannofossils, rare to common foraminifers, radiolarians, and rare diatoms, sponge spicules, and fish debris. The terrigenous components are clay, abundant to rare quartz, rare to common feldspar, and heavy minerals (zircon, titanite, rutile, and leucoxene). Mica, glauconite, and pyrite are very rare and manganese(?) flakes occur occasionally. Thin-section examinations also show rare euhedral dolomite rhombs. Intense drilling disturbance of this unit precludes any detailed description of sedimentary structures and contacts.

Core 6 contains nannofossil marl interbedded with stiff yellowish brown (10YR4/4) silty clay which grades downward to greenish gray silty clay $(5 \mathrm{YR} / 2)$ in Core 7. The silty clay is characterized by a lack of biogenic carbonate, common quartz, silt, and clay. Fine particles, especially abundant in Core 7, may be palygorskite, identified in sediments of a similar age at Site 140 (von Rad and Rosch, 1972).

\section{Unit 2}

\section{Subunit 2a-Diatom-bearing Radiolarian Clay (Core 8)}

This subunit has alternating greenish gray (5GY6/1) and black (N1), diatom-bearing radiolarian clay. The black clay layers are about $10 \mathrm{~cm}$ thick and occur about every $30 \mathrm{~cm}$. They always have a sharp lower boundary, and either a sharp or a gradational upper boundary. The black clay is rarely bioturbated, but the greenish gray clay has frequent Zoophycos and sporadic Chondrites. The sediment is stiff to semilithified. Radiolarians are abundant, diatoms are common, and sponge spicules, nannofossils, and fish debris are rare. The nonbiogenic components are abundant clay, rare quartz grains, and heavy minerals and, in the black clay, traces of iron monosulfide(?). 


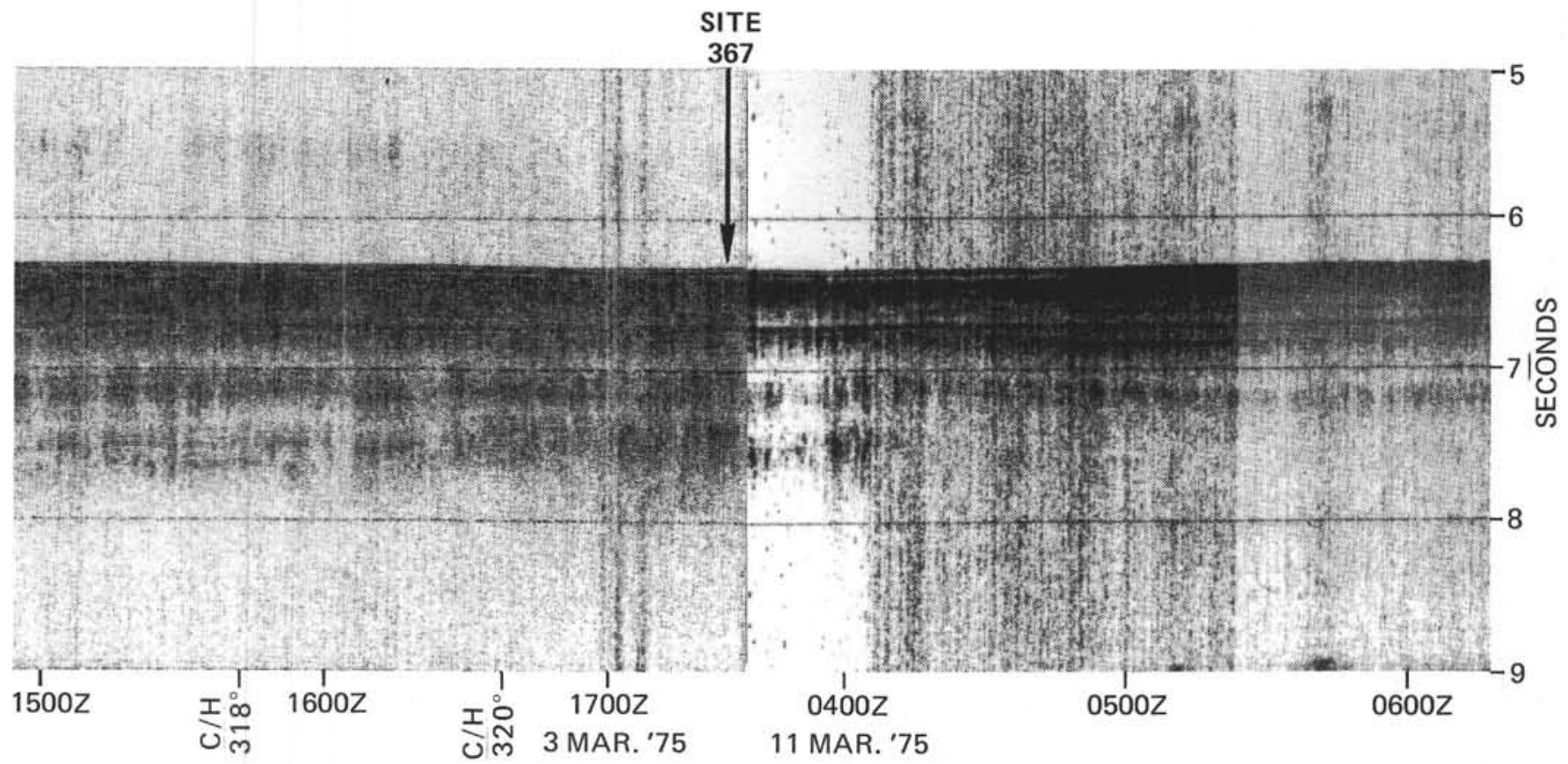

Figure 5. Seismic profile section approaching and leaving Site 367.

\section{Subunit 2b-Zeolitic Clay With Chert and Porcellanite (Cores 9 through 14)}

This subunit is a zeolitic clay with chert nodules and porcellanite. The clay is stiff, dark greenish gray $(5 \mathrm{GY} 4 / 1)$ to dark yellowish green $(5 \mathrm{GY} 5 / 2)$ alternating with black (N1) clay. The black clay beds are about $10 \mathrm{~cm}$ thick and both contacts are usually sharp; they are less abundant than in Subunit 2a.

The greenish gray clay beds are finely laminated and burrowed. They are composed of abundant clay, common to abundant clinoptilolite. and traces of heavy minerals.

The composition of the black clay beds is similar to that of the greenish clay beds but with the addition of rare radiolarians, nannofossils, foraminifers, fish remains, chlorite, and glauconite. Iron oxide (?) micronodules are common. Several fine-sand laminae, composed of subangular well-sorted quartz grains, occur in Core 14, Sections 2 and 3. The lower boundary of the unit is placed above the base of Core 14 .

\section{Unit 3-Multicolored Silty Clay (Cores 14, CC through 17)}

This unit consists predominantly of grayish bluegreen (5BG5/2) and reddish brown (10R3/4) silty clay, separated by sharp boundaries. The sediment has mottled zones, faint horizontal laminations, and is slightly bioturbated. Thin laminae of clayey sand and one porcellanite bed occur in Core 15. Quartz predominates in the upper part of the unit but decreases with depth. The quartz grains are subangular and commonly contain sagenite (rutile needles). Iron oxides, zeolites, feldspars (plagioclase and orthoclase), and heavy minerals (titanite, rutile, and pyrite) are rare. Chlorite, euhedral carbonate crystals, radiolarians, and fish debris occur occasionally. The grayish blue-green
(5BG5/2) clay in Core 17 contains thin interbeds of black (N1) shale, indicating a gradational boundary between Units 3 and 4.

\section{Unit 4}

\section{Subunit $4 a-B l a c k$ Shale (Cores 18 through 23)}

This subunit is a black, carbonaceous shale, which burns when ignited. The content of organic carbon in this shale varies from $8 \%$ to $28 \%$. Plant fragments and well-preserved fish debris occur on bedding planes of the shale (Figure 6). Thin laminae of quartz silt occur in the lower part of the black shale sequence (Core 18). The laminae in Core 19 are light gray and composed of a clayey foraminifer sand. These have sharp lower contacts and gradational upper contacts. The laminae in Cores 20 through 23 are light green and olive-gray and are composed of clayey nannofossil chalk, foraminifers, nannofossil marl, and nannofossilbearing clay. Analyses of Sample 21, CC show abundant ankerite and calcite. The black shale becomes more calcareous, finely laminated, and burrowed with depth. The $\mathrm{CaCO}_{3}$ content measured in one of the laminae was $34 \%$ (carbonate bomb analysis). Within this subunit, clay is dominant to abundant, quartz is rare but becomes more common in the lower part. Organic debris and palynomorphs are frequent. Pyrite and heavy minerals (rutile, titanite, and tourmaline) are rare. Clinoptilolite occurs in the upper part of the subunit. Foraminifers and nannofossils are rare to common throughout. Bioturbation is very rare and was observed only in dark grayish green laminae.

\section{Subunit $\mathbf{4 b}-$ Variegated Claystone (Core 24)}

This subunit is a bioturbated, dark reddish brown (10R3/4), dark greenish gray (5G4/1), and dark gray (N3) claystone highly disturbed by drilling. It contains 
TABLE 1

Coring Summary For Site 367

\begin{tabular}{|c|c|c|c|c|c|c|c|}
\hline Core & $\begin{array}{c}\text { Date } \\
\text { (March 1975) }\end{array}$ & Time & $\begin{array}{l}\text { Depth Below } \\
\text { Drill Floor } \\
(\mathrm{m})\end{array}$ & $\begin{array}{c}\text { Depth Below } \\
\text { Sea Floor } \\
(\mathrm{m})\end{array}$ & $\begin{array}{c}\text { Cored } \\
(\mathrm{m})\end{array}$ & $\begin{array}{c}\text { Recovered } \\
(\mathrm{m})\end{array}$ & $\begin{array}{c}\text { Recovery } \\
(\%)\end{array}$ \\
\hline 1 & 4 & 0437 & $4758.0-4766.0$ & $0.0-8.0$ & 8.0 & 7.9 & 99 \\
\hline 2 & 4 & 0553 & $4766.0-4775.5$ & $8.0-17.5$ & 9.5 & 9.0 & 95 \\
\hline 3 & 4 & 0738 & $4812.0-4821.5$ & $54.0-63.5$ & 9.5 & 3.2 & 34 \\
\hline 4 & 4 & 0856 & $4821.5-4831.0$ & $63.5-73.0$ & 9.5 & 7.7 & 81 \\
\hline 5 & 4 & 1112 & $4908.5-4918.0$ & $150.5-160.0$ & 9.5 & 1.0 & 11 \\
\hline 6 & 4 & 1435 & 4994.0-5003.5 & $236.0-245.5$ & 9.5 & 1.1 & 12 \\
\hline 7 & 4 & 1620 & $5003.5-5013.0$ & $245.5-255.0$ & 9.5 & 0.55 & 6 \\
\hline 8 & 4 & 2149 & $5060.5-5070.0$ & $302.5-312.0$ & 9.5 & 7.3 & 77 \\
\hline 9 & 5 & 0207 & $5089.0-5098.5$ & $331.0-340.5$ & 9.5 & 1.1 & 12 \\
\hline 10 & 5 & 0422 & $5098.5-5108.0$ & $340.5-350.0$ & 9.5 & 0.4 & 4 \\
\hline 11 & 5 & 0624 & $5108.0-5117.5$ & $350.0-359.5$ & 9.5 & 0.8 & 8 \\
\hline 12 & 5 & 0844 & $5117.5-5127.0$ & $359.5-369.0$ & 9.5 & 1.7 & 18 \\
\hline 13 & 5 & 1120 & $5127.0-5136.5$ & $369.0-378.5$ & 9.5 & 4.0 & 42 \\
\hline 14 & 5 & 1655 & $5136.5-5146.0$ & $378.5-388.0$ & 9.5 & 5.25 & 55 \\
\hline 15 & 5 & 2126 & $5231.5-5241.0$ & $473.5-483.0$ & 9.5 & 6.3 & 66 \\
\hline 16 & 6 & 0211 & $5298.0-5307.5$ & $540.0-549.5$ & 9.5 & 8.6 & 91 \\
\hline 17 & 6 & 0504 & $5374.0-5383.5$ & $616.0-625.5$ & 9.5 & 5.3 & 56 \\
\hline 18 & 6 & 0722 & $5394.0-5402.5$ & $636.0-644.5$ & 8.5 & 6.9 & 81 \\
\hline 19 & 6 & 1232 & $5402.5-5412.0$ & $644.5-654.0$ & 9.5 & 4.7 & 50 \\
\hline 20 & 6 & 1438 & $5442.5-5450.0$ & $684.5-692.0$ & 7.5 & 5.0 & 67 \\
\hline 21 & 6 & 1800 & $5450.0-5459.5$ & $692.0-701.5$ & 9.5 & 7.9 & 83 \\
\hline 22 & 6 & 2241 & $5478.5-5488.0$ & $720.5-730.0$ & 9.5 & 8.0 & 84 \\
\hline 23 & 7 & 0328 & $5535.5-5545.0$ & $777.5-787.0$ & 9.5 & 3.1 & 33 \\
\hline 24 & 7 & 0835 & $5592.5-5602.0$ & $834.5-844.0$ & 9.5 & 3.4 & 36 \\
\hline 25 & 7 & 1228 & $5649.5-5659.0$ & $891.5-901.0$ & 9.5 & 6.1 & 64 \\
\hline 26 & 7 & 1632 & $5668.5-5678.0$ & $910.5-920.0$ & 9.5 & 5.6 & 59 \\
\hline 27 & 7 & 2020 & $5607.0-5706.5$ & $939.0-948.5$ & 9.5 & 4.1 & 43 \\
\hline 28 & 7 & 2355 & $5725.5-5735.0$ & $967.5-977.0$ & 9.5 & 4.1 & 43 \\
\hline 29 & 8 & 0443 & $5754.0-5763.5$ & $996.0-1005.5$ & 9.5 & 2.7 & 28 \\
\hline 30 & 8 & 1300 & $5782.5-5792.0$ & $1024.5-1034.0$ & 9.5 & 3.2 & 34 \\
\hline 31 & 8 & 1800 & $5811.0-5820.5$ & $1053.0-1062.5$ & 9.5 & 2.9 & 31 \\
\hline 32 & 8 & 2343 & $5839.5-5849.0$ & $1081.5-1091.0$ & 9.5 & 6.6 & 70 \\
\hline 33 & 9 & 0326 & $5863.5-5869.0$ & $1105.5-1111.0$ & 5.5 & 4.5 & 82 \\
\hline 34 & 9 & 1006 & $5869.0-5877.5$ & $1111.0-1119.5$ & 8.5 & 5.5 & 65 \\
\hline 35 & 9 & 1613 & $5877.5-5885.5$ & $1119.5-1127.5$ & 8.0 & 7.1 & 89 \\
\hline 36 & 9 & 2002 & $5885.5-5893.0$ & $1127.5-1135.0$ & 7.5 & 3.7 & 49 \\
\hline 37 & 9 & 2358 & $5893.0-5900.0$ & $1135.0-1142.0$ & 7.0 & 1.4 & 20 \\
\hline 38 & 10 & 0342 & $5900.0-5906.0$ & $1142.0-1148.0$ & 6.0 & 3.4 & 57 \\
\hline 39 & 10 & 0920 & $5906.0-5909.0$ & $1148.0-1151.0$ & 3.0 & 2.0 & 67 \\
\hline 40 & 10 & 1413 & $5909.0-5911.0$ & $1151.0-1153.0$ & 2.0 & 1.2 & 60 \\
\hline Total & & & & & 347.0 & 174.3 & 50 \\
\hline
\end{tabular}

scattered quartz silt, rare zeolites, rare radiolarian casts filled with a mixture of chalcedony and clay, but the dominant component of the subunit is clay. The reddish brown claystone in Sample 24, CC is underlain by a medium gray shale which is very finely laminated by light gray carbonate. The laminae are lenticular and less than $1 \mathrm{~mm}$ in thickness. The core-catcher sample indicates a transitional contact between Units 4 and 5 .

\section{Unit 5}

\section{Subunit 5a-Light Gray Nannofossil Limestone, Interbedded With Olive Marlstone and Black Shale (Cores 25 through 27)}

This subunit differs substantially from the overlying sequence. It is a light gray (N7) to medium gray (N5) massive limestone. The limestone is interbedded with moderately soft, olive-gray $(5 \mathrm{Y} 4 / 1)$ and laminated nannofossil marlstone. Aptychi occur in the marlstone. The light gray limestone is bioturbated, slightly recrystallized, and composed of a microsparite enclosing nannofossils. The marlstone is composed of abundant clay, quartz silt, rare iron oxide(?) micronodules, traces of pyrite, and heavy minerals. Thinsection observations revealed rare feldspars, fish debris, and organic matter. Nannofossils are abundant and foraminifers are rare. Nannoconus is present in Cores 26 and 27. Poorly preserved calpionelloids occur in trace amounts in Core 27. Casts of radiolarians replaced by calcite are frequent throughout Unit 5, occurring mostly in the light gray limestone. The marl in Core 27 becomes varicolored and encloses thin beds in olive black shale.

\section{Subunit $5 \mathrm{~b}-\mathrm{Nannofossil}$ Limestone With Marl and Chert (Cores 28 to 32-5)}

The top of Subunit $5 \mathrm{~b}$ is an alternating nannofossilbearing limestone and olive-gray $(5 \mathrm{Y} / 1)$, finely laminated marlstone. The content of argillaceous matter increases with depth. The argillaceous nannofossil-bearing limestone is pale yellowish brown (10YR6/2), finely laminated, and frequently 
TABLE 2

Lithostratigraphy at Site 367

\begin{tabular}{|c|c|c|c|}
\hline Unit & Lithology & Cores & Age \\
\hline 1 & $\begin{array}{l}\text { Foraminifer-nannofossil marl } \\
\text { with quartz sand }\end{array}$ & $\begin{array}{l}1 \text { through } 7 \\
(0.0 \text { to } 255.0 \mathrm{~m})\end{array}$ & Pleistocene to Miocene \\
\hline $2 \mathrm{a}$ & Diatom-bearing radiolarian clay & $8(302.5$ to $312.0 \mathrm{~m})$ & Late Eocene \\
\hline $2 \mathrm{~b}$ & $\begin{array}{l}\text { Zeolitic clay with chert and } \\
\text { porcellanite }\end{array}$ & $\begin{array}{l}9 \text { through } 14 \\
(331.0 \text { to } 338.0 \mathrm{~m})\end{array}$ & Eocene to late Paleocene \\
\hline 3 & Multicolored silty clay & $\begin{array}{l}14, \mathrm{CC} \text { through } 17 \\
(388.0 \text { to } 625.5 \mathrm{~m})\end{array}$ & $\begin{array}{l}\text { Late Paleocene/early Eocene to } \\
\text { Late Cretaceous }\end{array}$ \\
\hline $4 a$ & Black shale & $\begin{array}{l}18 \text { through } 23 \\
(636.0 \text { to } 787.0 \mathrm{~m})\end{array}$ & $\begin{array}{l}\text { Early Turonian to late Aptian/ } \\
\text { early Albian }\end{array}$ \\
\hline $4 b$ & Variegated claystone & $24(834.5$ to $844.0 \mathrm{~m})$ & Late Aptian to early Albian \\
\hline $5 \mathrm{a}$ & $\begin{array}{l}\text { Light gray nannofossil lime- } \\
\text { stone, olive marlstone, and black } \\
\text { shale }\end{array}$ & $\begin{array}{l}25 \text { through } 27 \\
(891.5 \text { to } 948.5 \mathrm{~m})\end{array}$ & $\begin{array}{l}\text { Late Aptian/early Albian to } \\
\text { Hauterivian }\end{array}$ \\
\hline $5 \mathrm{~b}$ & $\begin{array}{l}\text { Nannofossil limestone, marl, } \\
\text { and chert }\end{array}$ & $\begin{array}{l}28 \text { through } 32-5 \\
(948.5 \text { to } 1089 \mathrm{~m})\end{array}$ & $\begin{array}{l}\text { Valanginian/Hauterivian to } \\
\text { Oxfordian/Kimmeridgian }\end{array}$ \\
\hline 6 & $\begin{array}{l}\text { Reddish brown nannofossil- } \\
\text { bearing argillaceous limestone, } \\
\text { marl, clays, and chert }\end{array}$ & $\begin{array}{c}32-5 \text { through } 38-2 \\
(1089.0 \text { to } 1144.0 \mathrm{~m})\end{array}$ & $\begin{array}{l}\text { Not older than Oxfordian to } \\
\text { Kimmeridgian }\end{array}$ \\
\hline 7 & Basalt & $\begin{array}{l}38-2 \text { through } 40 \\
\text { (1144.0 to } 1153.0 \mathrm{~m}) \\
\text { (T.D.) }\end{array}$ & \\
\hline
\end{tabular}

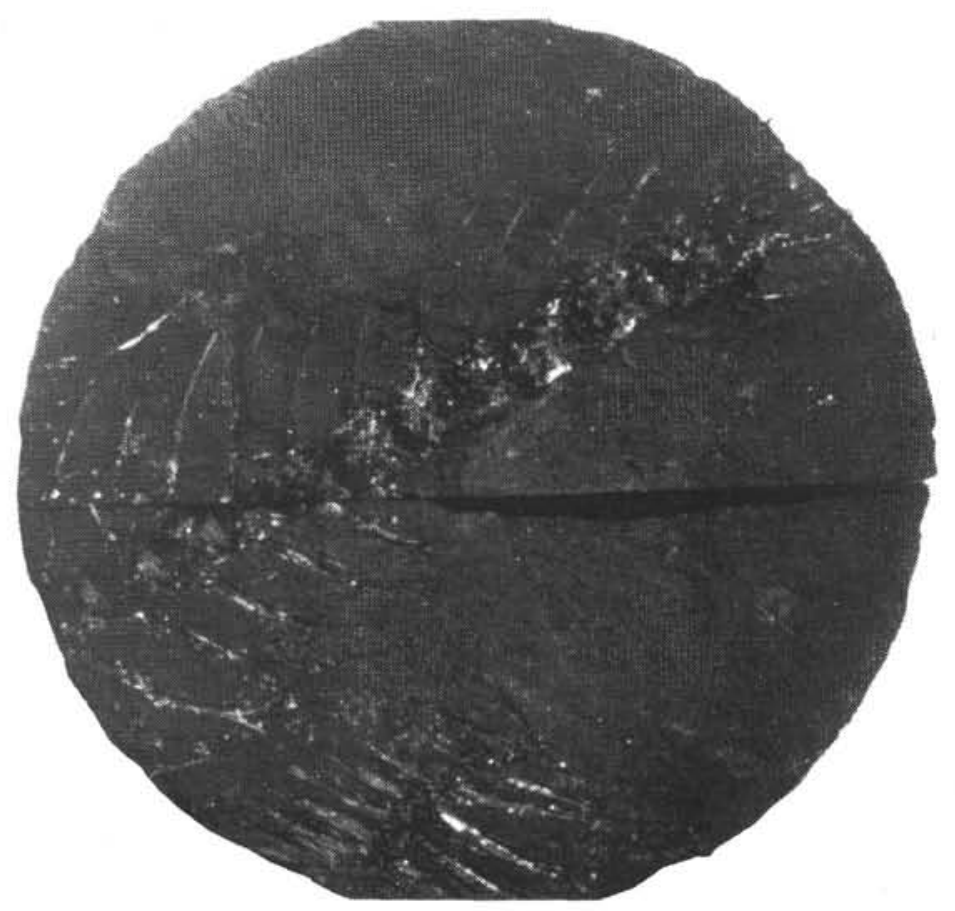

Figure 6. Fish vertebrae recovered from lithologic Subunit $4 a$. Core diameter is $6.5 \mathrm{~cm}$.

bioturbated. Medium gray (N6) chert and medium light gray and dark greenish gray $(5 \mathrm{GY} 6 / 1)$ procellanite occur sparsely from Core 29 to the base of Subunit 5 b. Thin beds of olive-black shale alternate with limestone beds in Core 28; poorly preserved calpionelloids(?) occur in trace amounts in Core 29. The composition of Subunit $5 \mathrm{~b}$ is similar to Subunit 5a. Aptychi are relatively common in the marlstone. Low-amplitude stylolites first occur in Core 31 . The boundary with the underlying unit is placed at the top of the reddish brown limestone sequence occurring in Core 32, Section 5 .

\section{Unit 6-Reddish Brown Nannofossil-bearing Argillaceous Limestone Interbedded With Marl, Clay and Chert (Cores 32-5 through 40)}

The nannofossil-bearing argillaceous limestone is light brownish gray $(5 \mathrm{YR} 6 / 1)$ to dark reddish brown 
$(2.5$ YR 2.5/5) with fine, wavy laminations. The limestone is bioturbated and frequently displays a nodular texture. Reddish brown limestone alternates with very light gray (N8) microcrystalline limestone, the latter being massive, mottled, and having stylolites. There is a slight change in composition and color from Core 33 downward. Reddish brown limestone alternates with thin (less than $5 \mathrm{~cm}$ ) greenish gray $(5 \mathrm{G} 5 / 2)$ claystone beds and laminae. The limestone becomes more argillaceous toward the base of the unit. Porcellanite and chert occur sporadically but always occur above a clay or red marlstone bed. Three microfacies can be recognized on the basis of the biogenic content. The Saccocoma-aptychi microfacies (Core 32, Section 5 to Core 35, Section 2) is characterized by very common planktonic echinoids (Saccocoma) and aptychi fragments in the marlstone. The matrix is a nannofossil-bearing clayey micrite. The light gray limestone in this microfacies is composed of microsparite with frequent casts of radiolarians replaced by calcite. A change of microfacies occurs at the top of Core 35, Section 3. Here a flood of long, parallel-oriented filaments (planktonic lamellibranches) occurs. Core 36 has predominantly short filaments which show a lower degree of preferential orientation parallel to the bedding planes. Saccocoma and aptychi are rare. Radiolarians and nannofossils replaced by calcite are common. Filaments occur in both the marl and the argillaceous limestone. The light gray limestone of the filamentous microfacies is slightly recrystallized and the matrix is composed of microsparite. The marlstone in Cores 37 and 38, Section 1, form a third microfacies. They are highly argillaceous with radiolarian molds filled by chalcedony and/or calcite. Other biogenic components include Stomiosphaera, and rare foraminifers, aptychi, sponge spicules, and echinoid debris.

\section{Unit 7-Basalt (Cores 38, Section 2 through Core 40)}

This unit is black (N1), aphanitic basalt with calcite veins and disseminated pyrite in the upper $20 \mathrm{~cm}$. Altered angular clasts of the overlying sediment are incorporated in the upper $10 \mathrm{~cm}$ of the basalt. The basalt is vesicular, with fillings of celadonite(?) and glass. The overall appearance is sometimes massive and sometimes highly brecciated. The presence of two darker, more massive intervals and an abrupt appearance of vesicles indicates the possibilities of several flow units.

Three different types of basalt were recognized from the study of four thin sections on the basis of composition and texture. Type 1 and Type 3 are very similar in composition.

Type 1: Variolitic basalt with an intersertal groundmass texture (39-2):

This basalt is composed of $40 \%$ plagioclase, $30 \%$ augite, $15 \%$ magnetite, $3 \%$ olivine, and $12 \%$ glass. Laths of plagioclases (100 $\mu \mathrm{m}$ long) are randomly oriented. The extinction angle of the plagioclases suggests a composition of $\mathrm{An}_{30}-\mathrm{An}_{40}$. They are usually clear, some show sericitization and are replaced by epidote. The pyroxene is probably augite and is granular in shape. Magnetite has a cruciform skeletal and prismatic habit. Olivine is slightly altered and chloritized. Glass is locally altered into a mixture of palagonite, chlorite or celadonite(?), and carbonate.

Type 2: Vitric basalt (Sample 40-1, $141 \mathrm{~cm}$ ):

This basalt consists of $60 \%$ glass, $15 \%$ plagioclase, $15 \%$ augite, and $10 \%$ magnetite. Plagioclase and pyroxene form microphenocrysts which are intimately intergrown and form feathery aggregates. The glass is clear and magnetite forms cruciform skeletal crystals. Chalcedony fills some of the vesicles and fractures.

Type 3: Trachytic basalt:

This basalt is composed of $40 \%$ plagioclase, $35 \%$ glass, $15 \%$ magnetite, and $5 \%$ augite. The groundmass has a trachytic texture. Plagioclase has altered into a mixture of sericite and epidote and the glass has altered to palagonite. Magnetite has a skeletal cruciform habit. Augite was not observed, but some of the chlorite has crystallographic outlines, suggesting that it is replacing augite.

\section{Summary}

The most striking features of Site 367 sediments are: (1) almost continuous deposition from Upper Jurassic to Holocene; (2) cyclic character of sedimentation (Dean et al., this volume) and; (3) the similarity to the Mesozoic lithologic sequences in the western North Atlantic (Leg 11, Sites 99, 100, 101, and 105; Hollister, Ewing, et al., 1972; Lancelot et al., 1972), and the Mediterranean (Bernoulli, 1972), and to the outcrops exposed on Maio Island, Cape Verde islands (Stahlecker, 1934; Jansa et al., this volume).

The hole bottomed in altered basalt which contains several inclusions of sedimentary rocks. Age dates by $\mathrm{K}-\mathrm{Ar}$ methods of these basalts give minimum ages of 88 to 92 m.y. (Duncan and Jackson, this volume). The sediment above the basalt shows slight recrystallization; however, there are no indications of strong thermal alteration.

The basalt is overlain by an Upper Jurassic reddish brown limestone sequence in which radiolarian, filimentous, and Saccocoma-aptychi microfacies are recognized, all characteristic of pelagic facies of the Tethyan Mesozoic. Pelagic lamellibranch and radiolarian limestone typically occur in the Middle Jurassic of the Apennines (Bernoulli, 1972), and the Saccocomaaptychi microfacies is typically found in the Kimmeridgian of the same region (Jansa et al., this volume).

The sedimentary structures in the marl and limestone of unit 6 are more variable than those that occur in the overlying units. Horizontal and inclined laminations, small-scale scouring, and small-scale slump features are common. These, together with the occurrence of thin layers of intraclast breccia, indicate that during the Middle to Late Jurassic, hydrodynamic conditions were more variable than occurred later. This variability can be explained by slightly shallower water depth, by a more variable current regime, local tectonic disturbances, or greater irregularity of bottom topography. 
A substantial change in sediment composition occurs around the Lower to Upper Cretaceous boundary ( 844 to $890 \mathrm{~m}$; Cores 24 and 25). Sediments below this boundary are mostly carbonate but, above the boundary, terrigenous material is the dominant component.

Lower Cretaceous limestone is overlain by late Aptian-early Albian to early Turonian black shale which has an organic carbon content of up to $28 \%$. The high organic content of the shale is interpreted to be in part the result of a large influx of terrigenous organic debris into the basin (Gardner et al., this volume). Reducing conditions favored the formation of the pyrite and iron monosulfides. The black shale lacks visible bioturbation. The predominantly black color of the sediments, however, could obscure burrows.

The Upper Cretaceous multicolored hemipelagic silty clay, which overlies the black shale, is composed mostly of terrigenous material. The conditions which led to the alteration of oxygenated and reduced environments within the sediments (as evidenced by the multicolors) are interpreted to be the result of fluctuating input of organic debris (Dean et al., this volume; Gardner et al., this volume). The Eocene zeolitic clay which overlies the hemipelagic clay does not contain substantial coarse grained terrigenous components and we consider this to be a pelagic deposit.

\section{GEOCHEMICAL MEASUREMENTS}

The introduction to this volume outlines the geochemical techniques used aboard ship for each of the parameters discussed below.

\section{Organic Carbon}

Table 3 summarizes the shipboard determinations and a few shore based analyses (Texas A\&M University and Shell Oil Company) of organic carbon content and organic carbon to total nitrogen $(\mathrm{C} / \mathrm{N})$ ratios. Duplicate analyses were run on Core 1, Section 5, 144$150 \mathrm{~cm}$, following squeezing for interstitial water. Agreement was within one standard deviation for both organic carbon and $\mathrm{C} / \mathrm{N}$. Samples were taken in adjacent facies in cores with laminated sediments, and often showed marked differences in organic carbon content. The highest organic content $(30 \%)$ is in a thin layer with plant debris in Core 26, Section 4, 28-29 cm. Core 19, Section $4,0 \mathrm{~cm}$, has an organic carbon content of $6.7 \%$ with a $\mathrm{C} / \mathrm{N}$ of 30.6 This section had the highest methane concentration, $96.5 \%$, in the interstitial gas. Organic carbon and $\mathrm{C} / \mathrm{N}$ values are scattered because of the alternating organic-rich and organic-poor facies. Organic carbon values range from $0.05 \%$ to $0.3 \%$ with low $\mathrm{C} / \mathrm{N}$ values for the organic-poor facies but greater than $0.5 \%$ organic carbon and $\mathrm{C} / \mathrm{N}$ ratios greater than 10 in the organic-rich sediments.

Additional samples from Cores 18 to 22 were taken from the working half of the split core three months after the cruise. These samples had much higher organic carbon contents than adjacent samples taken onboard. Samples analyzed by Scripps Institution of Oceanography (SIO) were also high in this region.
TABLE 3

Results of Carbon and Nitrogen Analyses From Site 367

\begin{tabular}{|c|c|c|c|c|c|c|}
\hline \multirow{2}{*}{$\begin{array}{c}\text { Sample } \\
\text { (Interval in } \mathrm{cm} \text { ) }\end{array}$} & \multirow{2}{*}{$\begin{array}{l}\text { Depth } \\
(\mathrm{m})\end{array}$} & \multicolumn{2}{|c|}{$\begin{array}{c}\text { \% Organic C } \\
\text { (total dry wt. basis) }\end{array}$} & \multicolumn{2}{|c|}{$\begin{array}{c}\mathrm{C} / \mathrm{N} \\
\text { (atomic ratio) }\end{array}$} & \multirow[b]{2}{*}{ Remarks } \\
\hline & & $x$ & SD & $x$ & SD & \\
\hline $1-5,144-150$ & 6 & 0.582 & 0.012 & 10.1 & 0.17 & \\
\hline $1-5,144-150$ & 6 & 0.570 & 0.006 & 10.1 & 0.13 & \\
\hline $2-1,83-84$ & 8 & 1.132 & 0.045 & 16.4 & 0.72 & Clay \\
\hline $2-2,62-63$ & 8 & 0.351 & 0.027 & 8.2 & 1.04 & Clay \\
\hline $4-3,120-150$ & 68 & 0.225 & 0.025 & 7.5 & 0.37 & \\
\hline $8-3,130-150$ & 310 & 0.205 & 0.008 & 4.6 & 0.45 & \\
\hline $8-4,46-48$ & 311 & 0.335 & 0.033 & 5.8 & 0.09 & Clay \\
\hline $8-4,50-52$ & 311 & 2.590 & 0.058 & 13.1 & 0.11 & Black clay \\
\hline $14-4,41-42$ & 387 & 0.093 & 0.008 & 6.9 & 2.80 & Clay \\
\hline $14-4,51-52$ & 387 & 0.131 & 0.032 & 6.5 & 3.52 & Clay \\
\hline $15-3,130$ & 480 & 0.154 & 0.030 & 4.8 & 1.45 & Silty clay \\
\hline $15-4,91-92$ & 481 & 0.172 & 0.042 & 5.7 & 1.03 & Silty clay \\
\hline $15-4,105-106$ & 481 & 0.099 & 0.075 & 4.2 & 0.26 & Silty clay \\
\hline $17-4,115-116$ & 625 & 0.139 & 0.006 & 3.7 & 0.42 & \\
\hline $17-4,118-119$ & 625 & 3.897 & 0.105 & 28.1 & 0.37 & \\
\hline $18-2,144-145$ & 640 & 37.21 & & 44.7 & & TAMU \\
\hline $19-4,0-1$ & 653 & 6.699 & 0.569 & 30.5 & 2.86 & Black shale \\
\hline $19-4,20-25$ & 653 & 4.09 & & & & LECO-Shell \\
\hline $19-4,44-45$ & 653 & 18.54 & & 34.1 & & TAMU \\
\hline $20-2,7-8$ & 688 & 16.29 & & 25.4 & & TAMU \\
\hline $22-5,104-105$ & 728 & 21.06 & & 23.8 & & TAMU \\
\hline $25-3,38-39$ & 898 & 3.988 & 0.004 & 25.7 & 1.02 & Dark band \\
\hline $25-3,42-43$ & 898 & 0.139 & 0.005 & 8.6 & 2.77 & Limestone \\
\hline $26-4,28-39$ & 919 & 25.070 & 1.086 & 18.5 & 1.65 & Plant debris \\
\hline $31-2,37-38$ & 1062 & 0.521 & 0.015 & 31.5 & 2.83 & $\begin{array}{l}\text { Argillaceous } \\
\text { limestone }\end{array}$ \\
\hline $32-5,97-98$ & 1090 & 0.046 & 0.006 & 2.0 & 0.55 & $\begin{array}{l}\text { Argillaceous } \\
\text { limestone }\end{array}$ \\
\hline $33-3,92-93$ & 1110 & 0.052 & 0.002 & 2.1 & 0.28 & Shale \\
\hline $33-3,93-94$ & 1110 & 0.034 & 0.011 & 2.0 & 0.47 & $\begin{array}{l}\text { Siliceous } \\
\text { Limestone }\end{array}$ \\
\hline
\end{tabular}

These, like the additional samples, were not kept frozen prior to analysis. The reason for this difference is not clear, but additional studies are in progress. No apparent contamination was observed.

\section{Interstitial Gas}

Evidence of gas was present beginning with Core 17 (625 m subbottom) as gas bubble formation within the core as well as bulging end caps on the core liner. Gas samples were taken through the core lines or through end caps. The results are given in Table 4. Hydrocarbons above propane were not detected.

\section{Carbonate Bomb Measurements}

The routine carbonate measurements are tabulated in Table 5.

\section{Interstitial Water Chemistry}

Table 6 lists and Figure 7 plots the results of interstitial water from squeezed samples. No interstitial water samples were taken below Core 23, Section 1, $144-150 \mathrm{~cm}$, because deeper sediment was too consolidated to liberate any water.

\section{Basalt Geochemistry}

A sample of basalt from Core 39, Section 2, 28-29 $\mathrm{cm}$, was washed, dried, and powdered, then analyzed for water and carbonate content. This sample was chosen for its homogeneity and lack of visible calcite veins. Analyses for $\mathrm{H}_{2} \mathrm{O}$ and $\mathrm{CO}_{2}$ were made with Hewlett-Packard $\mathrm{CHN}$ analyzer. Water content was $3.8 \%$. Carbonate content was $0.96 \%$ as calcium carbonate. The standard used is a powdered basalt having $3.0 \% \mathrm{H}_{2} \mathrm{O}$ and $1.6 \% \mathrm{CaCO}_{3}$. 
TABLE 4

Results of Interstitial Gas Analyses From Site 367

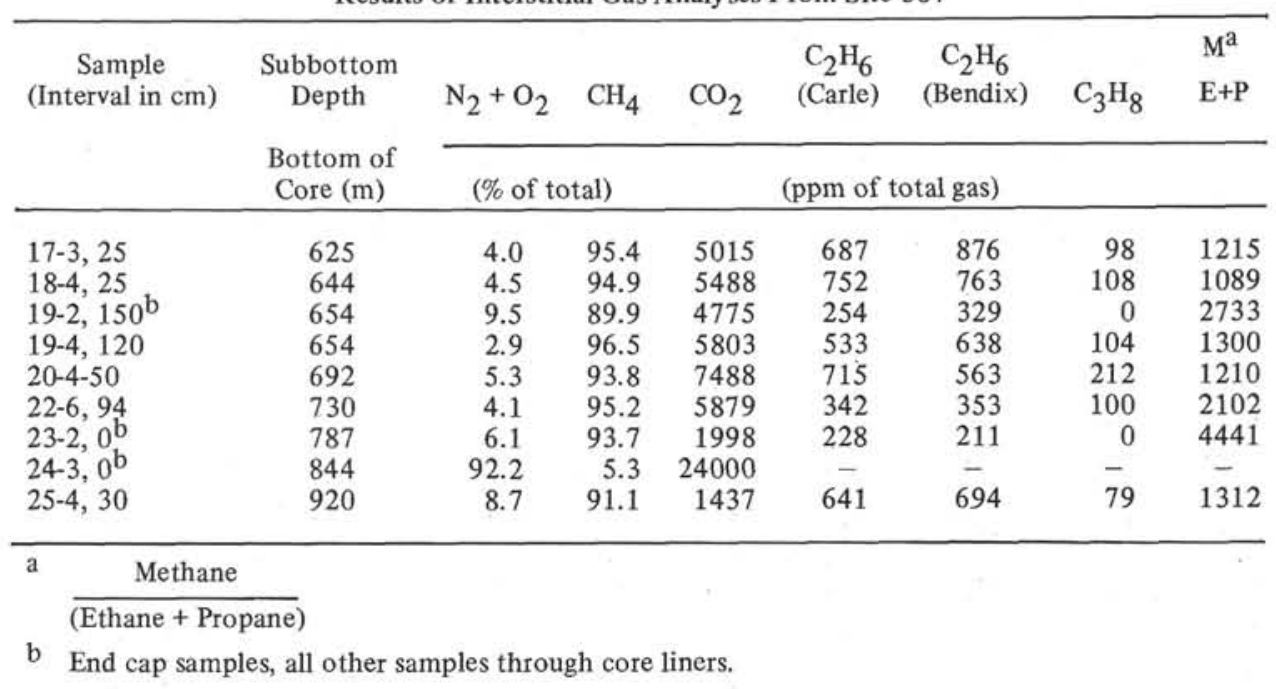

TABLE 5

\% CaCO3 - Carbonate Bomb Method Leg 41 Site 367

\begin{tabular}{lrrl}
\hline $\begin{array}{c}\text { Sample } \\
\text { (Interval in cm) }\end{array}$ & $\begin{array}{c}\text { Depth } \\
(\mathrm{m})\end{array}$ & $\% \mathrm{CaCO}_{3}$ & \multicolumn{1}{c}{ Lithology } \\
\hline $1-5,49-50$ & 7 & 41 & Nannofossil marl \\
$2-2,63-64$ & 10 & 42 & Nannofossil ooze \\
$4-2,56-57$ & 66 & 69 & Nannofossil marl \\
$14-3,122-123$ & 386 & 0 & Zeolitic clay \\
$15-3,63-64$ & 477 & 0 & Clayey sand \\
$16-3,110-111$ & 543 & 0 & Porcellinite \\
$17-3,73-74$ & 620 & 0 & Clay \\
$18-3,94-95$ & 641 & 0 & Shale \\
$21-3,45-46$ & 695 & 34 & Black shale \\
$23-2,70-71$ & 786 & 0 & Clay \\
$24-2,124-125$ & 842 & 0 & Claystone \\
$24-3,47-48$ & 843 & 0 & Claystone \\
$25-3,91-92$ & 895 & 94 & Limestone \\
$27-3,84-85$ & 943 & 92 & Limestone \\
$29-2,40-41$ & 998 & 97 & Limestone with chert \\
$29-2,106-107$ & 999 & 96 & Limestone \\
$30-2,141-142$ & 1028 & 92 & Limestone \\
$32-3,133-134$ & 1087 & 58 & Limestone \\
$33-1,67-68$ & 1108 & 78 & Clay \\
$34-2,50-51$ & 1113 & 91 & Limestone \\
$35-3,86-88$ & 1120 & 80 & Limestone \\
$36-3,63-64$ & 1130 & 51 & Argillaceous limestone \\
\hline & & & \\
\hline
\end{tabular}

\section{PHYSICAL PROPERTIES}

Four major lithologic units at Site 367 are distinctly correlatable with the physical properties data. (See Trabant, this volume for tabulation of data.)

\section{Bulk Properties}

Bulk property measurements were made for water content, void ratio, bulk density, porosity, and specific gravity. Bulk properties are interrelated so only porosity is shown in the graphical presentation. The plot of porosity versus depth (Figure 8) shows a linear trend, with a good grouping of the values from within the lower limestone unit where the porosities are less than $30 \%$. The dashed line separates limestone from the overlying clay and shale. Large variability occurs between adjacent limestone samples only a few centimeters apart because certain limestones are "cleaner" or "purer" than others. The "cleaner" limestones are less porous than the "dirtier" ones.

\section{Shear Strength}

Due to the limited number of cores retrieved within the uppermost 250 meters of the section, shear strengths were obtained only on two cores.

TABLE 6

Results of Interstitial Water Analyses From Site 367

\begin{tabular}{|c|c|c|c|c|c|c|c|c|}
\hline $\begin{array}{c}\text { Sample } \\
\text { (Interval in } \mathrm{cm} \text { ) }\end{array}$ & $\begin{array}{l}\text { Subdepth } \\
\text { (m) }\end{array}$ & $p \mathrm{H}$ & $\begin{array}{l}\text { Alkalinity } \\
(\mathrm{meq} / \mathrm{kg})\end{array}$ & $\begin{array}{c}\text { Salinity } \\
(\%)\end{array}$ & $\begin{array}{c}\mathrm{Ca}^{++} \\
(\mathrm{mmoles} / \mathrm{l})\end{array}$ & $\begin{array}{c}\mathrm{Mg}^{++} \\
(\mathrm{mmoles} / \mathrm{l})\end{array}$ & $\begin{array}{c}\mathrm{Cl}^{-} \\
(\%)\end{array}$ & Remarks \\
\hline $1-5,144-150$ & 7.5 & 7.46 & 4.68 & 34.9 & 11.29 & 52.37 & 19.27 & \\
\hline $4-4,144-150$ & 69.5 & 7.38 & 3.46 & 34.9 & 8.85 & 51.42 & 19.27 & \\
\hline $8-4,144-150$ & 308.5 & 7.20 & 8.91 & 33.6 & 14.53 & 46.03 & 19.27 & \\
\hline $14-2,144-150$ & 381.5 & 7.40 & 3.32 & 32.4 & 18.09 & 42.62 & 19.27 & Disturbed \\
\hline $15-4,144-150$ & 479.5 & 7.74 & 3.05 & 33.0 & 23.60 & 43.38 & 18.97 & Disturbed \\
\hline $16-5,140-150$ & 547.5 & - & 2.27 & 30.2 & 25.57 & 38.09 & 17.60 & \\
\hline $18-3,140-150$ & 640.5 & 7.01 & 2.52 & 32.2 & 29.55 & 39.34 & 18.97 & \\
\hline $21-4,144-150$ & 698.0 & 7.01 & 2.30 & 32.2 & 37.44 & 31.82 & 19.31 & \\
\hline $23-1,140-150$ & 779.0 & 7.48 & 1.29 & 32.4 & 46.08 & 36.29 & 18.91 & Disturbed \\
\hline
\end{tabular}



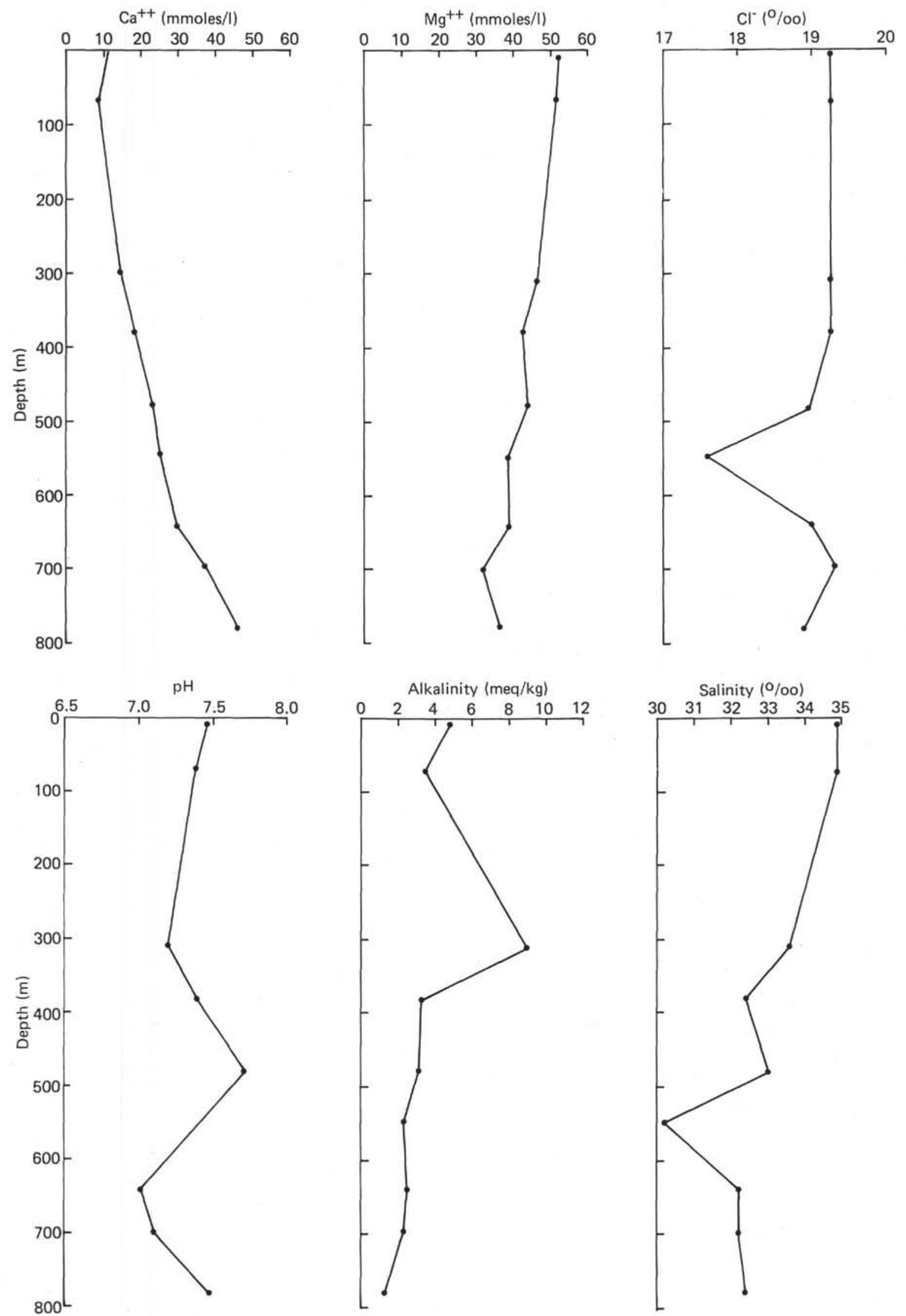

Figure 7. Plots of interstitial water analyses from Site 367. 


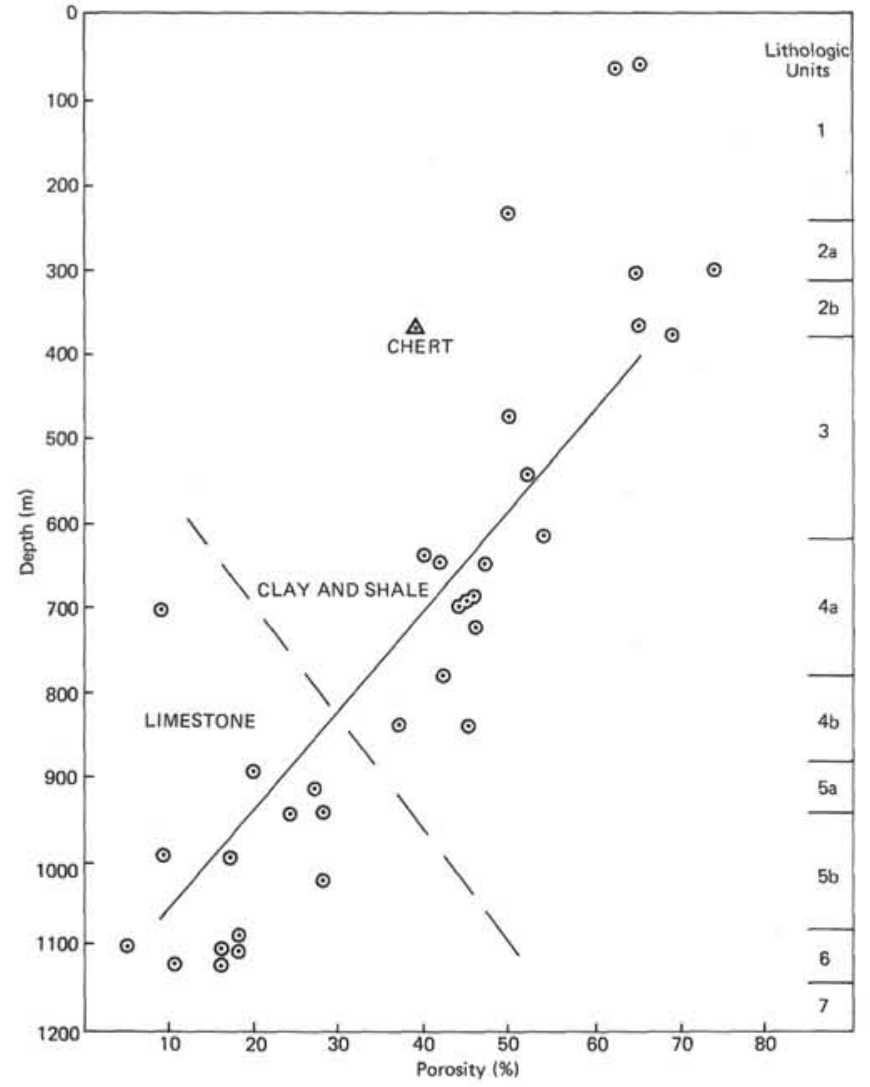

Figure 8. Plot of porosity versus depth in Site 367. The solid line is a general regression line of the data and the dashed line separates limestone samples from clay and shale samples.

\section{Acoustic Velocities}

The compressional velocity (Vp) was measured using the Hamilton Frame velocimeter. These values are highly variable, ranging from $1.56 \mathrm{~km} / \mathrm{sec}$ within the uppermost, soft, unconsolidated clay to $4.75 \mathrm{~km} / \mathrm{sec}$ in the lowermost clayey limestone unit. The velocity data are plotted in Figure 9.

Velocities measured in the horizontal direction generally are higher than those in the vertical direction. The visual homogeneity of the limestone can be correlated to the velocities. The more laminated or "dirty" the limestone, the lower the velocity, with difference extremes ranging up to $1.0 \mathrm{~km} / \mathrm{sec}$. The wide scatter obtained within this limestone-marlstone unit is apparent in Figure 9. A velocity of $4.26 \mathrm{~km} / \mathrm{sec}$ was obtained within the homogenous fine-grained basalt of lithologic Unit 7.

\section{Summary}

Although the lithologies at Site 367 may be subdivided into over a half dozen units, only four major geotechnic units can be recognized.

Unit 1: A silty clay unit $(0$ to $625 \mathrm{~m}$ which corresponds to lithologic Units 1, 2, and 3) composed of nannofossil foraminifer marl and clay, diatomaceous clay, zeolitic clay with a few cherts (see porosity value at $373 \mathrm{~m}$ ), and a multicolored variegated silty clay. This sequence reflects a transition from unconsol-

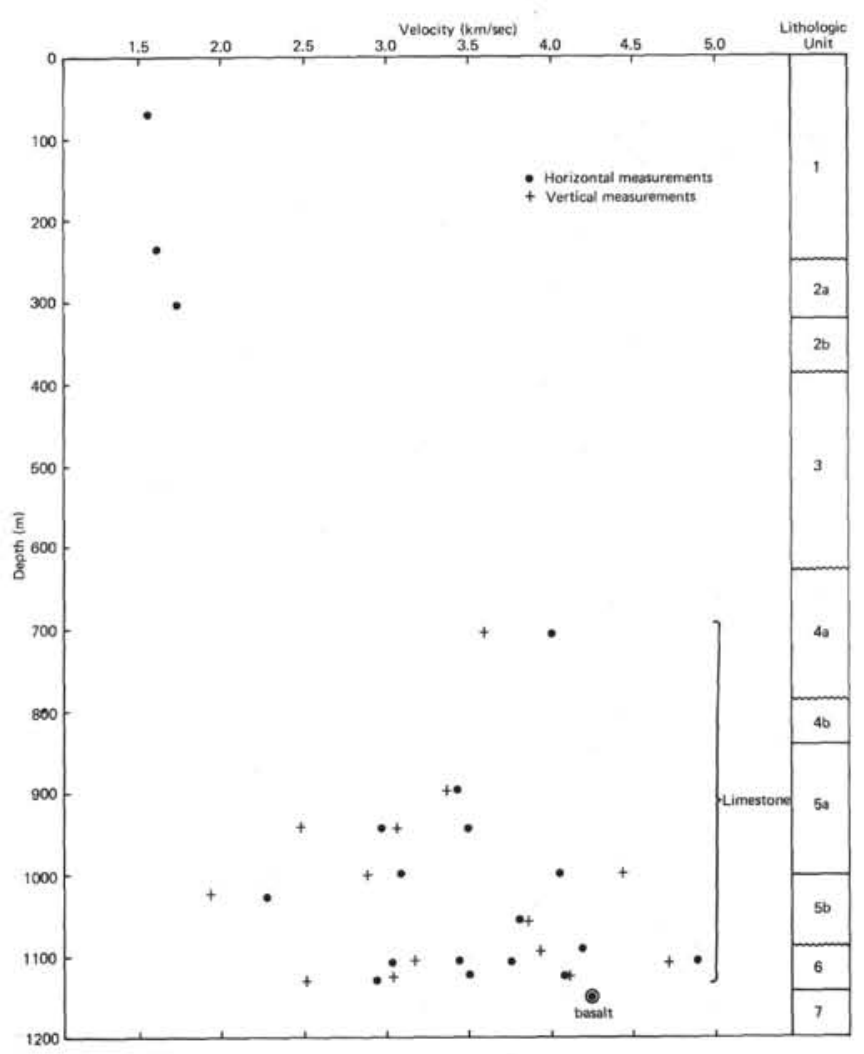

Figure 9. Plot of sound velocity versus depth in Site 367.

idated to well-indurated silty clay with $\mathrm{Vp}$ values below $2.0 \mathrm{~km} / \mathrm{sec}$.

Unit 2: A gassy shale and mudstone zone which has a few intercalated limestones. Velocities are too attenuated to be measured due to the presence of gas. The relative percentage of the intercalated limestone in this sequence increases towards the base, where the unit becomes entirely limestone. Porosity values within the shales are meaningless due to the presence of gas. The specific gravity values, however, strongly reflect the large amount of organic matter with values as low as $1.65 \mathrm{~g} / \mathrm{cc}$.

Unit 3: This unit consists of a large variety of limestones which exhibit variations in the physical properties according to their carbonate content.

Unit 4: The basalt recovered at the base of the hole was measured only for $\mathrm{Vp}$ and specific gravity. Calcite veins are present, although their effects on the acoustic velocities were not determined.

\section{BIOSTRATIGRAPHIC SUMMARY}

Sediments from Site 367 range in age from Quaternary to Upper Jurassic. Preservation of the material is generally moderate to poor. Coring was continuous only between Cores 9 and 14 and between Cores 33 and 40 . The combination of these two factors, discontinuous coring and poor fossil content and preservation, resulted in much uncertainty in identifying the presence or absence of hiatuses or discontinuities.

The early Aptian to Late Jurassic section contains abundant nannofossils but only scattered occurrences and abundances of calcareous and agglutinated benthic 
foraminifers and radiolarians. Ostracode casts, aptychi, Saccocoma sp., pelagic pelecypods, Tintinnids, and ammonites occur intermittently. The predominance of nannoplankton, high diversity of calcareous fossils and presence of aptychi suggests these sediments belong to a deep-water facies.

Faunas and floras of Eocene to upper Paleocene age show a domination by radiolarians, with poor assemblages or absence of planktonic foraminifers and nannofossils. These observations, together with the composition of the benthic foraminifers, suggest that the sediments accumulated in a bathyal environment with fluctuating rates of carbonate dissolution.

\section{Foraminifers}

Planktonic and benthic foraminifers range in age from Pleistocene to Upper Jurassic.

\section{Cenozoic}

The Pleistocene is represented by the Globorotalia truncatulinoides Zone in Cores 1 and 2. A Pleistocene age not younger than 80,000 years B.P. is indicated by the presence of Globorotalia tumida flexuosa. Cores 3 through 5 contain a Pliocene microfauna, which includes: Globorotalia exilis, G.cf. tosaensis, G. miocenica, G. multicamerata, Globorotalia cf. margaritae, Sphaeroidinella dehiscens, Globorotalia crassaformis Gr. Tumida, Globigerinoides conglobatus, Globigerina rubescens, and $G$. digitata. These species are accompanied by reworked Miocene foraminifers. The core catcher of Core 6 contains a mixed planktonic foraminifer fauna, the youngest elements of which are Globigerinoides trilobus, Cassigerinella chipolensis and Globigerina angustiumbilicata, indicating an age not younger than middle/lower Miocene. The bulk of planktonic foraminifers are of Oligocene age. They include Globigerina ciperoensis, G. ouachitaensis, $G$. praebulloides. Eocene species Globorotalia subbotinae and Acarinina sp. are present, and also a Cretaceous species, Hastigerinoides sp., was found. Benthic foraminifers include representatives of different ecological groups; shallow water inhabitants, such as Ammonia beccarii, Elphidium crispum, and Amphistegina are mixed with deep dwellers such as Melonis, Pyrgo, Virgulina, Pullenia, Ehrenbergina, Cassidulina, Florilus, Planulina, Dentalina, Fissurina, Dorothia, and Uvigerina. Preservation of the foraminifers is good to moderate. Core catchers 7 through 9 contain either no stratigraphically significant foraminifers or are totally barren of foraminifers. Middle Eocene planktonic foraminifers are rare to few and poorly preserved. Core 10 contains a single specimen of Acarina, indicating an age not younger than middle Eocene. Core 11 has an assemblage which suggests a middle Eocene age. Core 12 is given an age of early Eocene. Benthic foraminifers are calcareous deepwater species such as Pleurostomella, Cibicides, Bulimina, Aragonia, Gyroidina, Lentinculina. Cores 13 and 14 are barren of foraminifers.

\section{Mesozoic}

Cores 15 through 18 contain specific Upper Cretacous assemblages which are typical of the flysch and the noncalcareous shale facies of the Alps with primitive and higher developed agglutinated benthic foraminifers. The only calcareous foraminifer found is Gyroidina. The only fauna recovered in Cores 15, 17, and 18 include Hedbergella planispira, $H$. infracretacea, $H$. cf. Amabilis, Heterohelix sp., and Loeblichella sp. They suggest only a Late Cretaceous age. The foraminifer faunas are accompanied by fish debris and Bryozoa, the last of which indicates admixtures from shallower water depths into the bathyal sedimentation regime. Planktonic foraminifers of Cores 19 through 21 indicate a Cenomanian age. They are small and have abundances ranging from abundant to rare. The following taxa were determined: Hedbergella delrioensis, $H$. trochoidea, $H$. infracretacea, $H$. amabilis, H. globigerinelloides, Globigerinelloides caseyi, Guembelitria harrisi, and Heterohelix moremani. In Samples 367-19-3, 138-140 cm, one specimen of Praeglobotruncana was found. In Samples 367-21-6, 35$36 \mathrm{~cm}$, and 21, CC, some specimens of Schackoina cenomana and Hedbergella brittonensis were found. Fish debris is common but benthic foraminifers are extremely rare. Core catcher 22 contains an Albian fauna of Ticinella primula, Hedbergella amabilis, $H$. planispira, $H$. infracretacea, $H$. delrioensis, $H$. simplicissima, Clavihedbergella simplex and Globigerinelloides sp. The preservation of planktonic foraminifers is moderate. The benthic foraminifer faunas are rare and fish debris is common. Core 23 is barren of foraminifers. Core catcher 24 contains a small-sized but abundant and well-preserved planktonic foraminifer fauna. The assemblage includes Hedbergella aff. kugleri, $H$. aff. graysonensis, $H$. infracretacea, H. globigerinelloides, Globigerinelloides sp., Gubkinella sp. sp., and very small Hedbergella specimens. We have assigned a lower Aptian to Barremian age to this assemblage. Benthic components of the foraminifer fauna include various agglutinated forms and some Lagenids. This assemblage suggests conditions perhaps similar to those of the overlying Albian and Cenomanian sequence (Cores 19 through $22)$; a deep-water environment with restricted circulation. Cores 25 and 26 contain only a rare benthic fauna with poor preservation. A Neocomian age is based on a comparison with Leg 11, Site 105, where similar faunas occur (Luterbacher, 1972). Foraminifers are missing in Sample 27, CC. Samples from Core 28, Section 6, are characterized by the same assemblage of benthic foraminifers as occurs in Cores 25 and 26. Specimens of Dorothia praehauteriviana are common, which were assigned a ?Valanginian age on Leg 11 (Luterbacher, 1972). The higher proportions of calcareous benthic foraminifers in comparison to the faunas of the overlying black shales suggest a paleoenvironment influenced by better circulation patterns. Cores 29 through 31 are barren of foraminifers. Core 32 has an assemblage of planktonic foraminifers consisting of Spirillina sp. sp., Lentinculina, Nodosaria, Spirophthalmidium, and Rhabdammina. Cores 33 and 34 are barren of foraminifers. Cores 35 through 37 contain the same faunas as Core 32. The fauna indicates an upper Jurassic age. 


\section{Calcareous Nannoplankton}

The preservation of coccoliths varies from poor to good. Three stratigraphic intervals are identified: (1) the Pleistocene to middle Miocene (Cores 1 to 6); (2) the upper lower Eocene (Cores 12 to 13); and (3) the Cretaceous to Upper Jurassic (Cores 16 to 38 ). The results from the upper part of the site (Cores 1 to 17) are based mostly on investigations of core catchers, but in the lower part of this site (Cores 18 to 38) results are based on identification of coccoliths from samples of the core sections.

\section{Cenozoic}

Pleistocene floras were recovered in the uppermost cores (Cores 1 and 2). Coccoliths are abundant and well preserved. Both cores belong to the Gephyrocapsa oceanica or Emiliania huxleyi zones. The Emiliania ovata Subzone was not observed. The subzone may be present in this section but the 36.5 meter uncored interval lies between Core 2 and Core 3. The preservation in Core 1 is better than in Core 2. The central bridges of the species Gephyrocapsa oceanica are not always observed in this core indicating the coccoliths are partially dissolved. Also some contamination of middle Miocene to upper Pliocene species is seen. Pliocene coccoliths are found in Cores 3 through 5. Core 3 is the Discoaster surculus Subzone. Common and generally well preserved Pliocene coccolith assemblages occur in Core 4 indicating the Discoaster tamalis Subzone. The samples are rich in discoasters, especially $D$. pentaradiatus, which indicate warm waters, but many of them are broken. No significant overgrowth was observed. Dissolution of coccoliths, but not of discoasters, was observed in Core 5. Some middle to upper Miocene and Eocene contamination was found. The assemblages in Core 6 are not older than middle Miocene. The age probably correlates to the middle Miocene Sphenolithus heteromorphus Zone, based on the presence of Discoaster challengeri, Discoaster braarudii, Discoaster exilis, Helicopontosphaera kamptneri, Discolithina vigintiforata, and Spenolithus heteromorphus. Some reworked Paleogene species were noted. No significant overgrowth was observed, but discoasters and most coccoliths are partially dissolved. Coccoliths are practially absent in all core catchers of Cores 7 to 11 . In Samples 7, CC, 10, CC, and 11, CC only, one to three coccolith specimens were observed and these probably result from contamination although they may reflect a very bad state of preservation. The core catcher of Core 12 contains common and moderately dissolved specimens assigned to the lower Eocene Discoaster lodoensis Zone, based on Coccolithus crassus and D. lodoensis. An upper lower Eocene assemblage of rare and poorly preserved coccoliths is found in Core 13 . Coccoliths are practically absent in Cores 14 to 17 . Several partially dissolved coccoliths were seen, however, they are mostly contamination.

\section{Mesozoic}

The first Cretaceous coccolith (Tetralithus obscurus) appears in Core 16, and is not older than Santonian age. Cores 16 , Sections 6 through 18 , are of Coniacian age. Cores 19 through 22, Section 5, are late Albian to early Turnonian in age. The assemblage for this part of the Cretaceous includes Vagalapilla matalosa, Tetralithus obscurus, Eiffellithus turriseiffeli, Lithastrinus floralis, Corollithion signum, and Chiastozygus amphipons. Coccoliths are rare to abundant, and preservation is generally poor to moderate. Early Cretaceous coccoliths are found in Sample 22, CC through Core 32, Section 3. Coccoliths of late Aptian to early Albian age are found in Sample 22, CC through Core 25, Section 1, 6-7 cm. The species include: Parhabdolithus angustus and Lithastrinus floralis. The abundance and preservation of species in Core 24 is better than in Cores 22 and 23. Early Aptian assemblages of coccoliths were observed only in Sample 25-1, $16-17 \mathrm{~cm}$ through Core 25 , Section 3 . A relatively good coccolith assemblage of Barremian age is found in Core 5 , Section 4 and in Core 26. The upper boundary of the Barremian is dominated by the last occurrence of Nannoconus colomii. The coccoliths are well preserved and common to abundant. A Valanginian and Hauterivian assemblage is present in Cores 27 through 30 , Section 1. The upper limit is defined by the last occurrence of Cruciellipsis cuvillieri, which has a known range from early Berriasian to Hauterivian (Thierstein, 1971). The lower boundary (base of Hauterivian) is the first occurrence of Diadorhombus rectus. The preservation of the coccolith assemblages is poor to moderate and the abundance is few to common. The base of the Cretaceous is represented by the Berriasian in Core 30, Section 2 through Core 32, Section 3. The lower boundary of the Cretaceous is characterized by the first occurrence of Lithraphidites carniolensis, Nannoconus colomii, and Cruciellipsis cuvillieri. The coccoliths are few to common with poor to moderate preservation. Core 32, Sections 4 and 5, belong to the Tithonian. This stratigraphic level is based on the presence of Parhabdolithus embergeri and the absence of Lithraphidites carniolensis, Nannoconus colomii, and Cruciellipsis cuvillieri. The coccoliths are common with moderate preservation. According to the zonation of Barnard and Hay (1974) this stratigraphical level belongs not to the Tithonian but to the late Kimmeridgian Parhabdolithus embergeri Zone. We use the nomenclature used by Wilcoxon (1972) for DSDP Leg 11 , Site 105, giving us the advantage of possible correlation of the two sites. The coccoliths of Cores 32, Section 5, through 38 are rare to few and poorly preserved. The assemblage of coccoliths includes Cyclagelosphaera margareli and Callolithus martelae. Both species first appear in the Oxfordian (Bukry and Bramlette, 1969).

\section{Radiolarians}

Radiolarians are present within three stratigraphic intervals: the upper Pleistocene, the upper and lower Eocene, and the Lower Cretaceous. The Pleistocene and Eocene sections contain sufficiently well preserved assemblages to allow approximate age assignments to be made. Radiolarians in the Lower Cretaceous sections are rare, poorly preserved, and fragmented. The siliceous skeletal material has generally been 
replaced by pyrite or calcite. Reliable age assignments for the Mesozoic samples were not possible because of the poor preservation of most of the fragments.

\section{Cenozoic}

Core 1 contains rare specimens of moderately well preserved radiolarians indicative of a Pleistocene age. These taxa include Ommatartus tetrathalamus, Lamprocyclas maritalis polypora, Siphocampe corbula, Axoprunum angelinum, and Pterocanium trilobum. The presence of $A$. angelinum in Sample 1, CC suggests an age greater than $0.4 \mathrm{~m} . \mathrm{y}$. The base of the Pleistocene was not identified because Cores 2 through 7 were devoid of radiolarians. Scattered middle and early Tertiary forms, Calocycletta virginis, Cannartus laticonus, Stichocorys delmontensis, and Rhopalocanium sp., are included with the Pleistocene species. The presence of reworked contaminants is not surprising in view of the physiographic location of this site. Outcrops of Tertiary strata along the adjacent continental margin are a likely source for such material. Core 8 contains common specimens of moderately preserved radiolarians diagnostic of the upper Eocene Thyrsocyrtis bromia Zone. Core 9 contains scattered fragments of upper Eocene taxa, but there are insufficient specimens present for a reliable age assignment. Core 10 contains rare and very poorly preserved fragments of lower and middle Eocene species consistent with an age corresponding to the Theocampe mongolifieri or $T$. cryptocephala cryptocephala zones. Core 12 contains a rare and poorly preserved assemblage which corresponds to the lower Eocene Phormocyrtis striata striata Zone or Buryella clinata Zone. Core 13 is devoid of identifiable radiolarians. Core 14 can be assigned to the Bekoma bidartensis Zone of lowermost Eocene or uppermost Paleocene age, based on common but poorly preserved specimens of Buryella tetradica, Lophocyrtis biaurita, Phormocyrtis turgida, Thecosphaerella rotunda, Lithocyclia archaea, and Stylosphaera coronata sabaca. Radiolarians are absent in the Paleogene sediments below Core 14. There is no evidence of reworking or redeposition in any of the Eocene radiolarian assemblages, although the abundance of the diagnostic forms is not sufficient to rule out the possibility of reworking.

\section{Mesozoic}

Poorly preserved radiolarian fragments were identified in several samples which range in age from the Cretaceous through Upper Jurassic. Virtually all radiolarian fragments have experienced diagenesis, with silica replaced either by pyrite or calcite. Radiolarian fragments in the varicolored siltstones and mudstones were almost exclusively replaced by pyrite. Scattered radiolarian fragments were also present in washed samples and in thin sections from the lithified white limestone units. Most of these forms were totally replaced by calcite, with details of the original test morphology obliterated. Mesozoic radiolarians in the nonsilicified sediments examined from Cores 15 through 28 are either absent or altered to pyrite.

The pyritized radiolarians are generally too poor to attempt any age assignments. The exceptions are
Sample 26, CC which, on the basis of the presence of Lithocampe elegantissima and the general aspect of the fauna, is considered Albian-Aptian, and Core 28, Section 2, 44-54 cm, which is Neocomian based on the presence of a member of the Sphaerostylus lanceola group. Siliceous radiolarians from Cores 28 to 32 are too poor or too sparse to indicate anything but a broad Neocomian to Late Jurassic age. One exception is Core 29, Section 2, 26-27 cm, which contains Sethocapsa cetia and $S$. trachyostraca representing the Sethocapsa trachyostraca Zone. Samples from Cores 34 to 37 contained more abundant, slightly better preserved radiolarians but, because radiolarians in the Late Jurassic are not well enough known, the age assignments are based on foraminifer and nannofossil data.

\section{ACCUMULATION RATES}

The computation of Neogene accumulation rates follows the same time scales used for Site 366 (this volume). The Cretaceous and Jurassic time scales have been adapted from Berger and von Rad (1972) and van Hinte $(1972,1976)$. The stratigraphic dates given are based on foraminifers, nannofossils, and radiolarians, as well as calpionellids and ammonites for one sample at the Jurassic/Cretaceous boundary. No attempt has been made in our calculations to correct for compaction. Only crude estimates can be given for accumulation rates, due to spot coring in most parts of the site, and to poor faunal preservation, abundance, and diversity.

The Pleistocene and Pliocene are characterized by high accumulation rates (Figure 10) as shown by large amounts of redeposited faunal components. Miocene and Oligocene accumulation rates are difficult to estimate because sufficient data are lacking. However, if gaps are present, they cannot exceed values of 11 $\mathrm{m} / \mathrm{m}$.y. for upper Miocene and $2.3 \mathrm{~m} / \mathrm{m}$.y. for Oligocene and lower Miocene. Accumulation rates during the Eocene are 6 to $7 \mathrm{~m} / \mathrm{m}$.y., which is lower than that of the Eocene at Site 366, Core 14 (rise). Age dates are insufficient for the Paleogene and part of the Upper Cretaceous. It is impossible to decide whether there are gaps or not in this section, because of intermittent coring. Accumulation rates for Cenomanian to Aptian black shale are about $20 \mathrm{~m} / \mathrm{m}$.y. The Early Cretaceous variegated claystone and upper parts of the white and dark limestone, have accumulation rates of 12.y $\mathrm{m} / \mathrm{m} . \mathrm{y}$. The chert-bearing parts of the lower Neocomian show values of about $4.8 \mathrm{~m} / \mathrm{m}$.y. Upper Jurassic red and brown limestone and marl accumulated at $9.2 \mathrm{~m} / \mathrm{m} . \mathrm{y}$.

\section{CORRELATION OF SEISMIC REFLECTION PROFILES WITH DRILLING RESULTS}

The correlation is established mainly from the profile recorded by Valdivia several months after the cruise (Figure 11). This profile shows the presence of a first reflector barely visible at about $0.08 \mathrm{sec}$ below the sea floor. This reflector marks the top of a zone of dark reflections near the base of which a second reflector is discernible at about $0.38 \mathrm{sec}$. This second reflector correlates with Horizon A visible in most of the Cape Verde and Canary basins. At about $0.7 \mathrm{sec}$ below the 


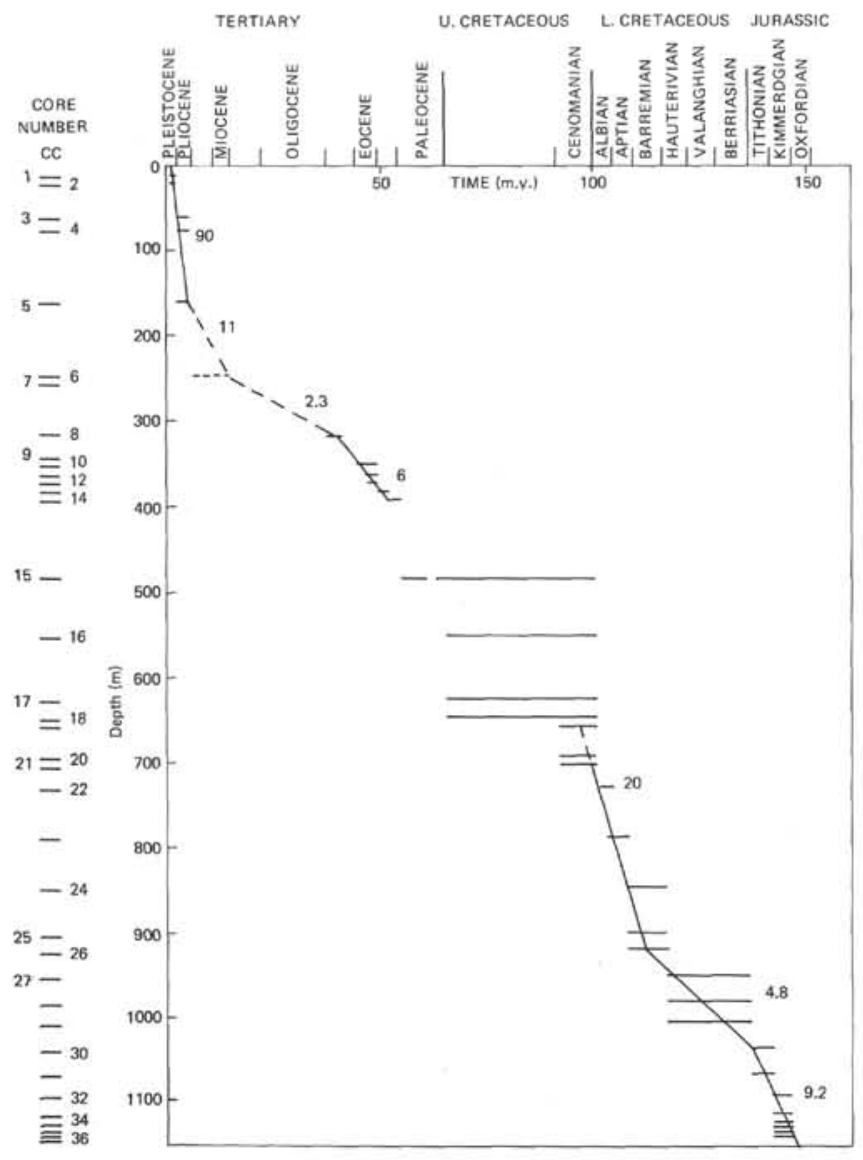

Figure 10. Plot of accumulation rates at Site 367.

sea floor begins a reflecting zone that extends down to about $0.8 \mathrm{sec}$. The lowermost part of the record shows a relatively thick zone of reflectors beginning gradually at about $1.1 \mathrm{sec}$. The upper part of this lowermost reflecting zone appears clearly of sedimentary origin. The lower half, below about $1.18 \mathrm{sec}$ near the site, however, shows a subtle but definite change in character that can be interpreted as basaltic basement.

The first reflector at about $0.08 \mathrm{sec}$ probably correlates with the occurrence of sand layers in Cores 3 and 4 . The correlation cannot be very precise because intermittent coring prevents a good comparison between the facies present above and below that level. We assume that most of the section between about 50 and more than 160 meters consists of interbedded sand and marl responsible for the highly reverberating zone present in the upper part of the profiler record. The reflector at $0.08 \mathrm{sec}$ is barely visible in that zone and might correspond with more massive sand accumulation than above.

The reflector at about $0.38 \mathrm{sec}$ below the sea floor correlates well with the youngest occurrence of chert in the hole at about 320 to 300 meters subbottom, and therefore can be considered as equivalent to Horizon A from the western basins. Such a correlation implies an average sound velocity of about $1.7 \mathrm{~km} / \mathrm{sec}$ for the interval between the sea floor and Horizon A. Such a value appears reasonable for a section supposed to consist mainly of marls. It also agrees quite well with the velocities measured on samples.
The correlation between the lower reflectors and the lithology is more problematic. The reflector at $0.7 \mathrm{sec}$ shows an acceptable correlation with the top of the black shale unit, encountered at about 620 meters, if a velocity of $1.85 \mathrm{~km} / \mathrm{sec}$ is inferred for the overlying silty clay interval. The reflector at $0.8 \mathrm{sec}$ could correspond with hard dolomitic beds within the black shale. A hard layer of dolomite was encountered at about 700 meters and it is possible that several other layers or nodules occur around that level. If we correlate the reflector with hard layers at about 715 meters, then the sound velocity for the interval between the reflectors observed at 0.7 and $0.8 \mathrm{sec}$, respectively, would be $1.9 \mathrm{~km} / \mathrm{sec}$. In any case, this correlation shows that this reflector is not equivalent to Horizon $\beta$ from the western basin but rather corresponds with Horizon $\mathrm{A}^{*}$ correlated with the top of the black shale unit in the North American Basin (Ewing, Hollister, et al., 1972).

No well-defined change in the lithology accounts for the presence of the moderately strong reflector at 1.1 sec below the sea floor. The major change in lithology seems to be the transition between the variegated claystone of Core 24 and the underlying limestone. It is not possible, however, to correlate this change with the reflector at $1.1 \mathrm{sec}$ if reasonable sound velocities are considered. The reflector at $1.1 \mathrm{sec}$ might correlate with a break in the drilling rate observed at about 1005 to 1010 meters. If this interpretation is correct, then the sound velocity for the interval comprising the lower part of the black shale and the upper part of the limestone would be about $1.95 \mathrm{~km} / \mathrm{sec}$. The top of the limestone could be rather transitional, and examination of the seismic profile recorded while approaching the site shows that a moderate reflector which could be considered as the equivalent of Horizon $\beta$ marks that transition. At the drill site this reflector would be masked by the reverberation of the reflector at $0.8 \mathrm{sec}$ (Figure 11).

Below that level we can correlate a barely visible change in the character of the lowermost reflecting zone, at about $1.2 \mathrm{sec}$, with the top of the basalt. This would yield an average velocity of $2.7 \mathrm{~km} / \mathrm{sec}$ for the limestones and argillaceous limestones.

\section{SUMMARY AND CONCLUSIONS}

The most impressive result obtained at Site 367 is the striking similarity between the succession of Mesozoic facies sampled at this site and those described in the western North Atlantic (Hollister, Ewing, et al., 1972; Lancelot et al., 1972). This confirms the symmetrical evolution of both sides of the North Atlantic during the Mesozoic, prior to the major changes caused by wide communication with other oceanic basins and onset of vigorous thermohaline circulation sometime during the early Tertiary. This evolution started with the deposition of deep-water carbonates which became covered by clays when continuous subsidence-caused by the regularly increasing distance from the MidAtlantic Ridge-brought basins below the level of the $\mathrm{CCD}$. The schematic picture simply derived from the sea floor spreading concepts is complicated by the occurrence of black shales above the carbonate sequence. 


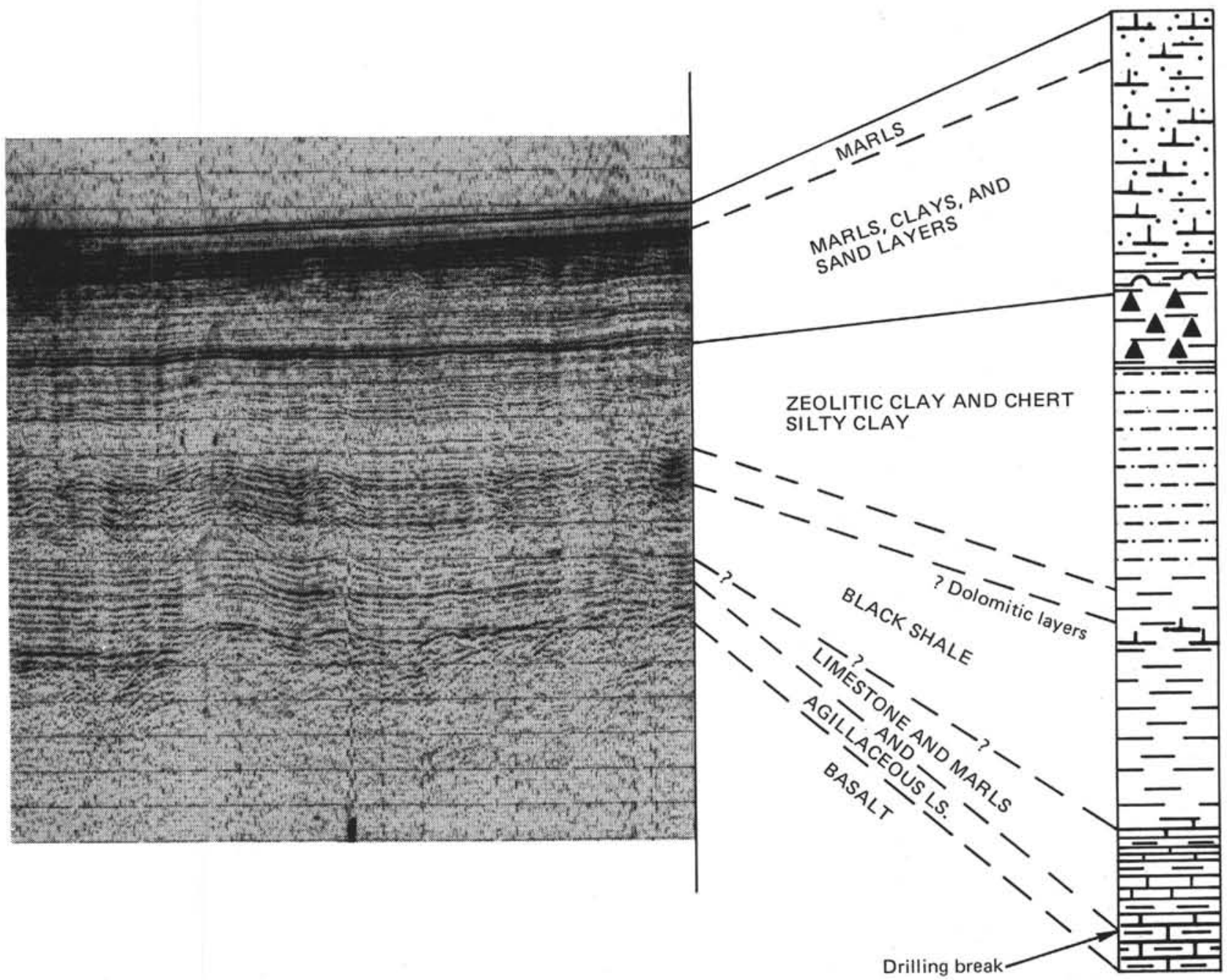

Figure 11. Correlation of drilling results with seismic reflection profile at Site 367. (Valdivia 10-1975 seismic profile).

We shall summarize here the vertical succession of facies and discuss briefly their significance in terms of environmental evolution of the basin. Figure 12 is a graphic summary of the lithology, biostratigraphy, sonic velocity, age, and drilling rates of Site 367 .

\section{Basalt}

The occurrence of basalt in Core 38 at 1146 meters below the sea floor was somewhat of a surprise because the seismic reflection profiles recorded over the site prior to and during the cruise did not show reflection clearly characteristic of the basement. The basalt is fine grained and fractured with numerous calcite-filled veinlets. It is, in places, brecciated and also contains inclusions of completely recrystallized sediment (chert and carbonate). The uppermost centimeters appear relatively glassy. It has all the appearances, both macroscopically and in thin sections, of the basement rocks already cored at many previous DSDP sites and does not show any definite increase in grain size with depth. The contact with the sediment does not show any good evidence of thermal alteration. However, because the rocks are highly recrystallized by diagenesis, it is impossible to exclude completely contact metamorphism.
The age of the basement in this area was expected to be older than middle Oxfordian because the lowermost reflector was interpreted as reflector $\mathrm{C}$ by comparison with the profiles recorded off Morocco on the basis that it appeared to be the lowermost reflector of sedimentary origin visible on the record. This reflector at Site 367 cannot be followed easily westward to its contact with basement, however, because of the orientation of the Vema 29 profile (Figure 2). Unpublished data, made available to us just prior to this cruise, show that Site 367 is not as far from the boundary of the quiet magnetic zone as we had inferred from its distance to the margin, because the quiet zone appears exceptionally narrow off the widely prograding Senegal continental shelf (Figure 1). If we extrapolate the $1 / 2$ spreading rate of about $2.2 \mathrm{~cm} / \mathrm{yr}$ calculated from the Mesozoic magnetic anomalies dated by Larson and Pitman (1972), then the age of the basement at Site 367 could be expected to be approximately three million years older than at Site 105. Paleontological results from the study of the lowermost sediments are not precise enough to distinguish between these ages. Radiometric age determinations performed after the cruise indicated a Cenomanian age for the basalt. Alteration of the rocks, however, was evident and the 


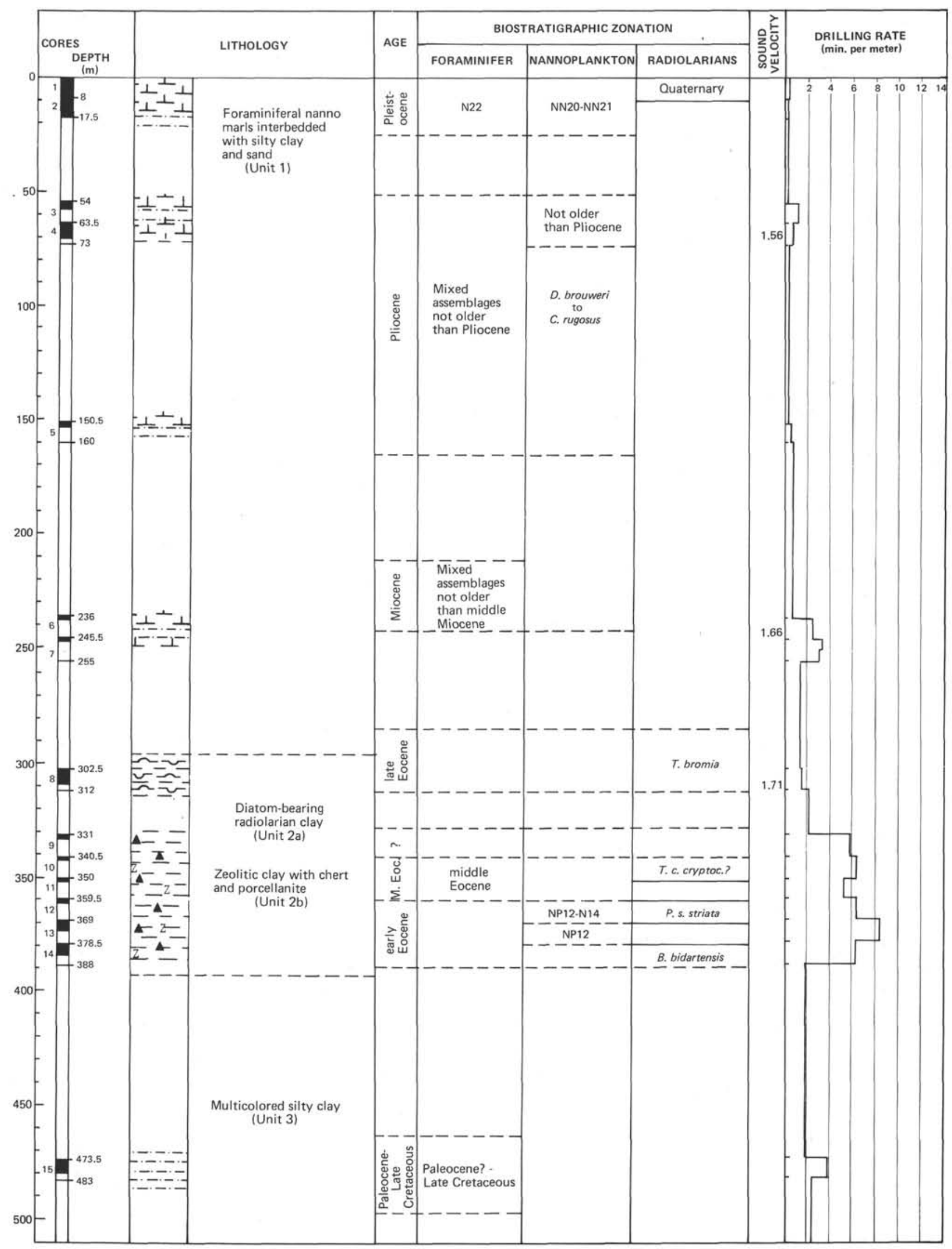

Figure 12. Graphic summary of lithology, age, biostratigraphy, sonic velocity, and drilling rates of Site 367. 


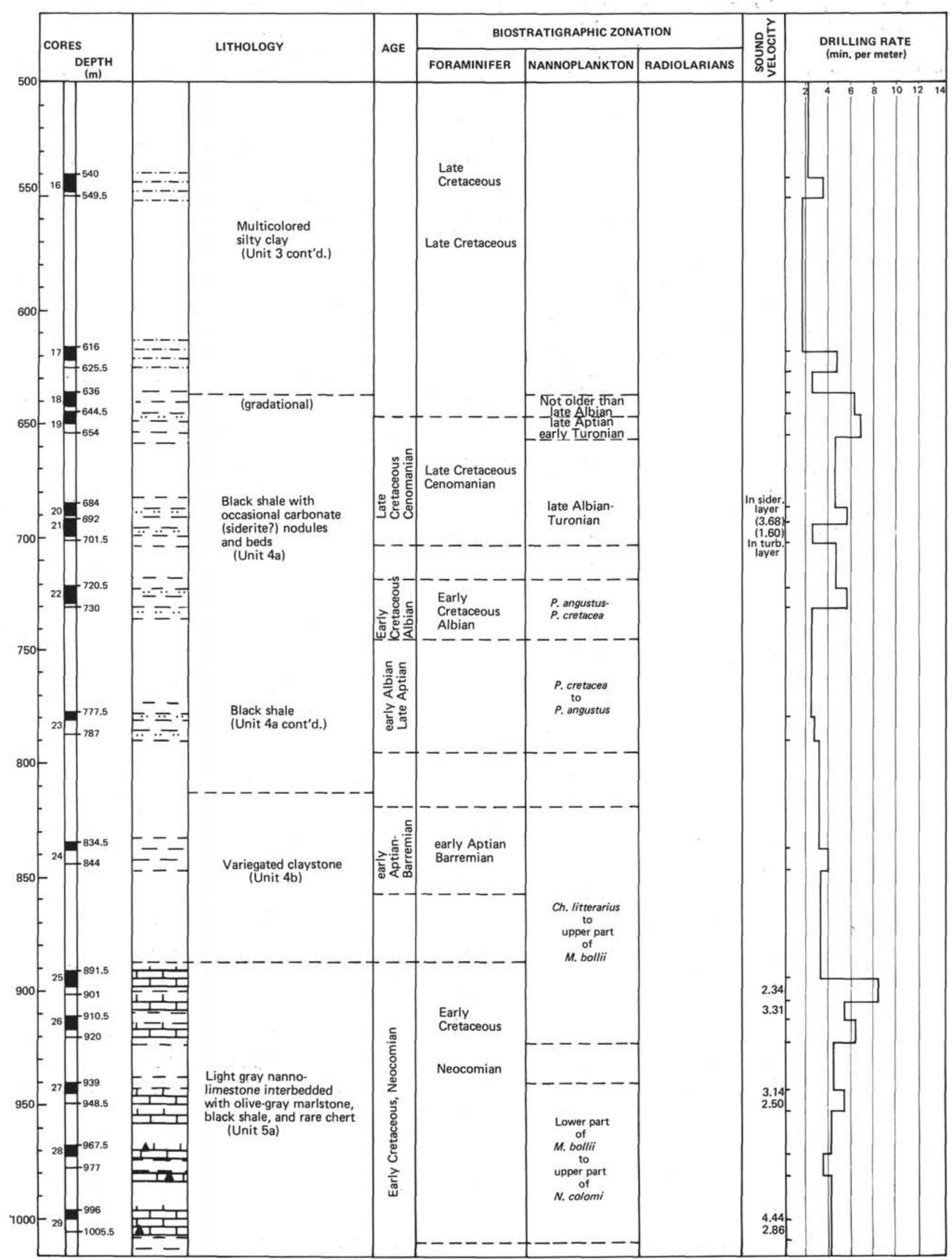

Figure 12. (Continued). 


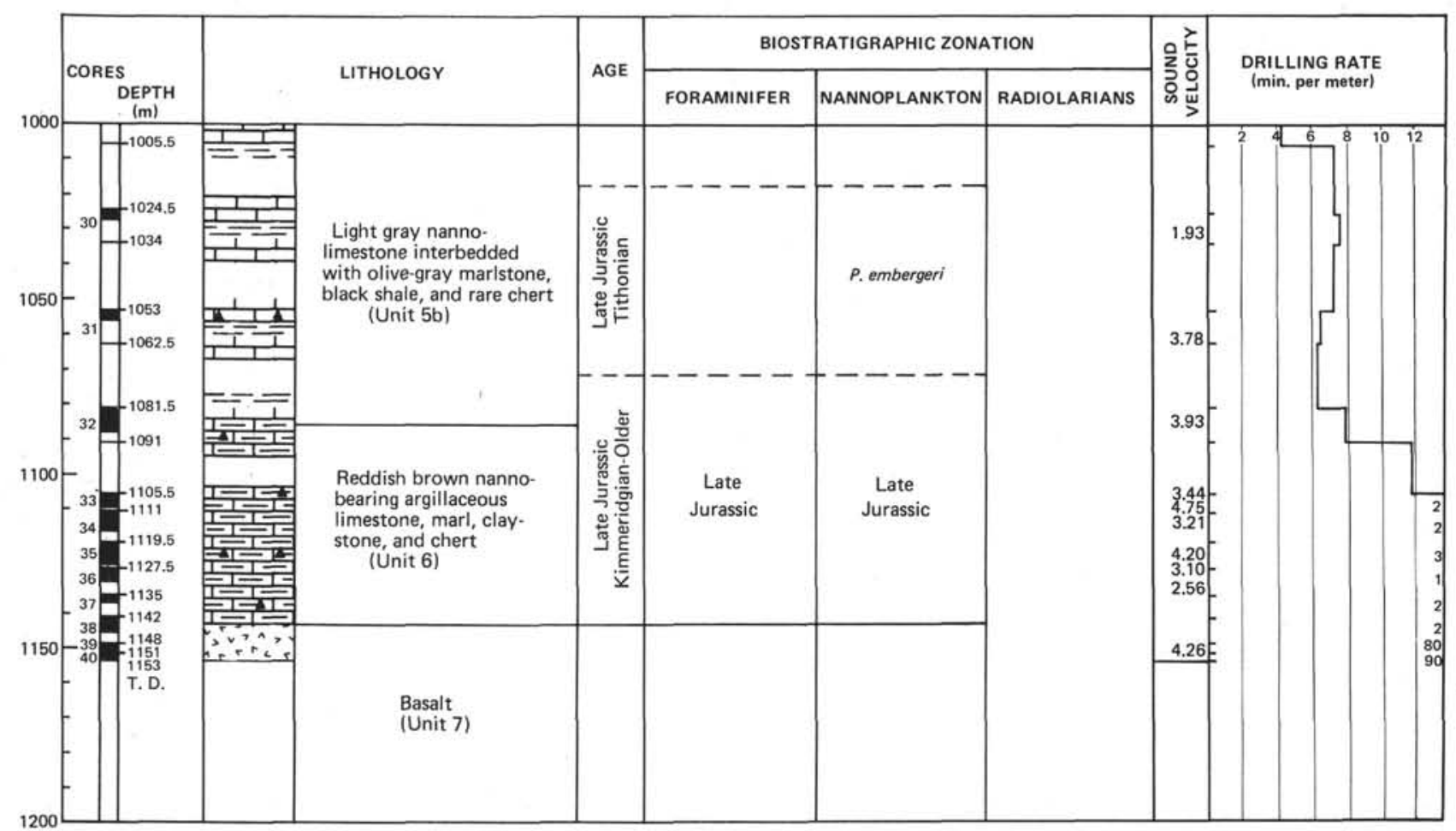

Figure 12. (Continued).

values obtained are not considered very reliable (Duncan and Jackson, this volume).

If the basalt encountered at this site is a sill, then it must have either been intruded sometime in the Late Jurassic, hence it would be almost as old as the regional basement, or younger but intruded near the basementsediment interface. Both petrological and post-cruise seismic profiling strongly support the interpretation of the basalt sampled at this site as representing the top of the oceanic crust (layer 2) that was formed on the ridge crest in Jurassic times.

\section{Jurassic-Neocomian Carbonates}

The basal carbonate sequence consists of two successive units-Oxfordian-Kimmeridgian red argillaceous limestones and alternations of dark gray, finely laminated marls and light gray burrowed limestones of Tithonian-Neocomian age. They represent a pelagic deposit in a basin situated above the CCD. The water depth is considered to increase regularly from bottom to top, but even at the base of the section the sediments indicate deep-water deposition. The fossils found in these layers are predominantly pelagic (planktonic and nektonic) and benthic faunas are rare (benthic foraminifers only). The most striking fossils, besides the classical assemblages of planktonic foraminifers, coccoliths, and radiolarians, are the ammonoidea (numerous aptychi and some ammonites), and, in the reddish brown layers, pelagic lamellibranchiates and pelagic echinoids (Saccocoma). Abundant bioturbation indicates a well-oxygenated environment. These layers are almost identical to layers of the same age sampled during Leg 11 at Sites 99, 101, and especially
Site 105. The similarities can be observed even in minute details of the sedimentary structures (Lancelot et al., 1972). The only differences are both the lesser amount of redeposition structures (turbidites and slumping) and the greater amounts of chert at Site 367. The lack of major redeposition features at this site appears directly related to a much lower relief environment. The relative abundance of chert might result in differences in surface water productivity due to different water circulation patterns over both basins. These sediments are very similar to the "Ammonitico Rosso," "Marne a Fucoide," and Maiolica facies of the Tethys realm from the Dinarides and Alps to the Subbetic and North African geosynclines (see discussion in Jansa et al., this volume; Bernoulli, 1972). This confirms the existence of good communication between the young Atlantic and Tethys in the Late Jurassic and Early Cretaceous. More regionally, the Neocomian part of the section compares extremely well with the sediments of the same age outcropping on Maio Island (Cape Verde islands) and described by Stahlecker (1934).

\section{Barremian-Early Aptian Variegated Claystone}

This facies, recovered in only one core (Core 24), which occurs between interbedded dark and light gray limestone and black clay, was not found in the western North American basin. At Site 105 a gradual transition can be directly observed, through continuous coring, between the limestones and the overlying black clays. The dark marly interbeds in the limestones are gradually thicker and darker toward the upper limit of the limestone facies until the limestone beds disappear 
completely in the black shale facies. Such a transition can be interpreted as the gradual onset of poorly oxygenated conditions in the basin. Here, at Site 367, the occurrence of carbonate-free variegated red and green claystones between the limestones and the black shales mark an interruption in the gradual increase of reducing conditions. This could result from a regional temporary bottom circulation in the eastern basin. The occurrence of relatively well-oxygenated, deep-sea clay at that level is interesting as it provides some indication about the time at which the floor of the basin crossed the level of the CCD. This cannot be observed in the western basin because the black clays are very poor water depth indicators. Such facies are found today in every range of water depth, even on continental shelves or in epicontinental seas whenever the oxygenation on the bottom is relatively poor. The presence of variegated, carbonate-free clays at the base of the black clays would indicate that unless the CCD deepened drastically during the Aptian-Albian times, the latter facies was deposited below the CCD, probably in a relatively deep basin.

\section{Late Aptian-Cenomanian Black Shale}

This facies, similar in age and composition to the one sampled in the North American Basin, shows typical features of reducing environments. Particularly characteristic are the abundances of organic matter (up to $6.7 \%$ of organic carbon), the occurrences of typical authigenic minerals such as dolomite and possibly siderite and abundant pyrite, and the abundance of natural gas (methane). The significance of reducing environments in deep-sea basins is not entirely clear. The reducing conditions can occur either at or above the water-sediment interface or within the sediments. In the first case, the simplest explanation is a more or less stagnant environment in the basin or a well layered circulation which does not bring oxygenated waters to the bottom (Black Sea type). In the second case, if the bottom waters are oxygenated, then one must invoke a very steady and high input of organic matter in the sediment to avoid oxidation at, or very close to, the sea bottom (see Gardner et al., this volume). Of course an intermediate case is also possible. In the case of the black shales of both the western and eastern North Atlantic basins several indications point toward at least a reduced bottom circulation, although the occurrence of occasional burrows in the sediments shows that the environment was probably not completely anoxic, hence not completely stagnant. The rate of accumulation does not exceed $20 \mathrm{~mm} / 1000 \mathrm{yr}$ (not corrected for compaction) and such a value does not seem high enough to explain reducing conditions maintained within the sediments if the overlying waters are well oxygenated. For example, on the Blake-Bahamas outer ridge, reducing conditions are maintained within the sediments, although the bottom is permanently swept by currents, but there the rates of accumulation reach values as high as $190 \mathrm{~mm} / 1000 \mathrm{yr}$ (Ewing and Hollister, 1972). Furthermore, the very wide distribution of reducing environments in the deep North and South Atlantic basins, covering a wide range of latitudes, during the Early Cretaceous and to a lesser extent during the Late Cretaceous, suggests that the possible restriction of bottom circulation during these times might be a more determinant factor than excessive input of organic matter in the basins. Geochemical studies found elsewhere in this volume examine in greater detail the origin of the organic matter.

\section{Late Cretaceous-Early Tertiary (?Paleocene) Multicolored Silty Clay}

These sediments are mainly of terrigenous origin and deposited below the CCD. Their silt content is relatively low and they reflect mainly a distal terrigenous facies. Comparison with the thick terrigenous accumulation found under the continental shelf and in the Senegal Basin suggests that only a small fraction of the terrigenous output reached the basin and that most of it was trapped in the subsiding continental shelf areas. The same observation can be made on the western side of the Atlantic where Cretaceous terrigenous deposits make up a very large part of the thick layers underlying the continental shelf off Cape Hatteras whereas the Upper Cretaceous sediments in the North American Basin appear extremely reduced or even maybe entirely missing.

Although these sediments at Site 367 are described as multicolored, they do not reflect the same metalenriched zeolitic environments as at Site 105. This difference might be interpreted as resulting from lesser volcanic activity in the eastern basin during the Late Cretaceous. It might also indicate that the barren, multicolored, highly zeolitic clay of Site 105 could be of early Tertiary age and could correlate with the early and middle Eocene zeolitic clays of Site 367. Strong bottom current circulation would have either greatly reduced deposition of Late Cretaceous sediments or eroded most of them in the North Atlantic Basin.

The presence in these layers of assemblages of agglutinated foraminifers bearing a very strong resemblance with those found in the Alpine flysch of the same age is interesting.

\section{Eocene Siliceous and Zeolitic Clays}

The Eocene is characterized by a worldwide high content in silica. This silica is either in the form of radiolarian tests or recrystallized in chert nodules and porcellanitic beds. Both lithologies are found here associated with zeolitic clays and it is tempting to relate the increased input of silica in the ocean with a phase of volcanic activity. However, comparison with the western North Atlantic where no chert or radiolarians were found associated within the highly zeolitic sediments shows that other factors might be equally important in the sudden "radiolarian bloom" commonly observed in the world ocean during the early Tertiary. The absence of chert at Site 105 might also be caused by sampling gaps.

The Eocene sediments show alternations of black and green clay in which the organic carbon content varies from $2.5 \%$ to $0.3 \%$, respectively. This cyclic (decimeter-scale) sedimentation might reflect variations in the input of terrigenous sediments or cyclic variations in the bottom current circulation (see Dean et al., this volume). 


\section{Post-Eocene Nannofossil Marl and Silty Clay}

This section has been only partially sampled and the stratigraphic control toward the base of the interval is not well established. It appears, however, that the unsampled pre-middle Miocene section is greatly reduced in thickness. This might reflect the presence of hiatuses or at least very condensed sections in the lower Miocene and Oligocene sediments.

The two main characteristics of these sediments are the increase in terrigenous, often coarse-grained, material and the relative abundance of calcareous microfossils. The terrigenous input increases regularly upward in the section, and the Pliocene and Quaternary sediments, with accumulation rates up to $90 \mathrm{~m} / \mathrm{m}$.y., contain sand and silt beds deposited by turbidity currents. Other evidences of redeposition of material of shallow-water origin are also provided by the occurrence of reworked microfossils of Mesozoic and Cenozoic age in these layers. Such evidences of downslope transportation are in good agreement with the physiographic situation of Site 367 (see Figure 1). The lower continental rise off southern Senegal and Guinea is crossed by several channels that probably have played a major role in building the lower continental rise since at least the Pliocene and possibly since the upper Miocene, by collecting and spreading the terrigenous material brought downslope through the numerous incisions visible on the adjacent continental slope.

\section{Sedimentological Problems}

\section{Cyclic Sedimentation $=$ Dilution Versus Dissolution; Role of Diagenesis}

Cyclic sedimentation was encountered at this site. A more detailed report on this problem is found in Dean et al., this volume. In general the cycles correspond to alternations of terrigenous-rich/biogenous-poor and terrigenous-poor/biogenous-rich beds. It is difficult to determine which part of the cyclicity is due to variation in the input of terrigenous material and which part is due to dissolution of the calcareous material. Furthermore, it is difficult to assess, in the case of dissolution, if the dissolution occurred at or very near the sea floor or if it occurred after burial and was caused by diagenesis. Other cycles, such as the color banding observed in the Eocene green and black clays or in the variegated red and green Barremian claystones, might result from diagenetic changes of the redox potential within the sediments. Such changes might be influenced by the primary composition of the sediments which, in turn, might result from environmental conditions such as input or bottom water circulation. There are some cases, however, where it appears possible to make a distinction between dilution and dissolution cycles. Dilution cycles, for example, are suspected when the terrigenous-rich layers contain relatively abundant, well-preserved microfossils dispersed in clay layers, whereas in dissolution cycles either the clays are barren or they contain rare and very poorly preserved faunas. The cycles observed in the Neocomian-Tithonian dark gray-light gray limestones, for example, appear to be dilution cycles.

\section{Diagenesis and Lithification}

This hole offers a good opportunity to study diagenetical lithification of both carbonate and noncarbonate rocks under relatively high overburden loads.

The carbonate rocks display the classical stages of lithification observed at several previous DSDP sites: overgrowth on coccoliths begins at about 300 meters subbottom. At about 900 meters actual cementation (micritization) occurs and the first real limestones appear. In these limestones the degree of cementation is affected directly by the clay content of the sediments, as can be observed easily near the base of the sedimentary section where dark marl is always softer than white limestone. The same observation was made at Site 105 (Lancelot et al., 1972), but here at Site 367, because of a thicker overburden, the phenomenon is even more striking and the light gray, almost pure limestone is very hard and almost completely recrystallized. The first styloliths appear in limestone at about 1050 meters. This had been rarely observed in Deep Sea Drilling samples until now.

The clays simply lose their water under high pressure caused by overburden. They remain plastic until about 650 meters subbottom, then they gradually become fissile and shaly. Even below 1150 meters they still retain some plasticity.

\section{REFERENCES}

Barnard, T. and Hay, W.W., 1974. On Jurassic coccoliths: a tentative zonation of the Jurassic of southern England and north France: Eclog. Geol. Helv., v. 67, p. 563-585.

Berger, W.H. and von Rad, U., 1972. Cretaceous and Cenozoic sediments from the Atlantic Ocean. In Hayes, D.E., Pimm, A.C., et al., Initial Reports of the Deep Sea Drilling Project, Volume 14: Washington (U.S. Government Printing Office), p. 787-954.

Bernoulli, D., 1972. North Atlantic and Mediterranean Mesozoic facies: a comparison. In Hollister, C.D., Ewing, J.I., et al., Initial Reports of the Deep Sea Drilling Project, Volume 11: Washington (U.S. Government Printing Office), p. 801-871.

Bukry, D. and Bramlette, M.N., 1969. Coccolith age determinations-Leg 1, DSDP. In Ewing, M., Worzel, J.L., et al., Initial Reports of the Deep Sea Drilling Project, Volume 1: Washington (U.S. Government Printing Office), p. 369-387.

Burckhardt, C., 1906. La faune jurassique de Mazapil: Bol. Inst. Geol. Mexico, v. 23.

1912. Faunes jurassiques et cretaciques de San Pedro del Gallo: Bol. Inst. Geol. Mexico, v. 29. 1919. Faunes jurassiques de Symon: Bol. Inst. Geol. Mexico, v. 33

Ewing, J.I. and Hollister, C.D., 1972. Regional aspects of deep sea drilling in the western North Atlantic. In Hollister, C.D., Ewing, J.I., et al., Initial Reports of the Deep Sea Drilling Project, Volume 11: Washington (U.S. Government Printing Office), p. 951-973.

Hayes, D.E., Pimm, A.C., et al., 1972. Initial Reports of the Deep Sea Drilling Project, Volume 14: Washington (U.S. Government Printing Office).

Hayes, D.E. and Rabinowitz, P.D., 1975. Mesozoic magnetic lineations and the magnetic quiet zone off northwest Africa: Earth Planet. Sci. Lett., v. 28, p. 105-115.

Hollister, C.D., Ewing, J.I., et al., 1972. Initial Reports of the Deep Sea Drilling Project, Volume 11: Washington (U.S. Government Printing Office), p. 1077. 
Jacobi, R. and Hayes, D.E., in preparation. Bathymetry and microphysiography of the continental margin off northwest Africa.

Lancelot, Y., Hathaway, J.C., and Hollister, C.D., 1972. Lithology of sediments from the western North Atlantic-Leg 11, Deep Sea Drilling Project. In Hollister, C.D., Ewing, J.I., et al., Initial Reports of the Deep Sea Drilling Project, Volume 11: Washington (U.S. Government Printing Office), p. 901-949.

Larson, R.L. and Pitman, W.C., III, 1972. World-wide correlation of Mesozoic magnetic anomalies, and its implications: Geol. Soc. Am. Bull., v. 83, p. 3645-3662.

Luterbacher, H., 1972. Paleocene and Eocene planktonic foraminifera, Leg XI, Deep Sea Drilling Project. In Hollister, C.D., Ewing, J.I., et al., Initial Reports of the Deep Sea Drilling Project, Volume 11: Washington (U.S. Government Printing Office), p. 547-550.

Stahlecker, R., 1934. Neocom auf der Kapverden-Insel Maio: Neuen Jb. Mineral., Beil.-Bd. 73, Abt. B, p. 265-301. 1935. Neocom auf der Kapverden-Insel Maio: N. Jb. Min. Geol. Pal., v. 73 , p. 265-301.

Thierstein, H.R., 1971. Tentative Lower Cretaceous calcareous nannoplankton zonation: Eclog. Geol. Helv., v. 64 , p. $459-488$.

van Hinte, J.E., 1972. The Cretaceous time scale and planktonic foraminiferal zones: Koninkl. Nederl. Akad. Vanwetenschappen, v. 75 , p. 8.

1976. A Jurassic time scale: Am. Assoc. Petrol. Geol. Bull., v. 60 , p. $489-497$.

von Rad, U. and Rosch, H., 1972. Mineralogy and origin of clay minerals, silica, and authigenic silicates in Leg 14 sediments. In Hayes, D.E., Pimm, A.C., et al., Initial Reports of the Deep Sea Drilling Project, Volume 14: Washington (U.S. Government Printing Office), p. 727 751.

Wilcoxon, J.A., 1972. Upper Jurassic-Lower Cretaceous calcareous nannoplankton from the western North Atlantic Basin. In Hollister, C.D., Ewing, J.I., et al., Initial Reports of the Deep Sea Drilling Project, Volume 11: Washington (U.S. Government Printing Office), p. 427457.

\section{APPENDIX A: GEOLOGICAL PROBLEMS OF THE UPPERMOST 8 METERS AT DSDP SITE 367}

L. Diester-Haass, F.C. Kögler, and E. Seibold, Geologisch-Paläontologisches Institut der Universität Kiel, Olshausenstr. 40/60, 23 Kiel, Federal Republic of Germany

\section{INTRODUCTION}

As in most of the DSDP holes, the first core at Site 367 penetrated Holocene and Pleistocene foraminifer-bearing nannofossil marl with severe drilling disturbances and some voids. Therefore, we decided to take some cores during a post-Leg 41 survey at this location with Valdivia in July 1975. We selected a box core of practically undisturbed material (cross-section $30 \times 30 \mathrm{~cm}$, length $8.10 \mathrm{~m}$ ) taken $20^{\circ} 02.74^{\prime} \mathrm{W}$ (Valdivia-10-13209-2) to investigate the uppermost 8 meters of the sediment column. Some physical properties were determined (roughly every $50 \mathrm{~cm}$ ) onboard immediately after the core was taken (Figure Al). Additional physical properties were completed in our shore laboratories. Quantitative coarse-grain analyses were made at $10 \mathrm{~cm}$ intervals. The shipboard core description shows the core is highly bioturbated with no indications of turbidites. Grain-size analysis (Figure Al, n) shows the core consists of clay ( $20 \%$ to $40 \%$ ), silt ( $50 \%$ to $80 \%$ ), and sometimes sand (15\% to $20 \%)$.

The stratigraphic zonation (Figure A la) is based on the presence of abundant Globorotalia menardii (Ericson and Wollin, 1968) and G. tumida and on $\mathrm{CaCO}_{3}$ content (Figure All). The $\mathrm{CaCO}_{3}$ curves from about the same region (Gardner, 1975) show exactly the same trend as that of core 13209. The cores investigated by Gardner (1975) also have biostratigraphical control, therefore, it is possible to correlate the carbonate minima units in core $13209-2$ to glacial periods ( $\mathrm{Y}$ and $\mathrm{W}$ zones) and the carbonate highs to interglacial periods ( $\mathrm{Z}$ and $\mathrm{X}$ zones). Some of the peaks in Figure Al ("physical properties," c-i) do not correspond to peaks and boundaries in Figure A1 (a, 1-u) because physical properties were determined in 13-cm slices. Only the upper boundaries of these slices are indicated in Figure A1.

\section{COMPARISON WITH NEARBY CORES}

Echo-sounder profiles from the area and sketch maps of the bathymetry of Cape Verde region indicate channels probably related to turbidity current activities. Lithologic Unit 1 of the sequence cored at Site 367 contains many turbidites. Therefore, at $12^{\circ} 29.28^{\prime} \mathrm{N}$, $20^{\circ} 04.21^{\prime} \mathrm{W}$, we took other cores in $4743-4753$ meters (corrected) water depth (Station Valdivia 10-13208) and their examination revealed turbidites with coarse-grained quartz sands in the uppermost parts below about $40 \mathrm{~cm}$ depth. This contrasts with the predominately clayey silt facies found in core $\mathrm{Va} 10-13209-2$. The parameters described by Rupke et al. (1974) for fine-tail turbidites could not be found in core Va 13209-2, which may be due partly to strong carbonate dissolution and partly to the methods we have used.

\section{PHYSICAL PROPERTIES AND SEDIMENTATION}

Values of shear strength ( 10 to $20 \mathrm{~g} / \mathrm{cm}^{2}$ ) of the remolded material are low (see Richards, 1961, 1962). The maximum $\left(29.1 \mathrm{~g} / \mathrm{cm}^{2}\right)$ corresponds with the carbonate-rich foraminifer ooze at 263 to 276 $\mathrm{cm}$ core depth (Figure Al, c). Bulk densities of 1.13 to $1.42 \mathrm{~g} / \mathrm{cm}^{3}$ (Figure Al, f) yield overburden pressures of only about $200 \mathrm{~g} / \mathrm{cm}^{2}$ at 8 meters of depth. Bulk and dry density variations (2.50 to 2.65 $\mathrm{g} / \mathrm{cm}^{3}$ ) correlate with carbonate contents. Variations in natural water content (Figure Al, i) are dependent on many factors. It shows roughly a negative correlation with carbonate contents so we assume that most of the Globigerina tests are filled with sediment and not with interstitial water (see Einsele and Werner, 1968). Different composition and degree of bioturbation may have some influence. In general, water content is somewhat higher in the finer grained sections (Figure Al, a: Y, W zones). Relatively high colloidal activities (Figure A1, g, 0.99 to 2.60) indicate active clay fractions in most of the samples (Skempton, 1953), with montmorillonite an important clay mineral. The ratios of shear strength to overburden pressure decrease more or less continuously. Therefore, a normal consolidation without accentuated hiatuses is probable (Figure A1, h).

TABLE A 1

Shipboard Core Description Va 10-13209-2

0-5 Surface layer, technical disturbances

5-18 Foraminifer ooze, brownish, bioturbated, burrows mostly horizontal, diameters up to $1.5 \mathrm{~cm}$, sometimes open

18-30 Clayey silt

30-46 Clayey silt, brownish gray, bioturbated

46-54 Clayey silt, brownish, bioturbated, burrows elliptical, up to $4 \times 1.5 \mathrm{~cm}$, filling is dark gray

54-150 Clayey silt, dark gray, bioturbated, burrows mostly horizontal, diameters up to $5 \mathrm{~cm}$, fecal pellets abundant

150-192 Clayey silt, dark gray, few burrows and fecal pellets

192-291 Foraminifer ooze, light gray, bioturbated

291-295 Foraminifer oooze, light gray

303-380 Clayey silt, dark gray-brown, with bottle-like dark gray features

380-383 Greenish layer

383-505 Clayey silt, dark gray-dark brown, partly lighter colored layers, with bottle-like dark gray features

505-788 Clayey silt-foraminifer ooze, light gray with dark gray parts

Greenish layers at $88-90,279,295,303,310,322,329$, $380-383,688 \mathrm{~cm}$ 
CORE 13209-2

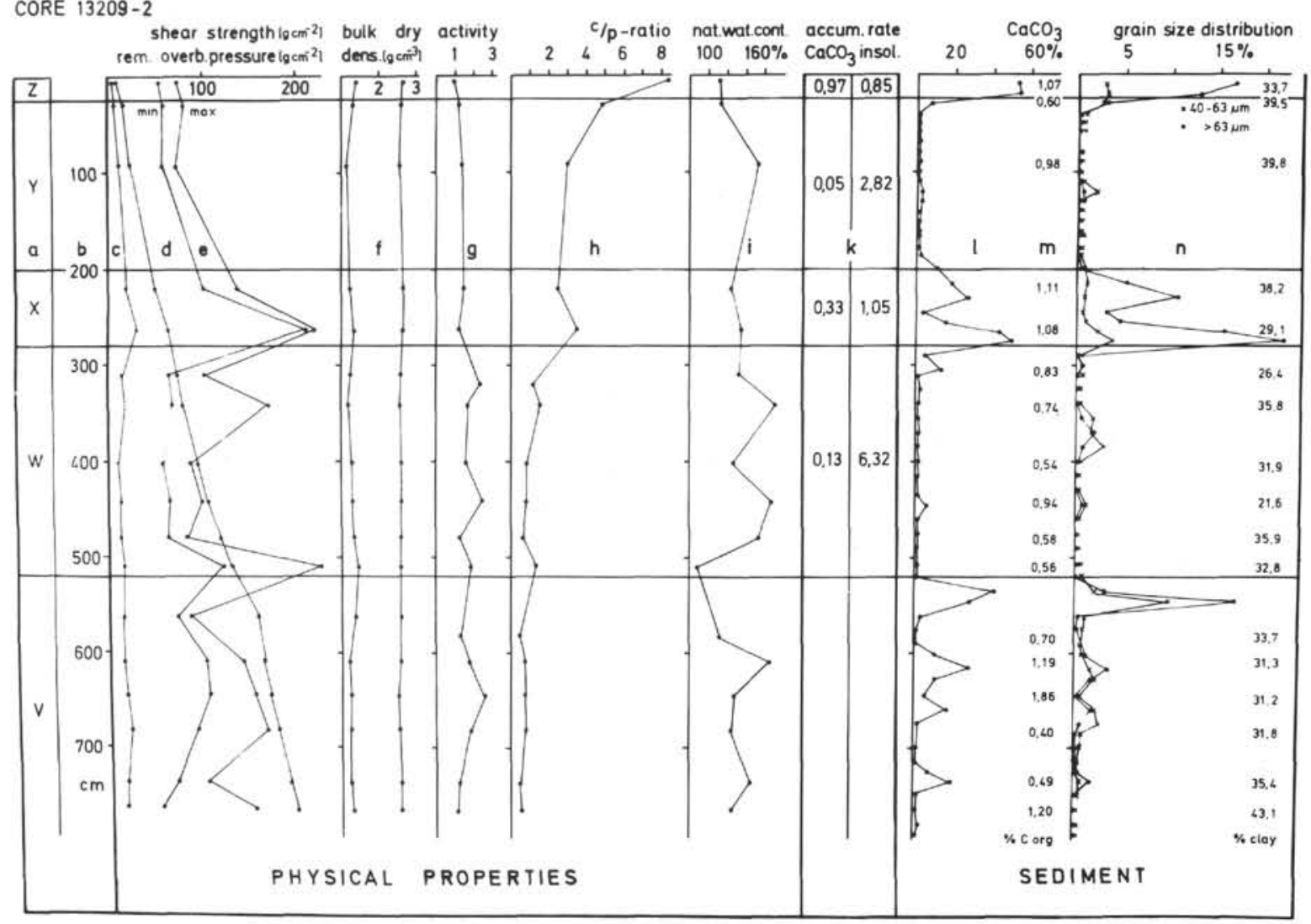

CORE $13209-2$

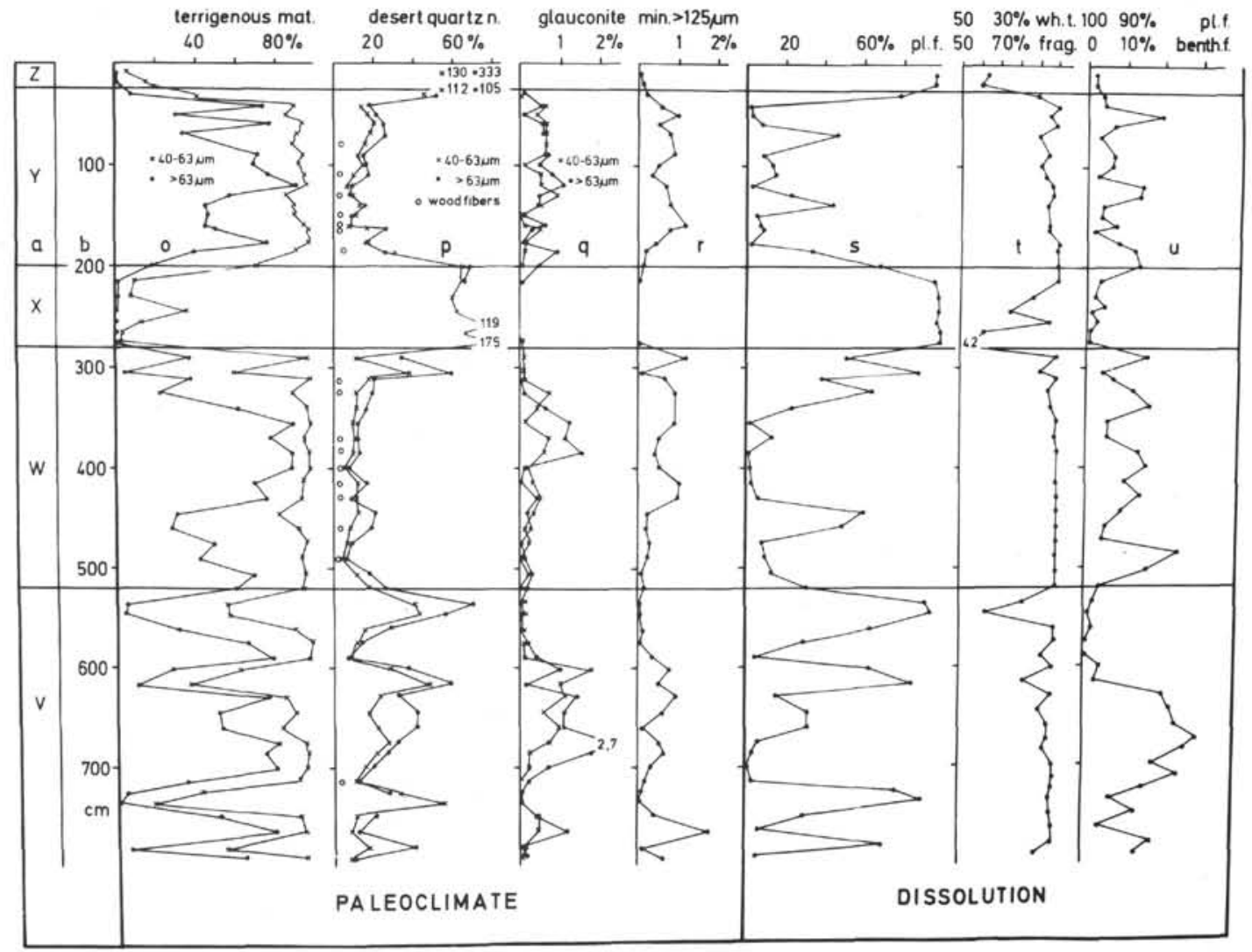

Figure A1. Analytical results from Core Va 13209-2 (Valdvia cruise 10-1975) from Site 367 (a) foraminiferal zones, based on the presence of Globorotalia menardii (tumida) and on amounts of $\mathrm{CaCO}_{3}$ (for explanation see text); (b) depth below surface in $\mathrm{cm} ;(c)$ shear strength (in the remolded state) in $9 / \mathrm{cm}^{2}$; (d) overburden pressure $\mathrm{g} / \mathrm{cm}^{2} ;(e)$ shear 
strength in the natural state in $\mathrm{g} / \mathrm{cm}^{2}$ (min. and max. values from 3 to 8 determinations on $13 \times 13 \mathrm{~cm}$ surfaces from the central part of the $30 \times 30 \mathrm{~cm}$ cross-section; ( $f$ ) bulk and dry density (dens.) in $\mathrm{g} / \mathrm{cm}^{3} ;(\mathrm{g}$ ) activity; (h) C/p ratios (average of natural shear strength divided by overburden pressure; (i) Natural water content (nat. wat. cont.) in \% water of dry weight; (k) accumulation rates of calcium carbonate and total insoluble material (insol.) in $\mathrm{cm} / 10^{3} y r$. Absolute ages for calculation of these rates are taken from Sancetta et al., 1973; (l) Weight percent $\mathrm{CaCO}_{3}$ of total sediment; ( $\mathrm{m}$ ) weight percent organic carbon ( $C_{\text {and }}$ of total sediment: $(n)$ grain size distribution: \% sand (>63 $\mu \mathrm{m}$ ) and \% 40 to $63 \mu \mathrm{m}$ fraction. Right side: \% clay, percents of total sediment; (o) amount of terrigenous material in \% of 40 to $63 \mu \mathrm{m}$ and in $\%$ of $>63 \mu \mathrm{m}$ fractions; $(p)$ desert quartz numbers (ratio of red-stained quartz to colorless quartz) $\times 100$. Open circles indicate presence of wood fibers; (q) amount of glauconite in \% of 40 to $63 \mu \mathrm{m}$ and in $\%$ of $>63 \mu \mathrm{m}$ fractions; ( $r$ ) amount of minerals (min.) >125 $\mathrm{um}$ in \% of the sand fraction; (s) amount of planktonic foraminifers (pl.f.) in the sand fraction; ( $t$ ) fragmentation of planktonic foraminifers calculated as (ratio of fragments to whole tests + fragments) $\times$ 100. wh.t. $=$ whole tests, frag. $=$ fragments; $(u)$ ratio of benthic to planktonic foraminifers calculated as (benthic foraminifers $/$ benthic + planktonic foraminifers $) \times 100$. Benth.f. $=$ benthic, pl.f. $=$ planktonic foraminifers.

Natural shear strengths (Figure Al, a) generally increase with depth, together with overburden pressure. The differences between minimal and maximal values are due to zones with different degree and types of bioturbation and infilling of burrows. The slope of the shear-strength curves may be divided into three parts: 0 to $300 \mathrm{~cm}$ and 300 to $530 \mathrm{~cm}$ show steep slopes which decrease towards the base. Below 530 meters there seems to be no trend. The maximal values at the bases correspond with different materials; mainly higher carbonate, sand, and foraminifer contents. Nevertheless, there also seems to be a general relationship between sediment thickness and natural shear strength (Figure A2). Shear strength increases slower with depth in regions with high accumulation rates than in regions with lower accumulation rates. Data from core $\mathrm{Va}$ 13209-2 are compared with a core from the deeper Gulf of Oman containing turbidites and other cores from regions with higher accumulation rates (Figure $\mathrm{A} 2$ ).

The different slopes in Figure A1, e, may also be related to the different accumulation rates (Figure Al, k). The rate of accumulation in the $\mathrm{Y}$ zone is $2.87 \mathrm{~cm} / 10^{3} \mathrm{yr}$ and that for the $\mathrm{W}$ zone is 6.45 $\mathrm{cm} / 10^{3} \mathrm{yr}$.

\section{CLIMATE AND DISSOLUTION}

The amount of terrigenous material in the $>40 \mu \mathrm{m}$ fraction (Figure $\mathrm{Al}, \mathrm{o}$ ), the amount of desert quartz (Figure Al, p), the presence of wood fibers (Figure Al, p) which were probably transported by rivers, and the amount of minerals in the $>125 \mu \mathrm{m}$ fraction (Figure Al, r) can be interpreted in terms of paleoclimate (for details see Diester-Haass, this volume).

The amount of terrigenous material in the coarse fractions in the interglacial $Z$ and $X$ zones is low, desert quartz numbers are high, no wood fibers and almost no minerals $>125 \mu \mathrm{m}$ in size are present. These sediments reflect the influence of a desert environment with low supply of fluviatile material.

The opposite is found during the glacial periods $\mathrm{W}$ and $\mathrm{Y}$ zones. Very high amounts of terrigenous material in the $>40 \mu \mathrm{m}$ fraction are seen (up to $>90 \%$ in the $40-63 \mu \mathrm{m}$ fraction), desert quartz numbers are very small $(<20)$, and wood fibers occur as well as minerals $>125$ $\mu \mathrm{m}$ in size. This all suggests a reduced influence from deserts. Addition of fluviatile material at these times is probable as shown by the presence of wood fibers (Sarnthein, 1971) and by the coarse minerals. The maximum size of quartz being transported in suspension by wind is about $80 \mu \mathrm{m}$ (Bagnold, 1954) so the minerals $>125 \mu \mathrm{m}$ is size have been transported by an agent with higher transport capacity.

The alternation of sediment reflecting desert influence in interglacial periods and units reflecting fluviatile input during glacial periods is explained in the following way. When sea level was high, the river-borne material transported by the Gambia River did not reach Site 367 because most of the material was captured on the shelf. Only the influence of the northeast trade winds blowing from the Sahara is obvious at the site, a region situated in the zone of most frequent dust fall occurrence (Folger, 1970).

During the glacial $\mathrm{W}$ and $\mathrm{Y}$ zones, sea level was at least 100 meters lower than during interglacial periods and fluviatile material was transported by rivers to the shelf-break region where it could be reworked and transported in suspension by turbidity currents to the area of Site 367. Accumulation rates of terrigenous components $>63$ $\mu \mathrm{m}$ in size increase from $0.0012 \mathrm{~cm} / 10^{3} \mathrm{yr}-\mathrm{Z}$ Zone $\left(0.0003 \mathrm{~cm} / 10^{3}\right.$ $\mathrm{yr}-\mathrm{X}$ Zone) to $0.0033 \mathrm{~cm} / 10^{3} \mathrm{yr}-\mathrm{Y}$ Zone $\left(0.012 \mathrm{~cm} / 10^{3} \mathrm{yr}-\mathrm{W}\right.$ Zone). Consequently, the high amounts of terrigenous material in the glacial sections are not simply the result of increased dissolution during glacial periods.
The presence of glauconite (Figure Al, q) and phosphorite grains in the glacial sections indicates shallow water conditions (lowered sea-level) (Diester-Haass, this volume). The low or disappearing desert influence during glacial periods is surprising because the arid zone with red dunes shifted as far south as about $14^{\circ} \mathrm{N}$ (Michel, 1973). The more easterly component of the glacial trade winds (Sarnthein and Walger, 1974; Diester-Haass, 1976) is probably responsible for the reduced or disappearing desert influence in the area of Site 367.

The degree of carbonate dissolution can be derived from the amount of planktonic foraminifers in the coarse fractions (Figure A1, $\mathrm{s})$, the fragmentation of planktonic foraminifers (Figure A1, t) (for details see Diester-Haass, this volume), and the ratio of planktonic to benthic foraminifers (Figure $\mathrm{Al}, \mathrm{u}$ ). Carbonate dissolution was minimal during interglacial periods, as shown by planktonic foraminifer percentages in the sand fraction up to $99 \%$, fragmentation values of $42 \%$ to $80 \%$, and low ratios of benthic to planktonic foraminifers. Glacial periods witnessed a strong increase in dissolution which decreased planktonic foraminifers to less than $20 \%$ and sometimes completely eliminated them from the sediment. Fragmentation increased up to $100 \%$ and the ratio of benthic to planktonic foraminifers increased. The strong dissolution caused the low sand fraction values of total sediment in glacial periods and conversely weak dissolution allowed higher amounts of sand-sized carbonate material (Figure Al, n).

Gardner (1975) explained the intense dissolution in glacial periods by a rise of the lysocline from about $4500-4750$ meters today to 4327 . 3750 meters in glacial periods due either to an increased influence of northward flowing Antarctic bottom water or to the generation of a southward flowing North Atlantic deep water.

The repeated change from glacial to interglacial conditions can produce a cyclic sedimentation of marl (or chalk) and clay as shown

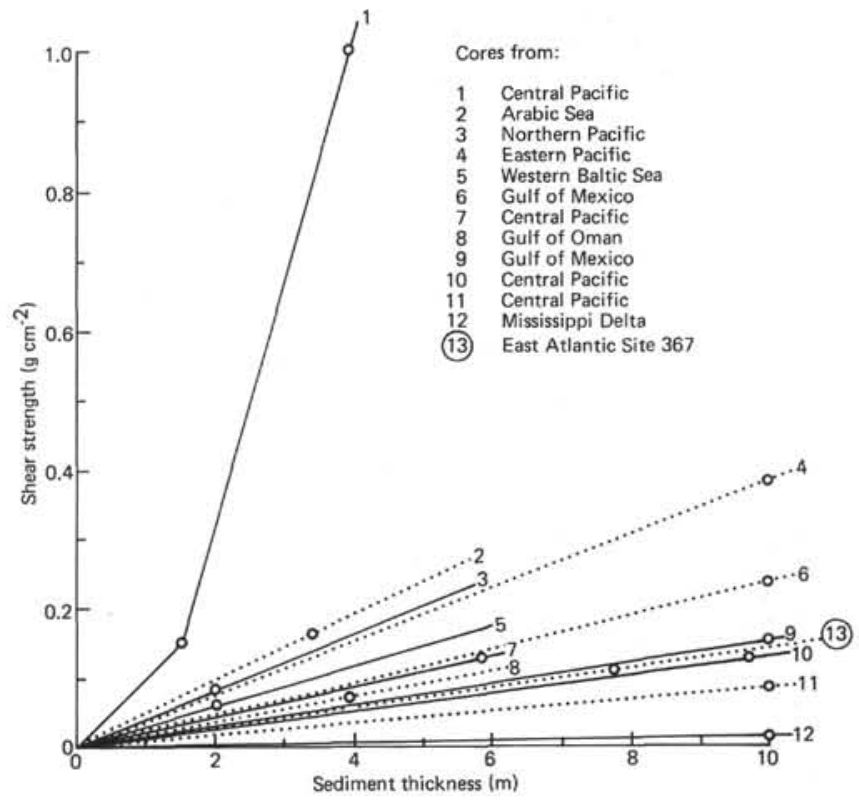

Figure A2. General relations between overburden pressure and shear strength (Kögler, 1974). 
by the contents of calcium carbonate (Figure A1, l) by: (a) fluctuations in dissolution; (b) an increase in dilution by terrigenous input (Dean et al., this volume). The accumulation rates of total insoluble terrigenous material increase by a factor of 3 (and 6, taking into account the increased turbidity current influence in the W Zone, Figure A1, k) in glacial periods compared to interglacial ones.

Organic matter content (Figure Al, m) does not seem to be directly related to contents of clay (Figure $\mathrm{Al}, \mathrm{n}$ ) or wood fibers (Figure Al, p) or dissolution effects, but does seem to correlate with dilution by terrigenous material. Fluctuations in productivity cannot be assessed with our data.

\section{ACKNOWLEDGMENTS}

We thank Master Papenhagen and the crew of Valdivia, Dr. Ackermand (phosphorite determinations), Dr. Muller (calcium carbonate determinations), J. German and N. Mühlhan (physical properties determination), B. Alberts and A. Rongitsch (sample preparation), and $M$. Whiticar (English).

The financial supports of the Deutsche Forschungsgemeinschaft/Bundesministerium für Forschung und Technologie are gratefully acknowledged.

\section{REFERENCES}

Bagnold, R.A., 1954. The physics of blown sand and desert dunes: London (Methuen and Co., Ltd.).

Diester-Haass, L., 1976. Late Quaternary climatic variations in North-West Africa deduced from East Atlantic sediment cores: Quat. Res., v. 6, p. 299-314.

Einsele, G. and Werner, F., 1968. Zusammensetzung, Gefüge und mechanische Eigenschaften rezenter Sedimente vom Nildelta, Roten Meer und Golf von Aden: Meteor Forsch. Ergebn., C, v. 1 , p. $21-42$.

Ericson, D.B. and Wollin, G., 1968. Pleistocene climates and chronology in deep-sea sediments: Science, v. 162, p. 1227-1234.
Folger, D.W., 1970. Wind transport of land derived mineral, biogenic and industrial matter over the North Atlantic: Deep-Sea Res., v. 17, p. $337-352$.

Gardner, J.V., 1975. Late Pleistocene carbonate dissolution cycles in the eastern equatorial Atlantic. In Dissolution of Deep-Sea Carbonates, Spec. Publ. 13, Cushman Found. Foram. Res., p. $129-141$.

Kögler, F.C., 1963. Das Kastenlot: Meyniana, v. 13, p. 1-7. 1974. Sediment-physical properties of three deep-sea cores from the Central Pacific Ocean: Meerestechnik mt, v. 5, 6, p. 199-201.

Michel, P., 1973. Les bassins des fleuves Sénégal et Gambie. Etude géomorphologique: Mém. ORSTOM, No. 63, Paris.

Richards, A.F., 1961. Investigations of deep-sea sediment cores. 1. Shear strength, bearing capacity and consolidation: U.S. Navy Hydrographic Office, Tech. Rept. 63, p. 1-70. 1962. Investigations of deep-sea sediment cores. 2. Mass physical properties: U.S. Hydrographic Office, Tech. Rept. 106, p. $1-145$.

Rupke, N.A., Stanley, D.J., and Stuckenrath, R., 1974. Late Quaternary rates of abyssal mud deposition in the western Mediterranean Sea: Mar. Geol., v. 17, p. M9-M16.

Sancetta, O., Imbrie, J., and Kipp, N.G., 1973. Climatic record of the past 130,000 years in North Atlantic deep-sea core V 23-82: correlation with the terrestrial record: Quat. Res., v. 3, p. 110116.

Sarnthein, M., 1971. Oberflächensedimente im Persischen Golf und Golf von Oman. II Quantitative Komponentenanalyse der Grobfraktion: Meteor Forsch. Ergebn., C, v. 5, p. 1-113.

Sarnthein, M. and Walger, E., 1974. Der äolische Sandstrom aus der West-Sahara zur Atlantikküste: Geol. Rundschau, v. 63, p. 1065-1087.

Skempton, A.W., 1953. The colloidal activity of clays: Third Internat. Conference of Soil Mechanics and Foundation Engineering, v. 1, p. 57-61, Zürich. 
$*=$ minor lithology

SMEAR SLIDE SUMMARY

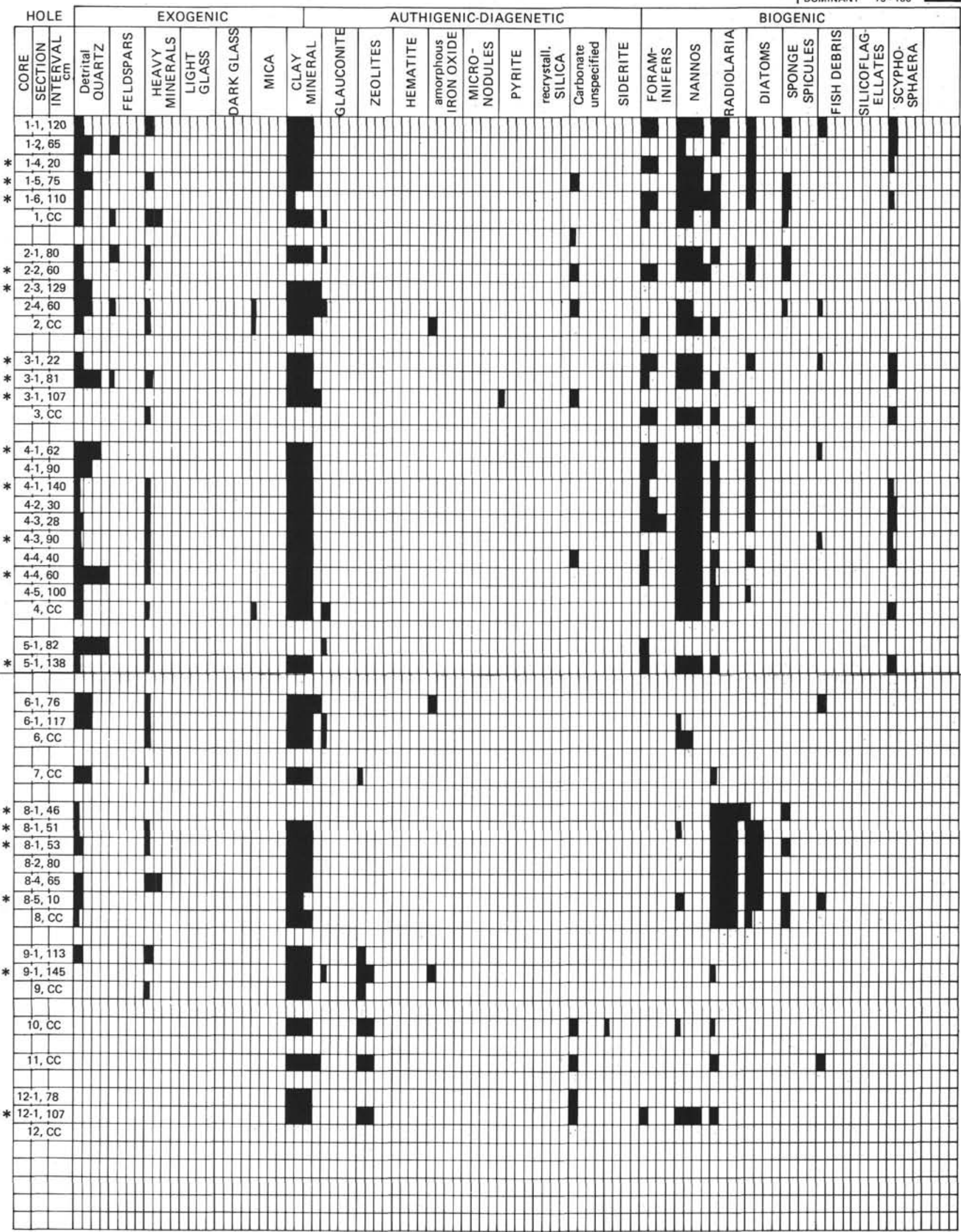

SITE 367 Page 1 of 3

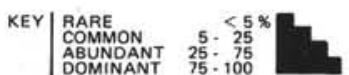




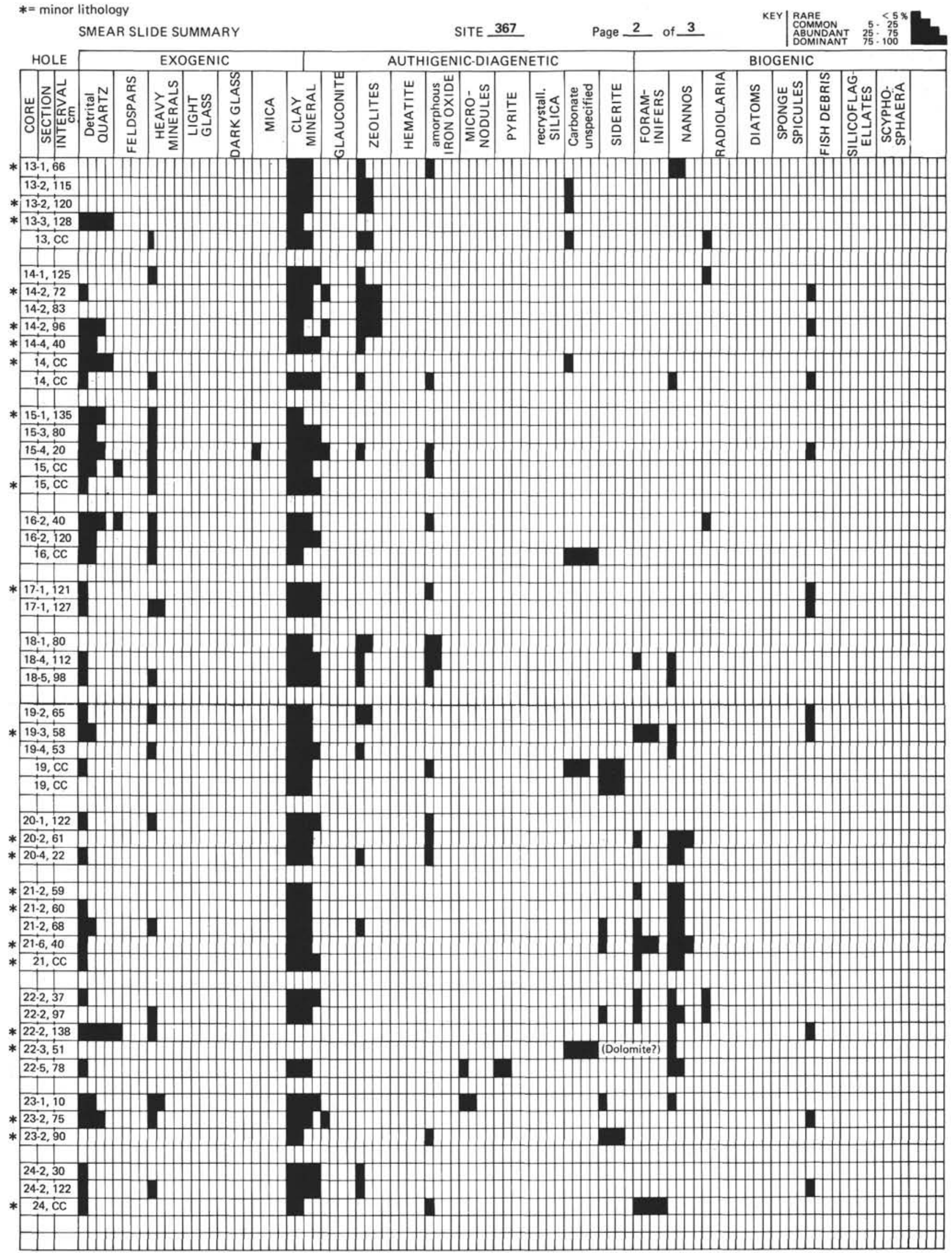


*= minor lithology

SMEAR SLIDE SUMMARY

SITE $\underline{367} \quad$ Page 3 of $\underline{3}$

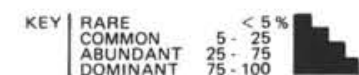

\begin{tabular}{|c|c|c|c|c|}
\cline { 2 - 4 } HOLE & AUTHIGENIC-DIAGENETIC & BIOGENIC
\end{tabular}

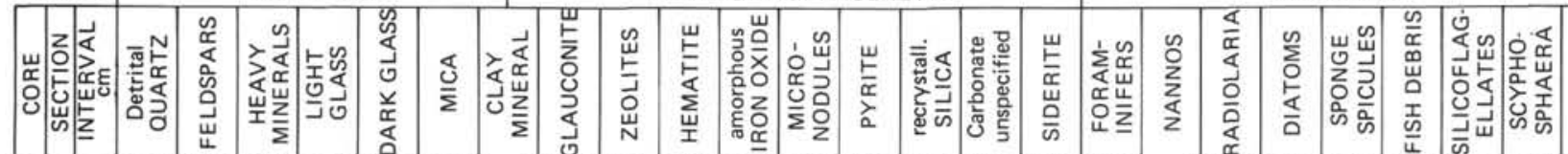

* $25-3,39$

\begin{tabular}{|r|}
$25-3,70$ \\
\hline $25,1 \mathrm{CC}$ \\
\hline
\end{tabular}

$\frac{1}{26-1,60}$

* $\frac{26-2,40}{26, \mathrm{CC}}$

$* \frac{1}{27-1,131}$

$27 \cdot 2,138$

*

-
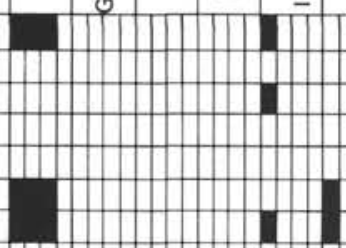

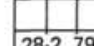

* $\frac{28-2,7}{28-2,2}$

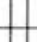
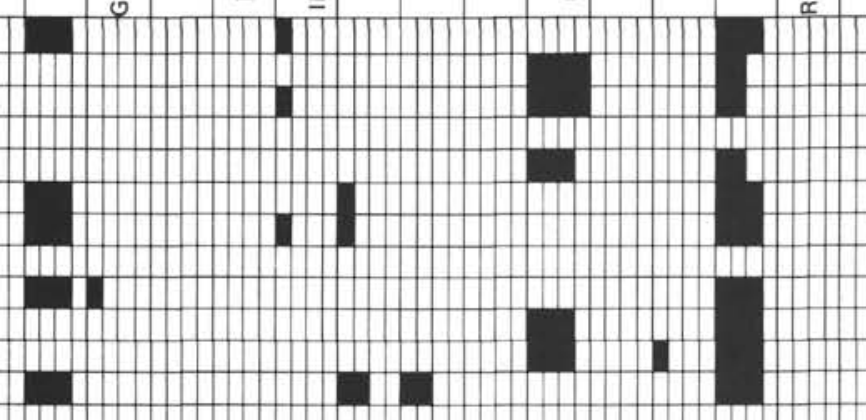

$* \frac{29-1,118}{29-1,55}$
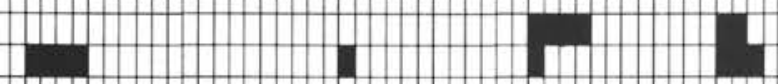

*

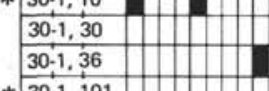

* 30-1, 101

* $30-2,133$

$30, \mathrm{cc}$

31-1, 28

$31 \cdot 1,70$

31. Cc

* $\frac{1}{32-2,43}$

$32 \cdot 2,47$

\begin{tabular}{l}
1,1 \\
\hline $32-3,29$ \\
\hline $32,3,24$
\end{tabular}

* $32-3,24$

\begin{tabular}{|l|}
\hline $32-5,97$ \\
\hline $32, \mathrm{cC}$ \\
\hline
\end{tabular}

$1+1+$
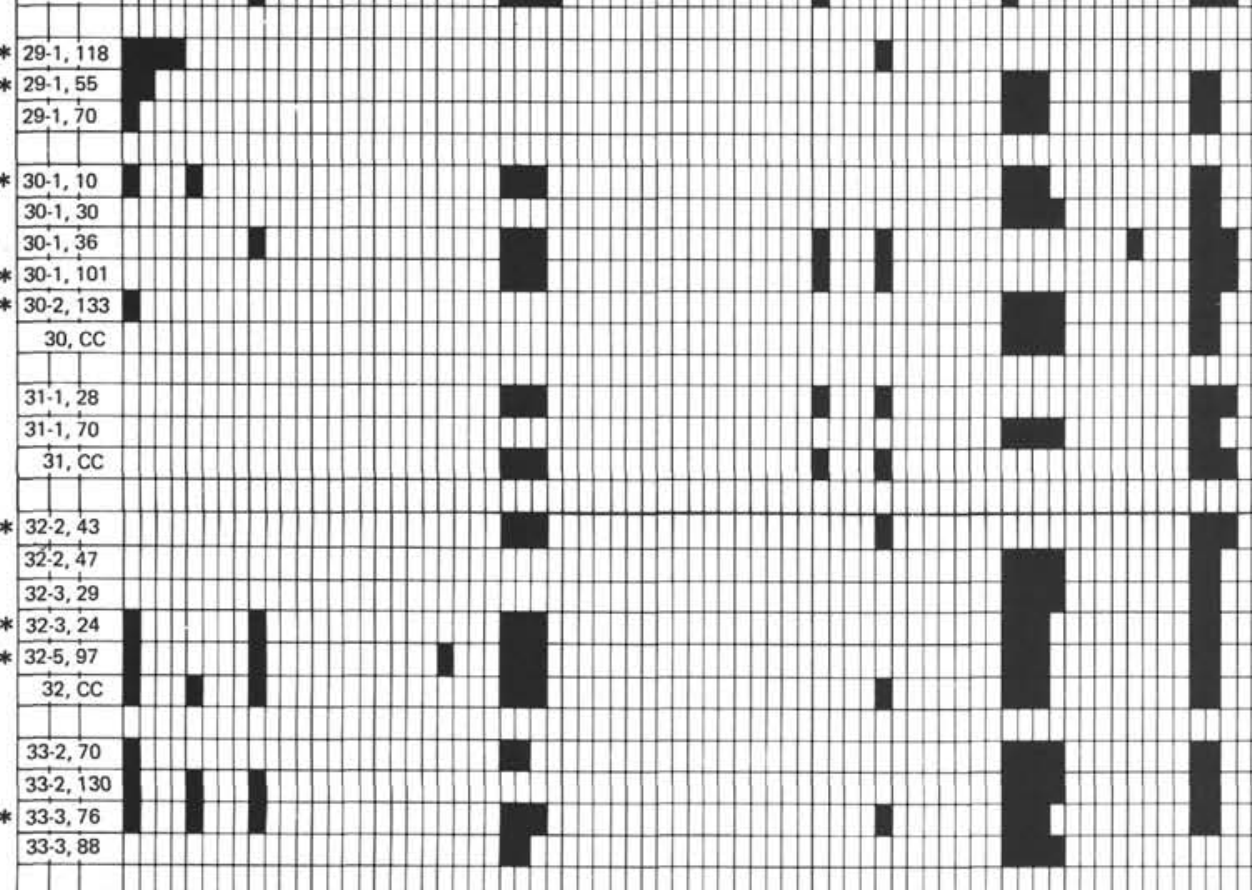

1 1010

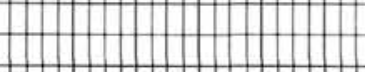

1 1010 


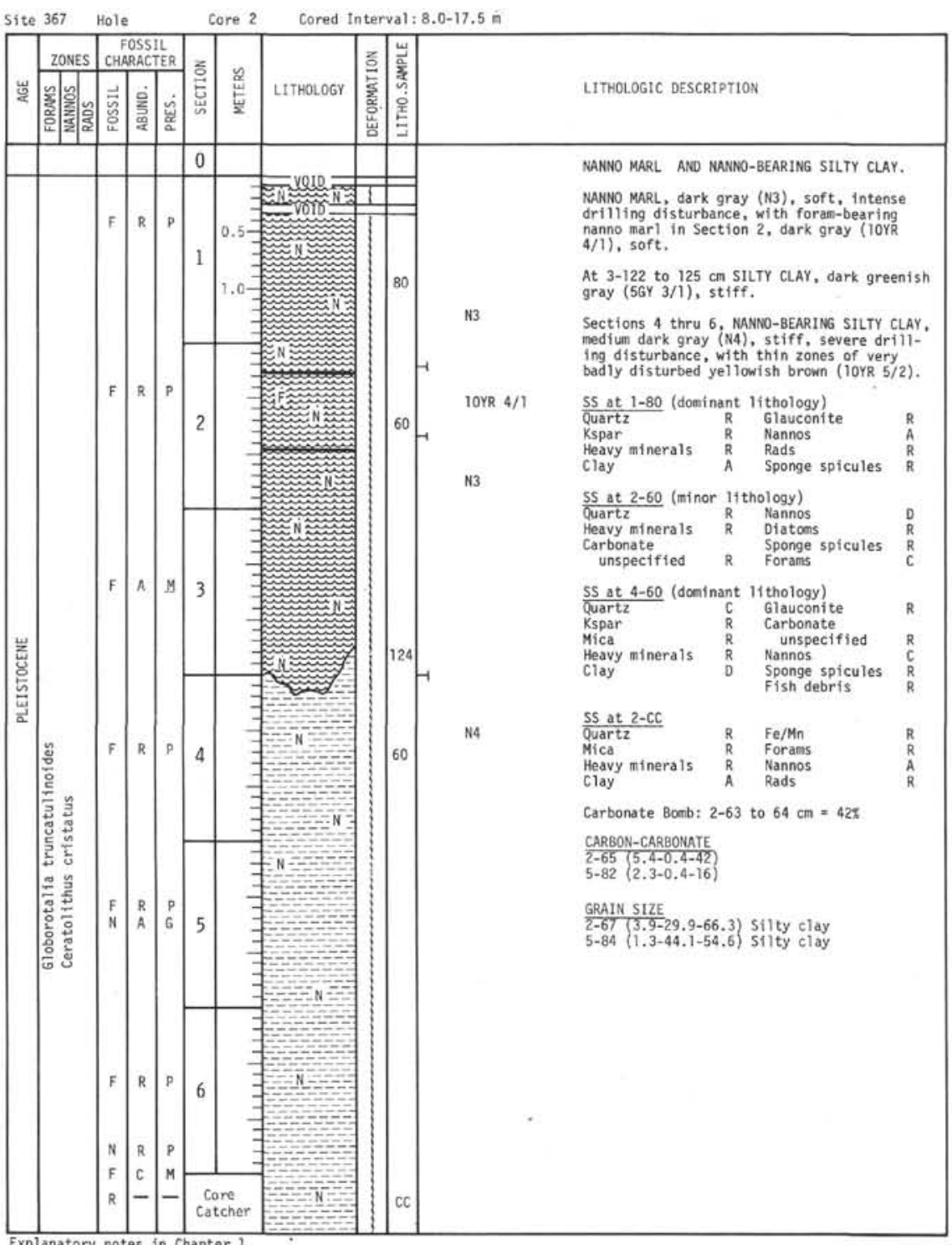




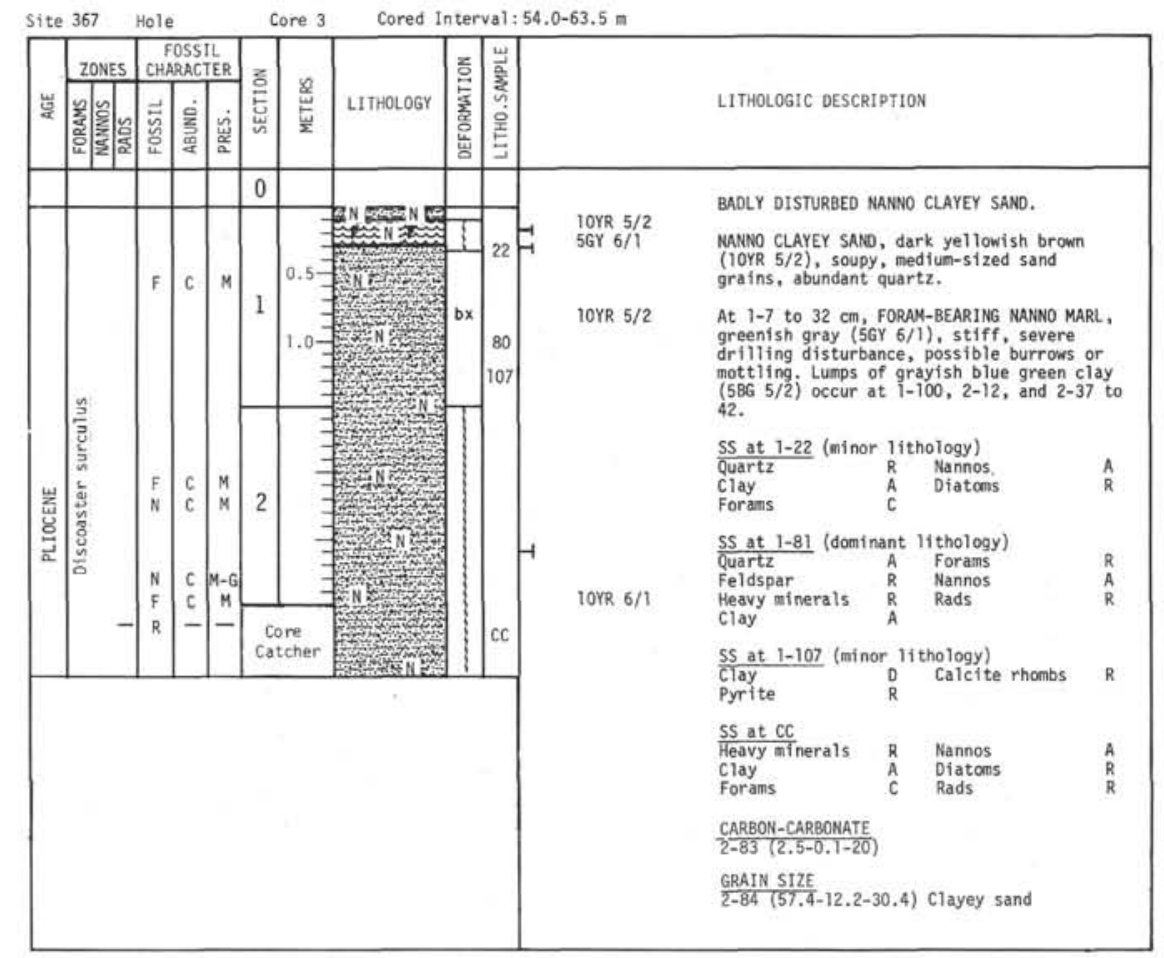

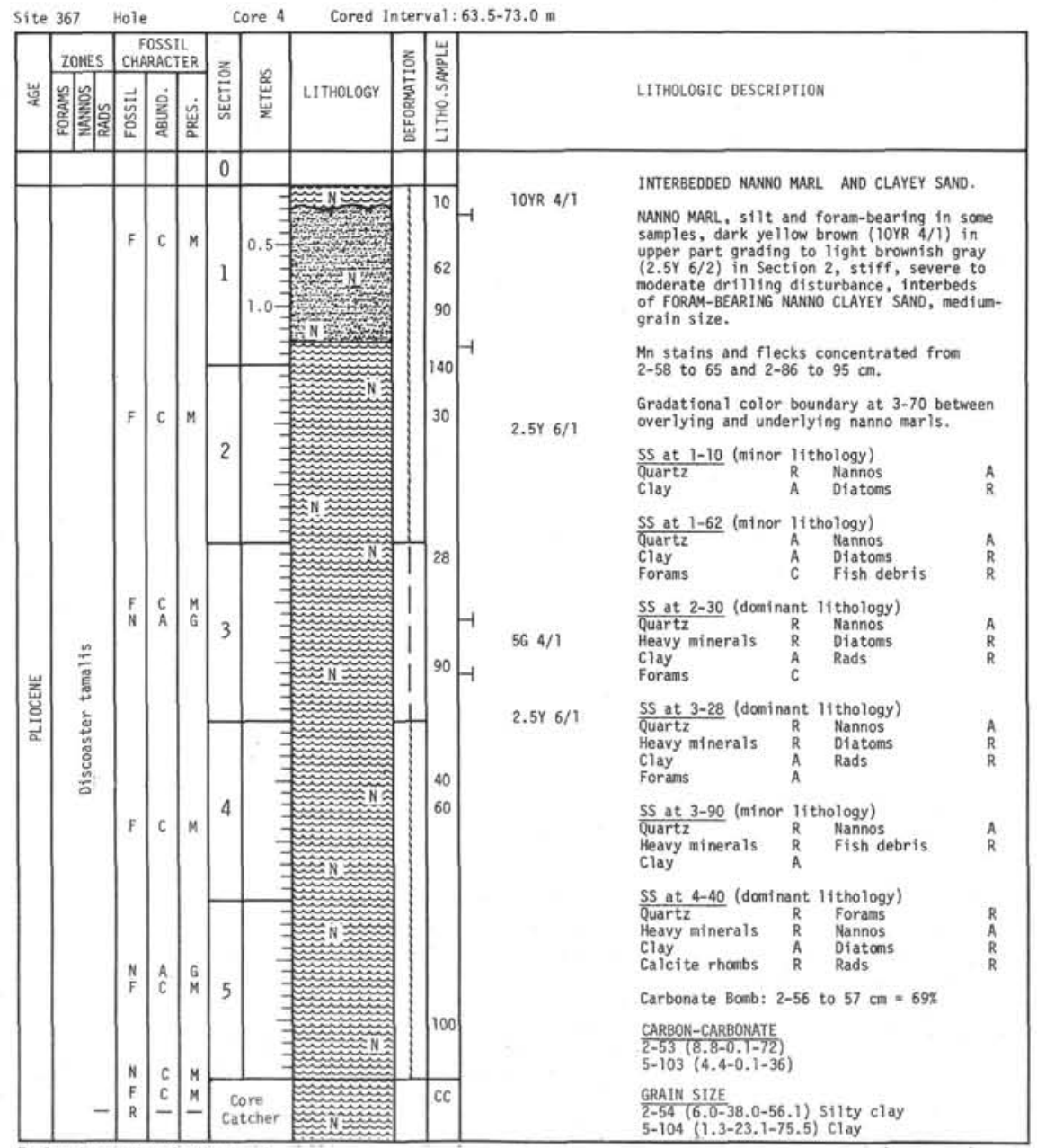




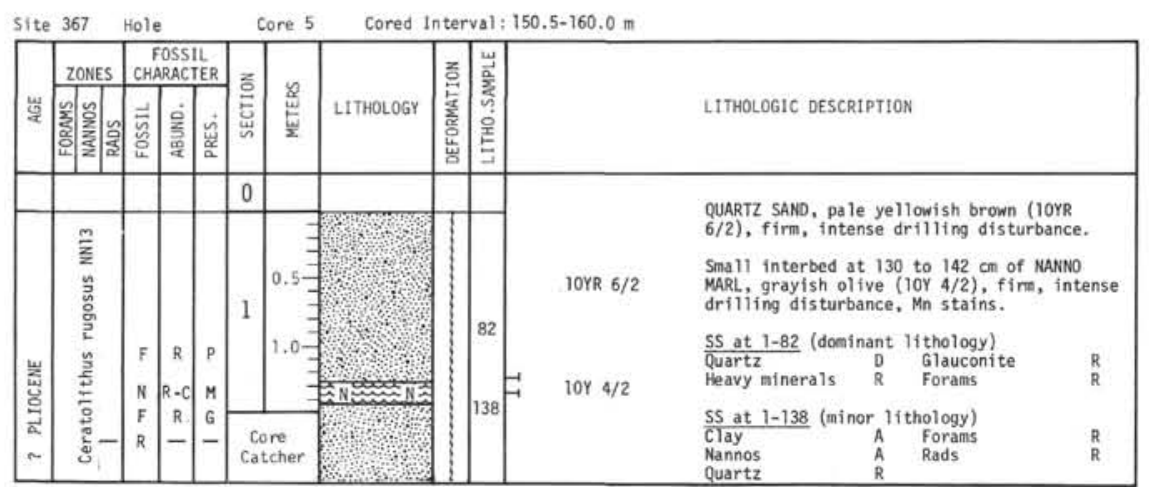

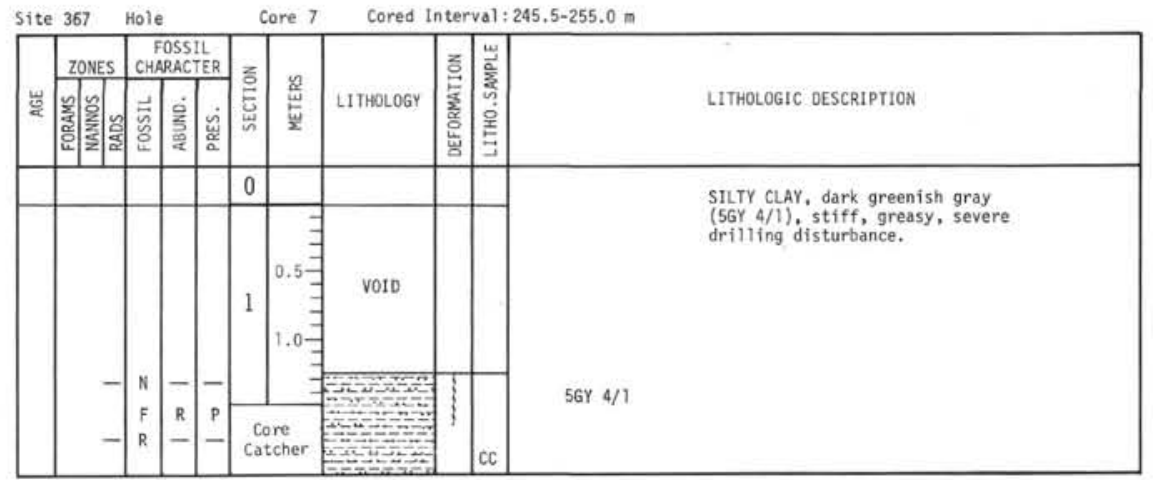

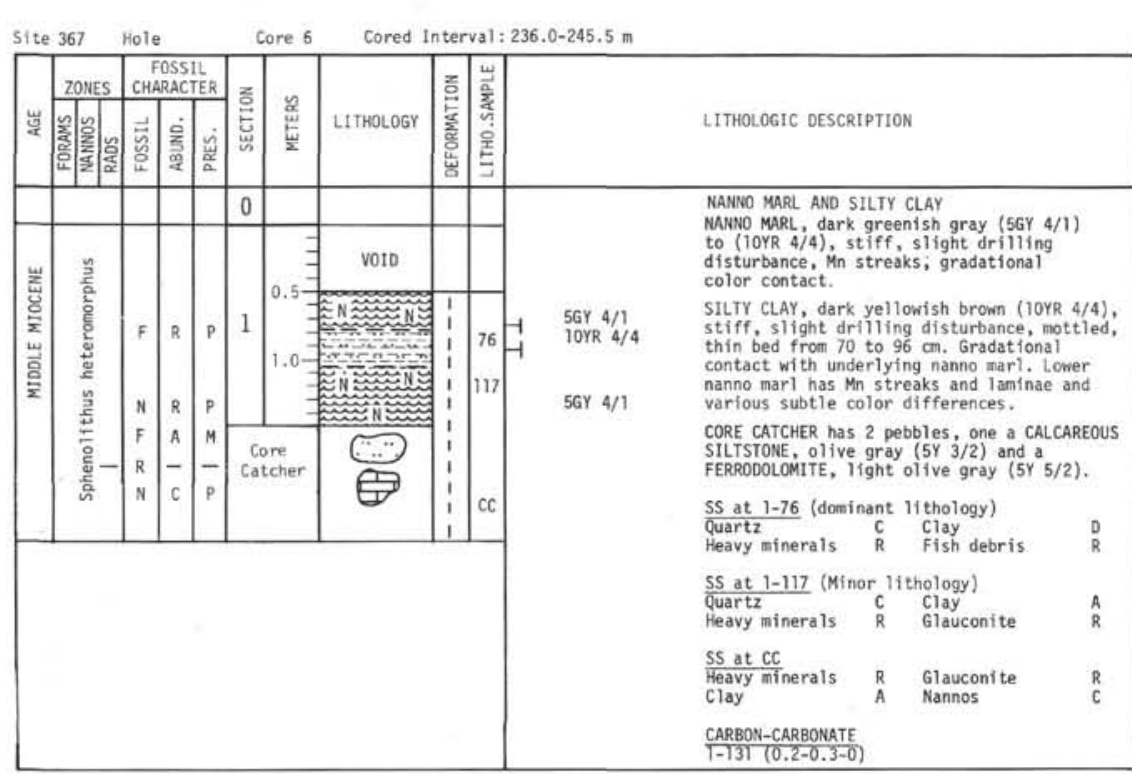

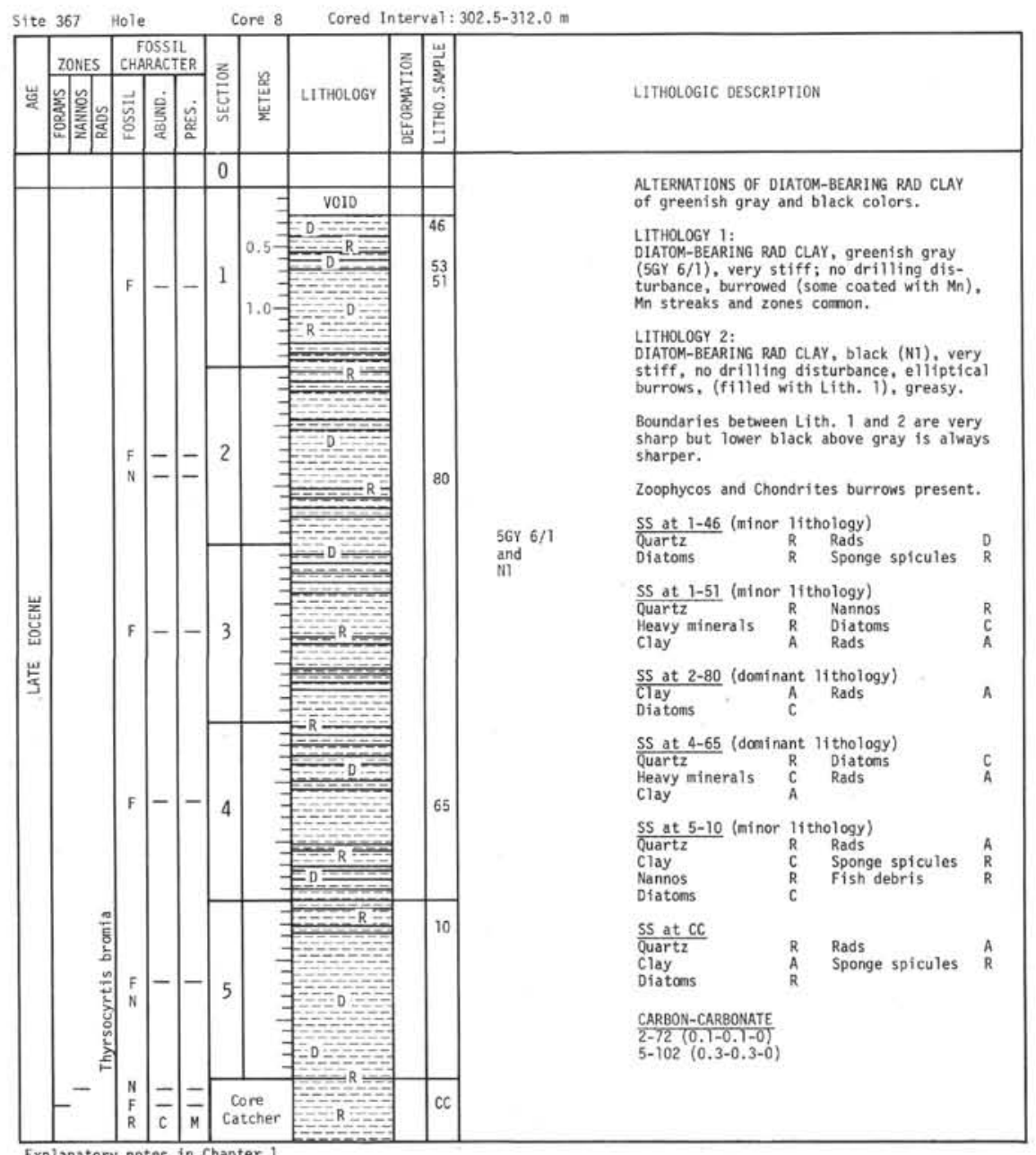




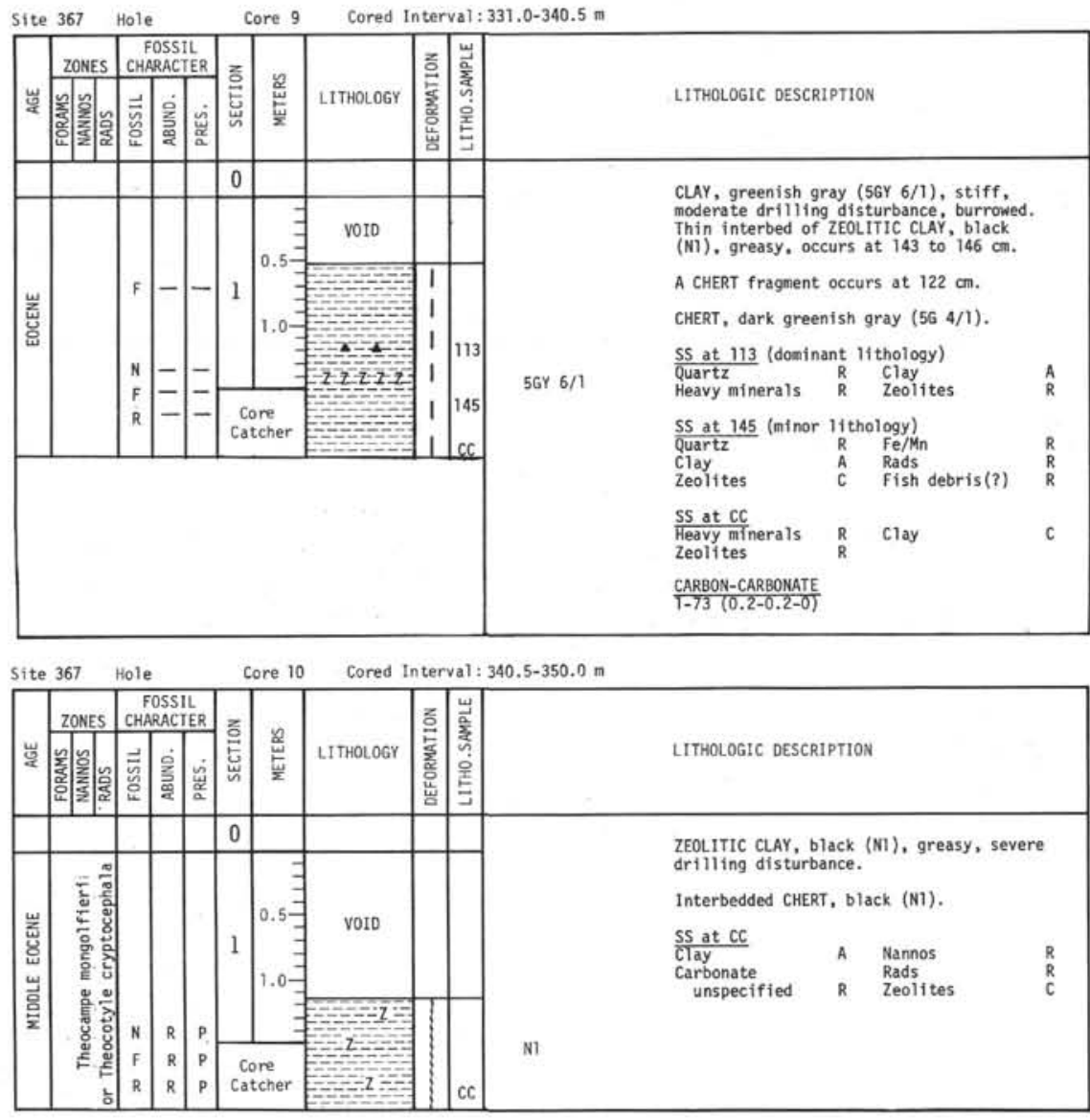

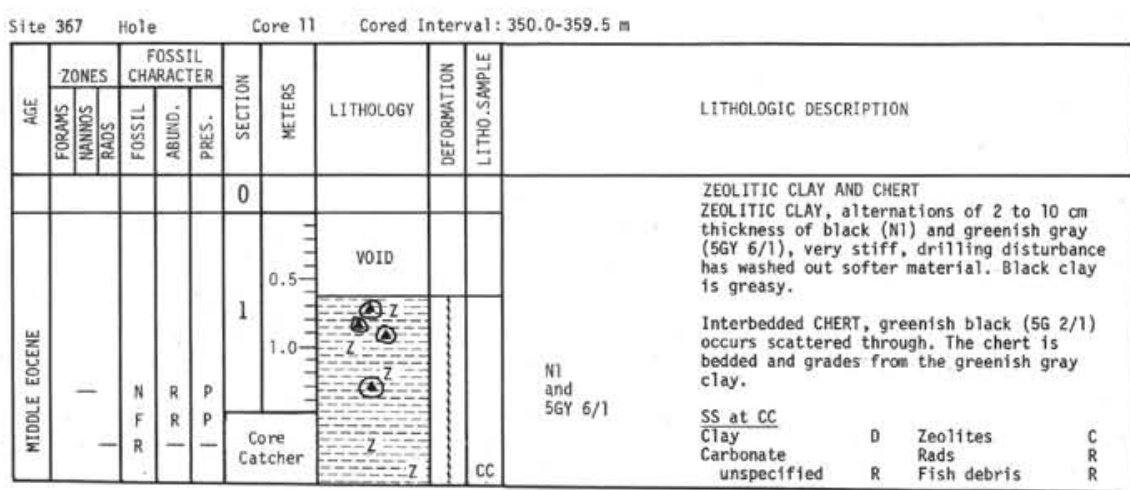

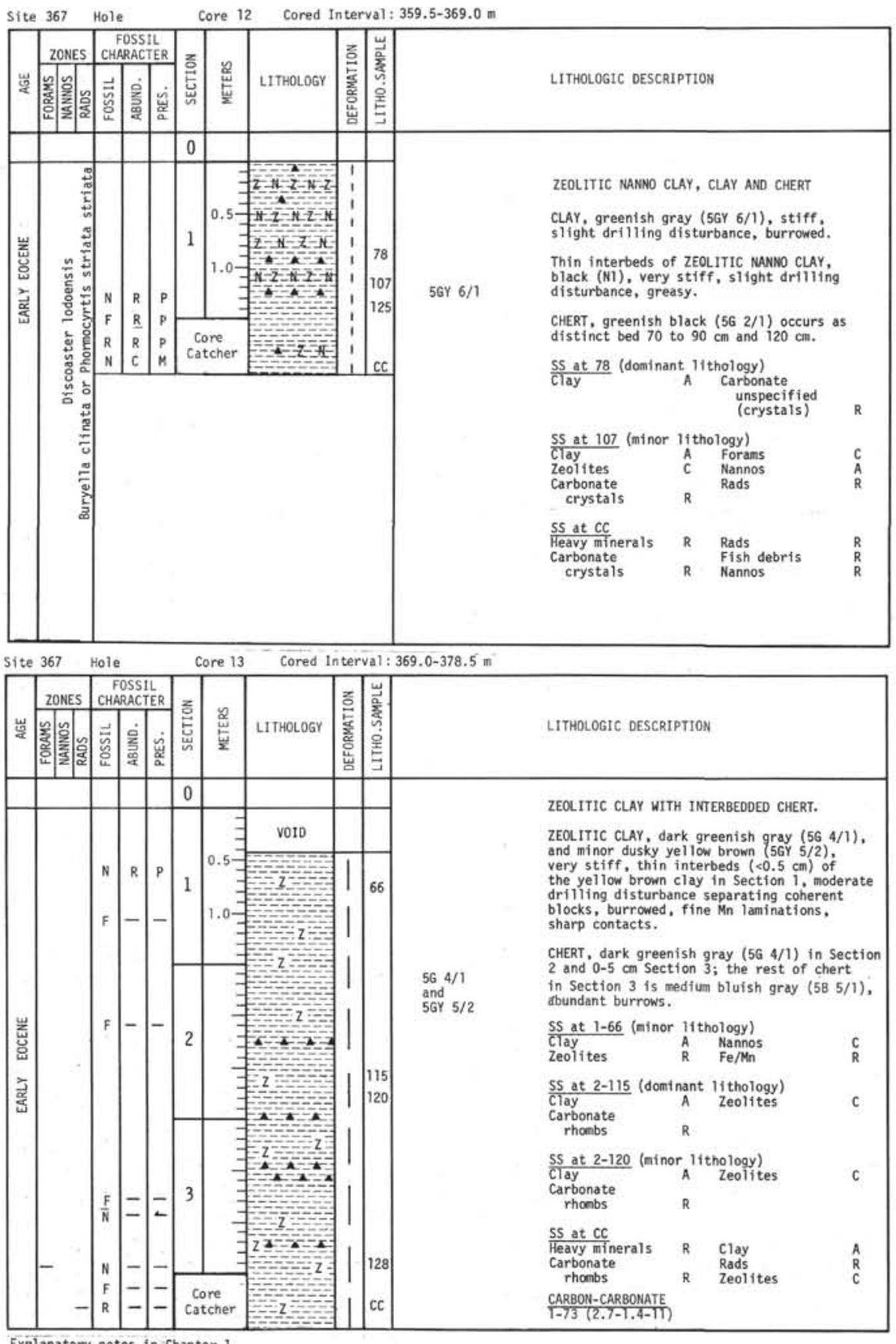




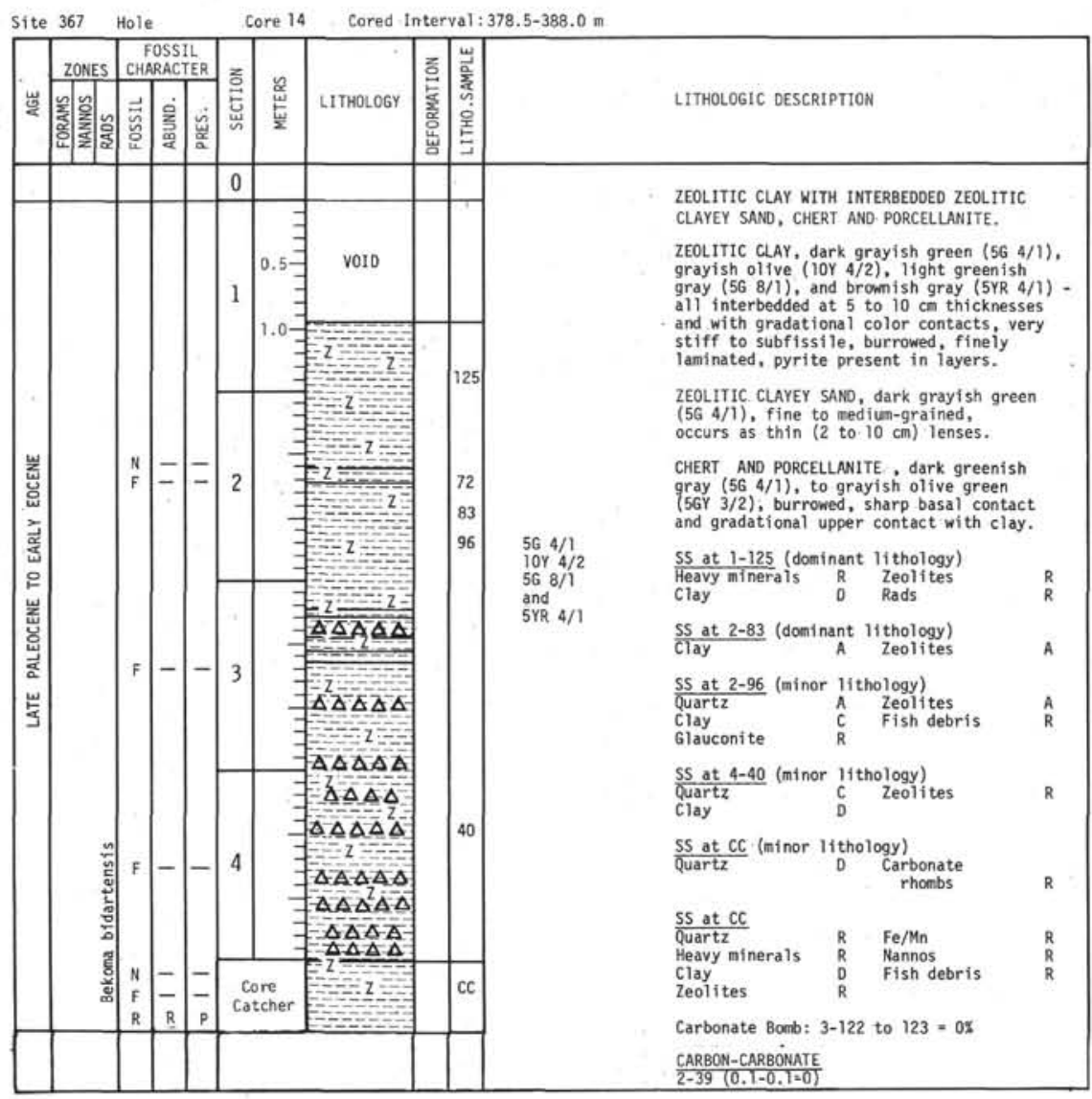

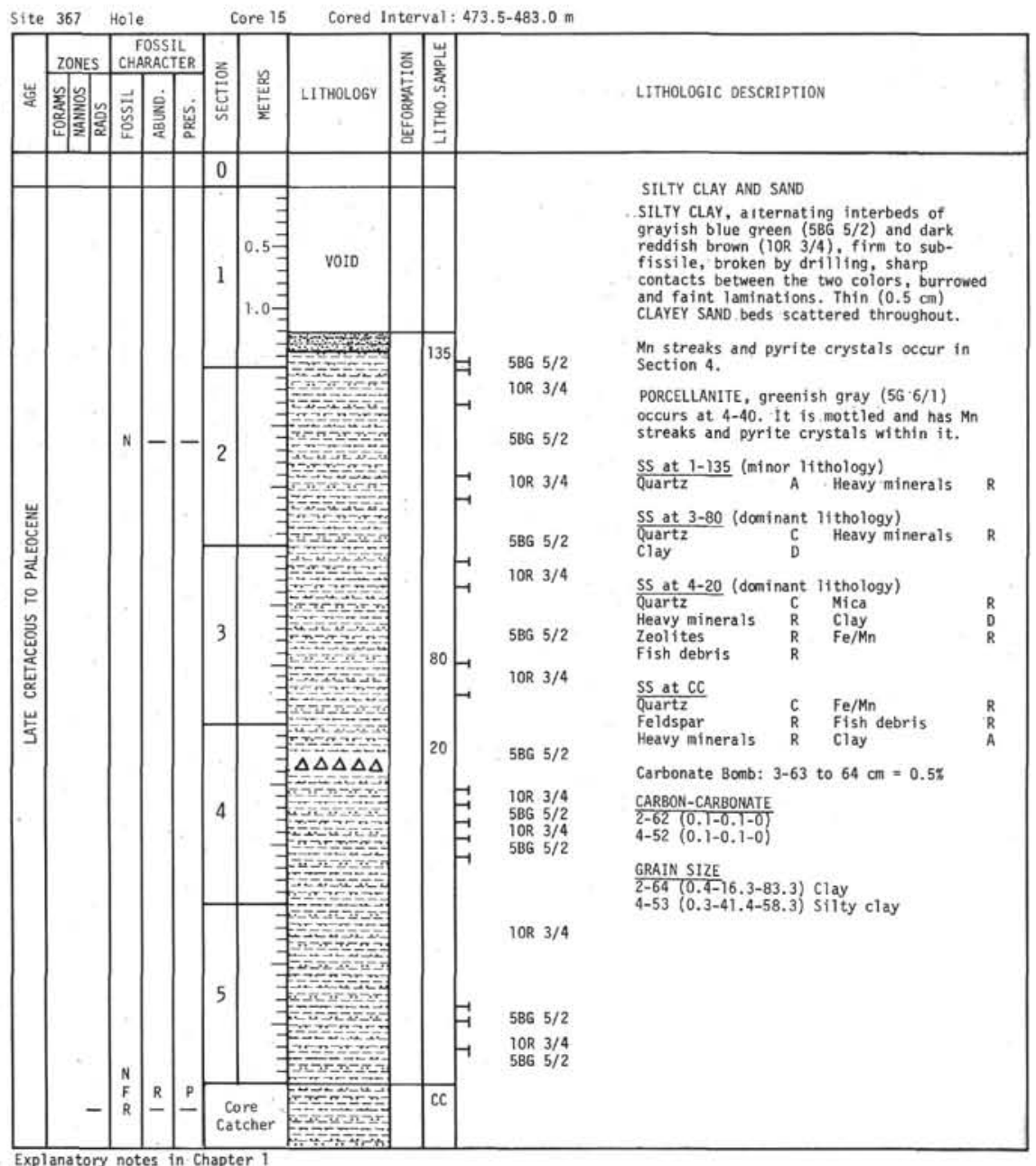




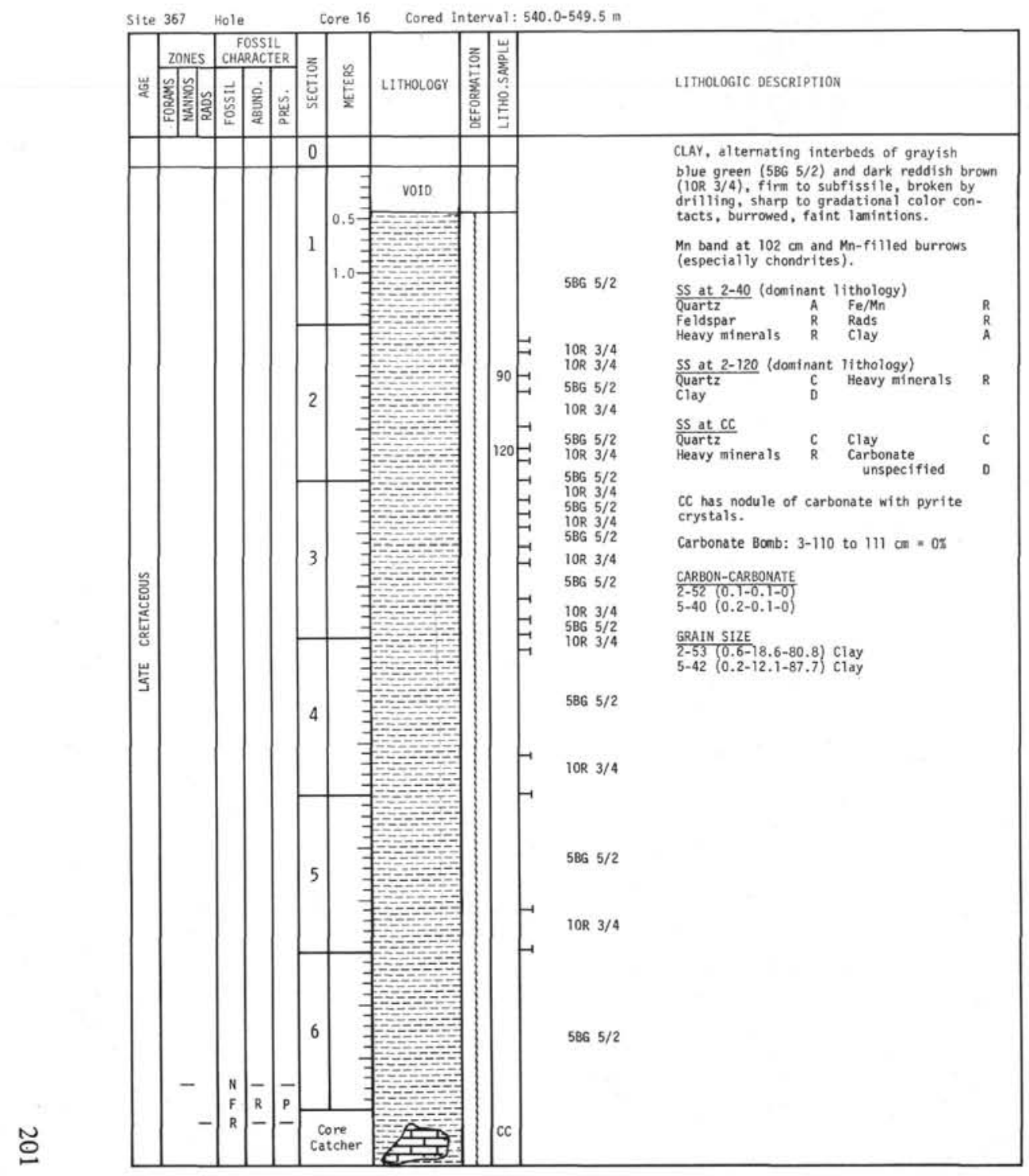

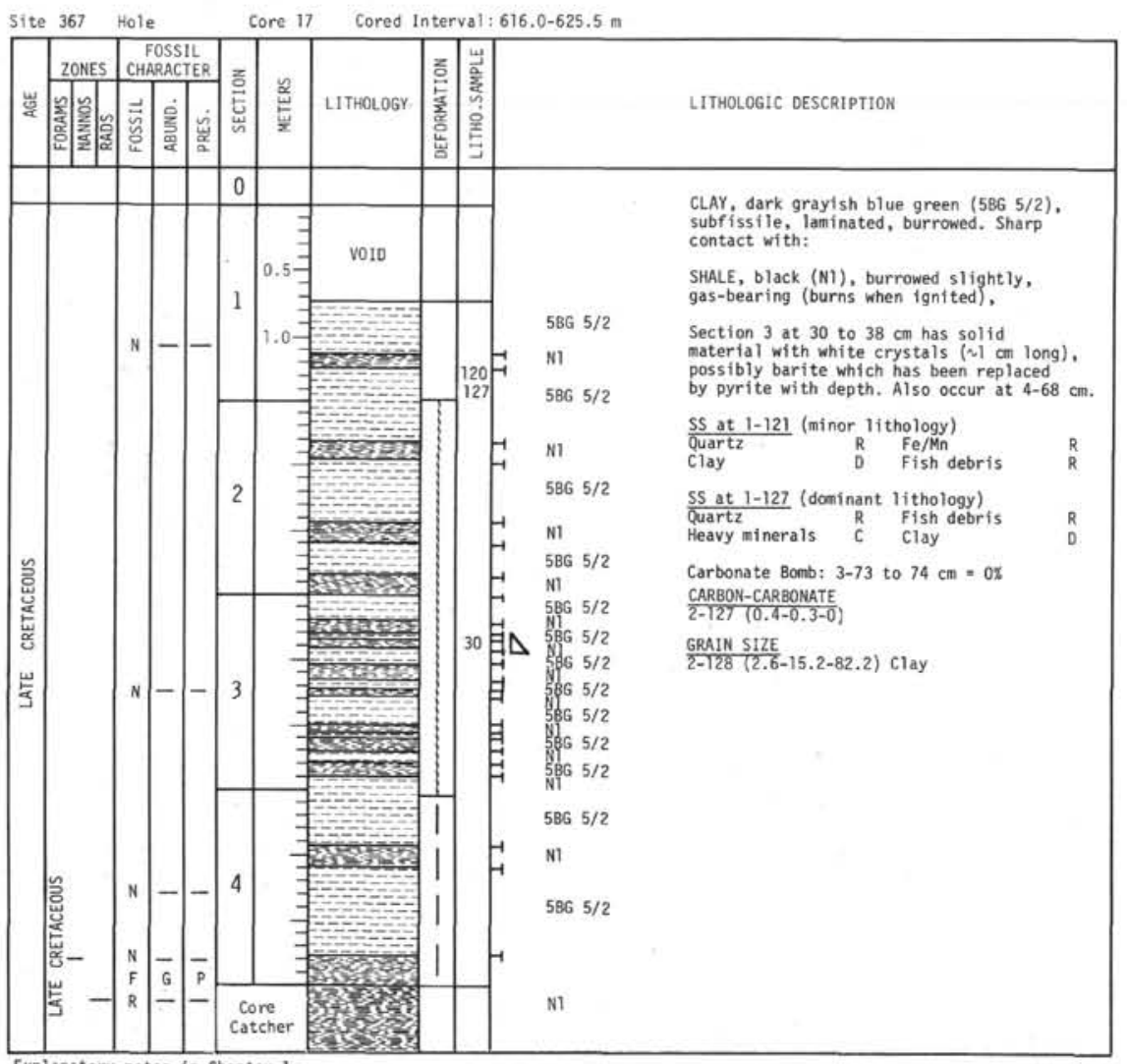




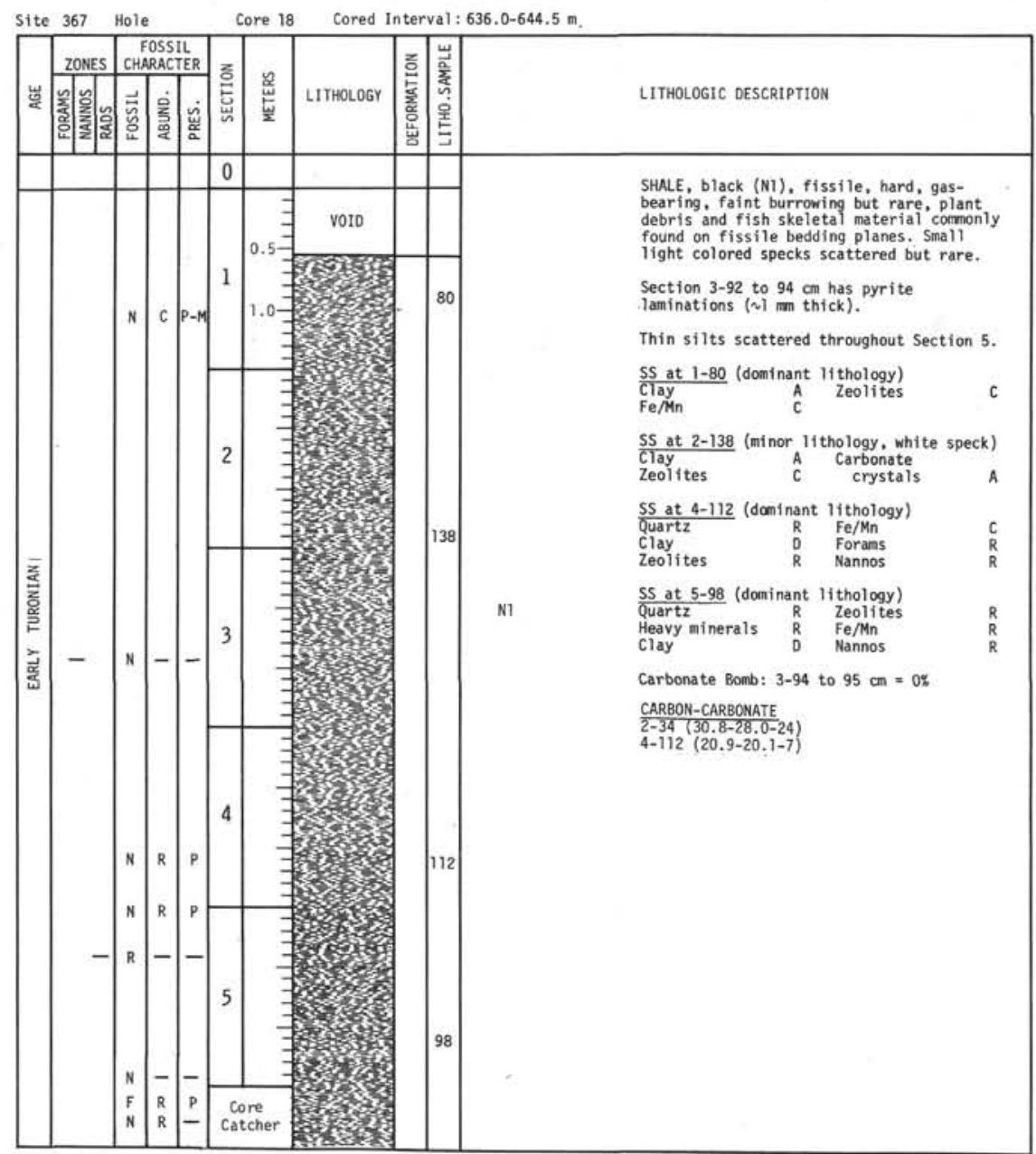

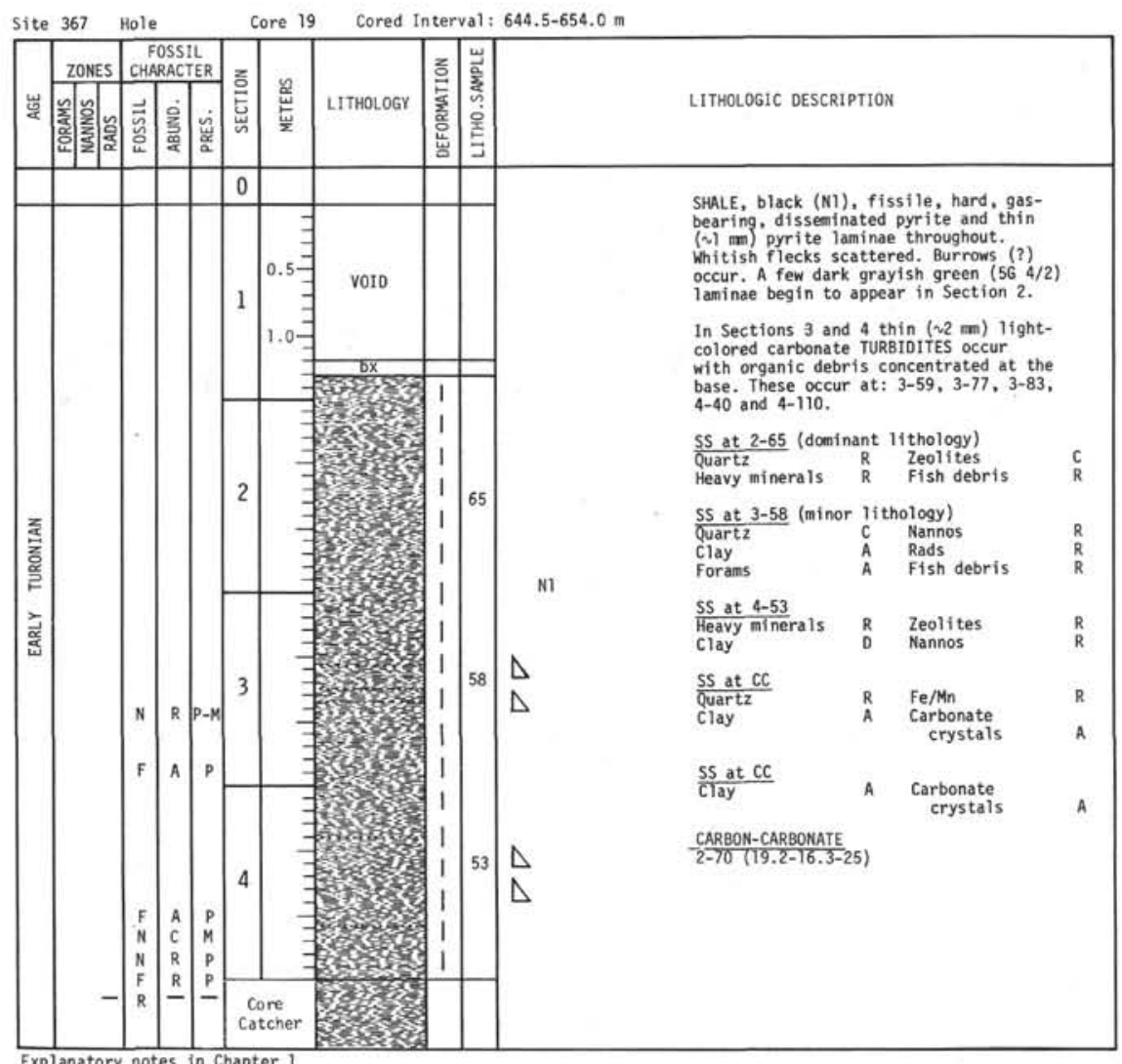




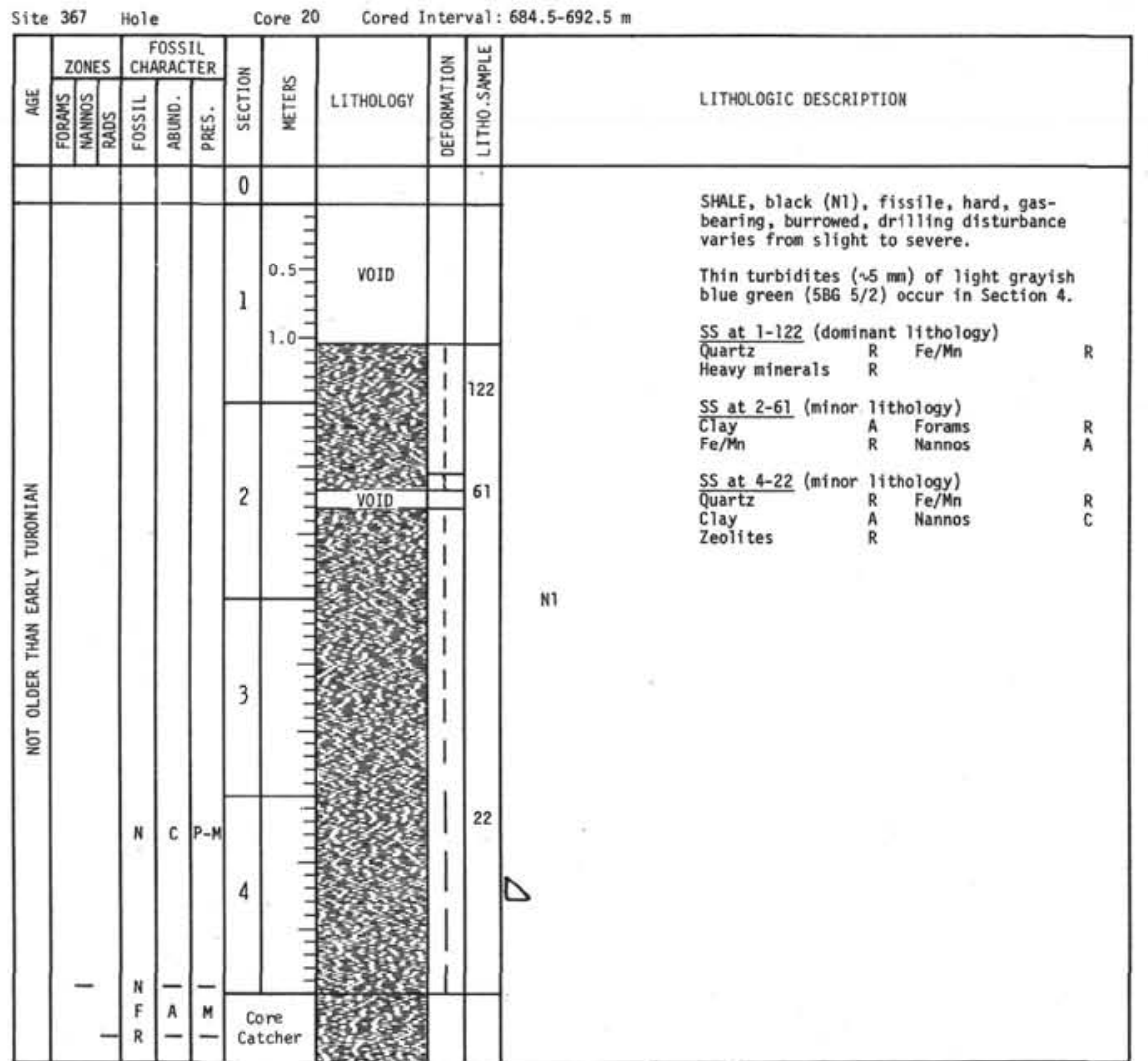

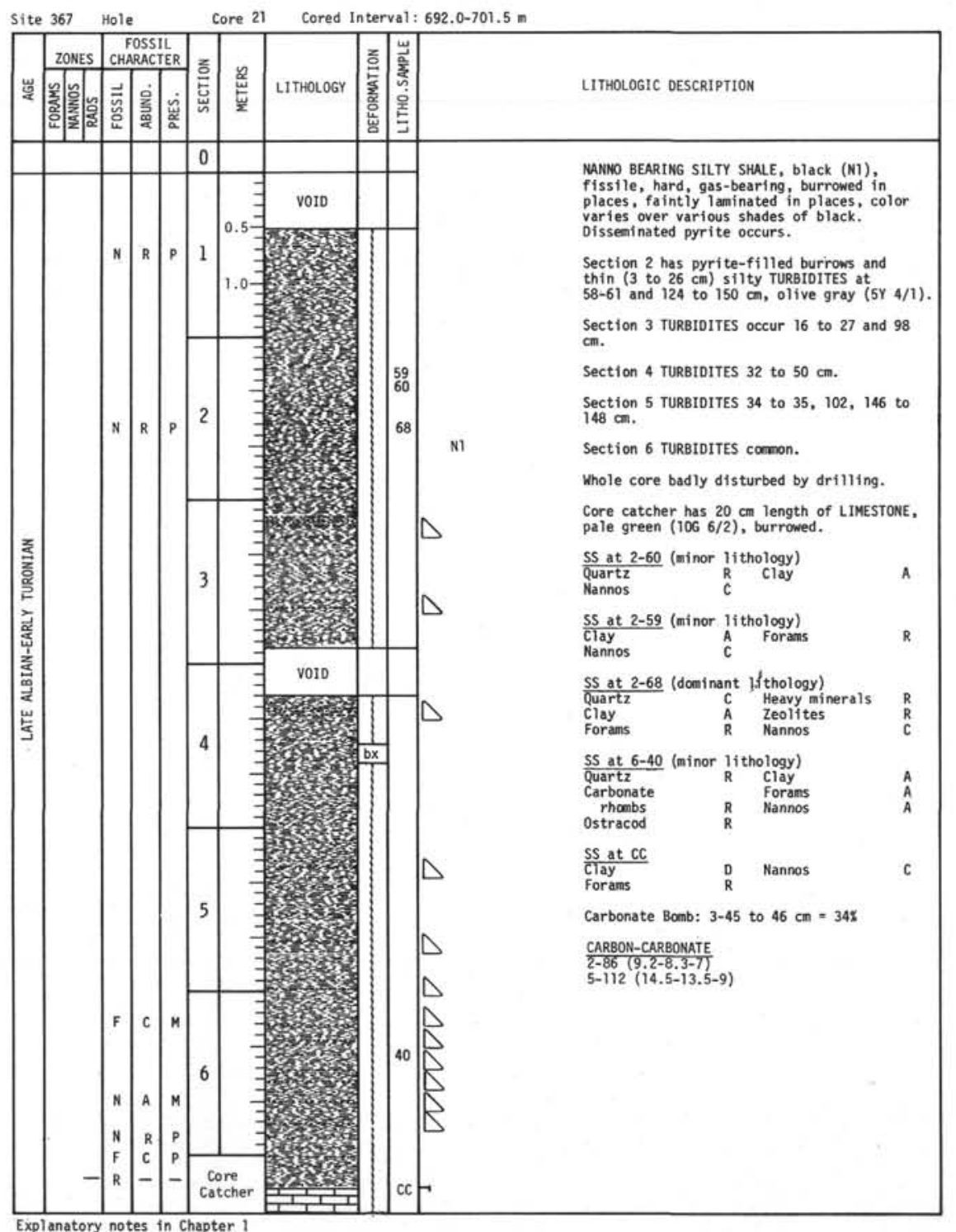




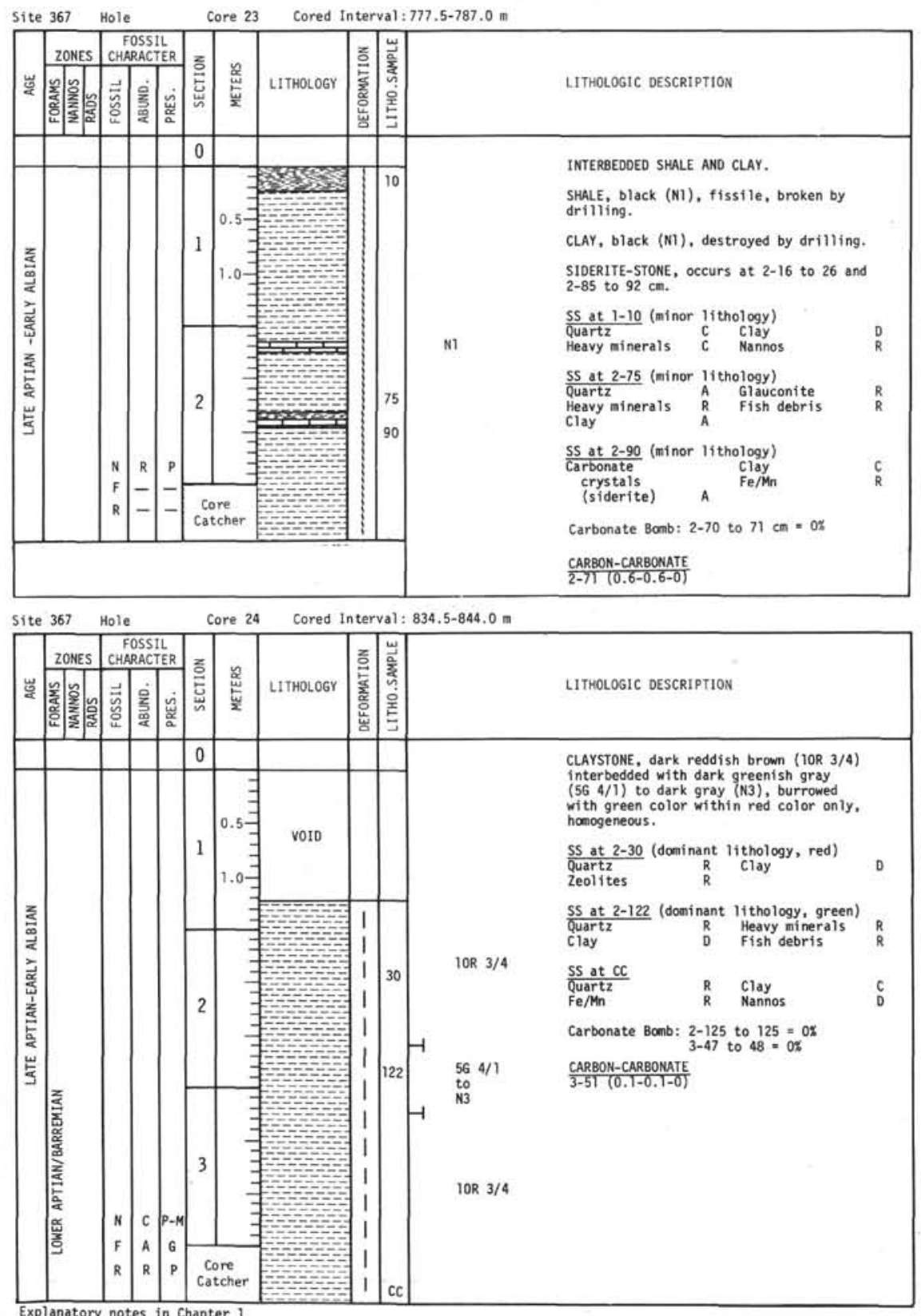




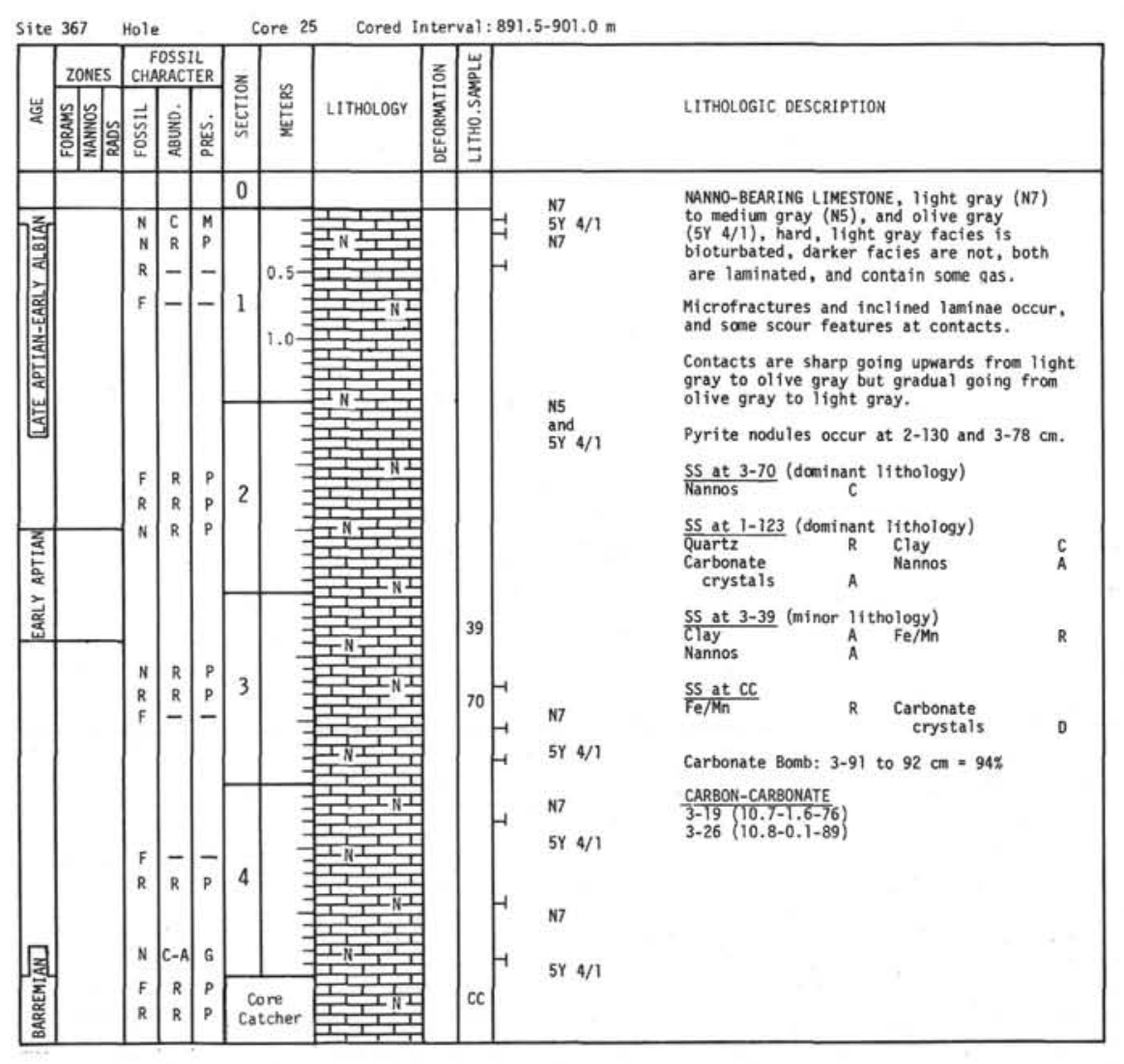

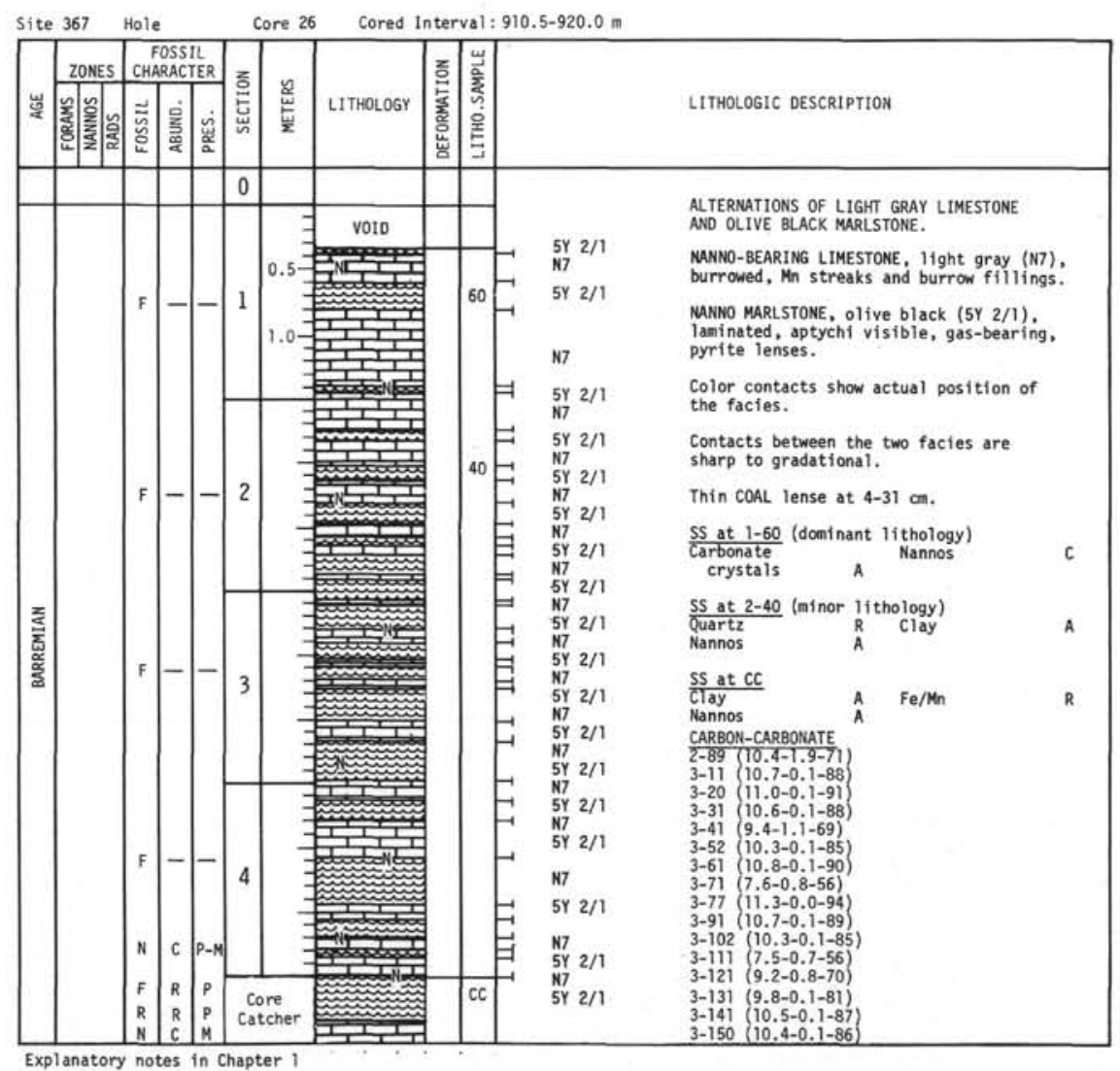




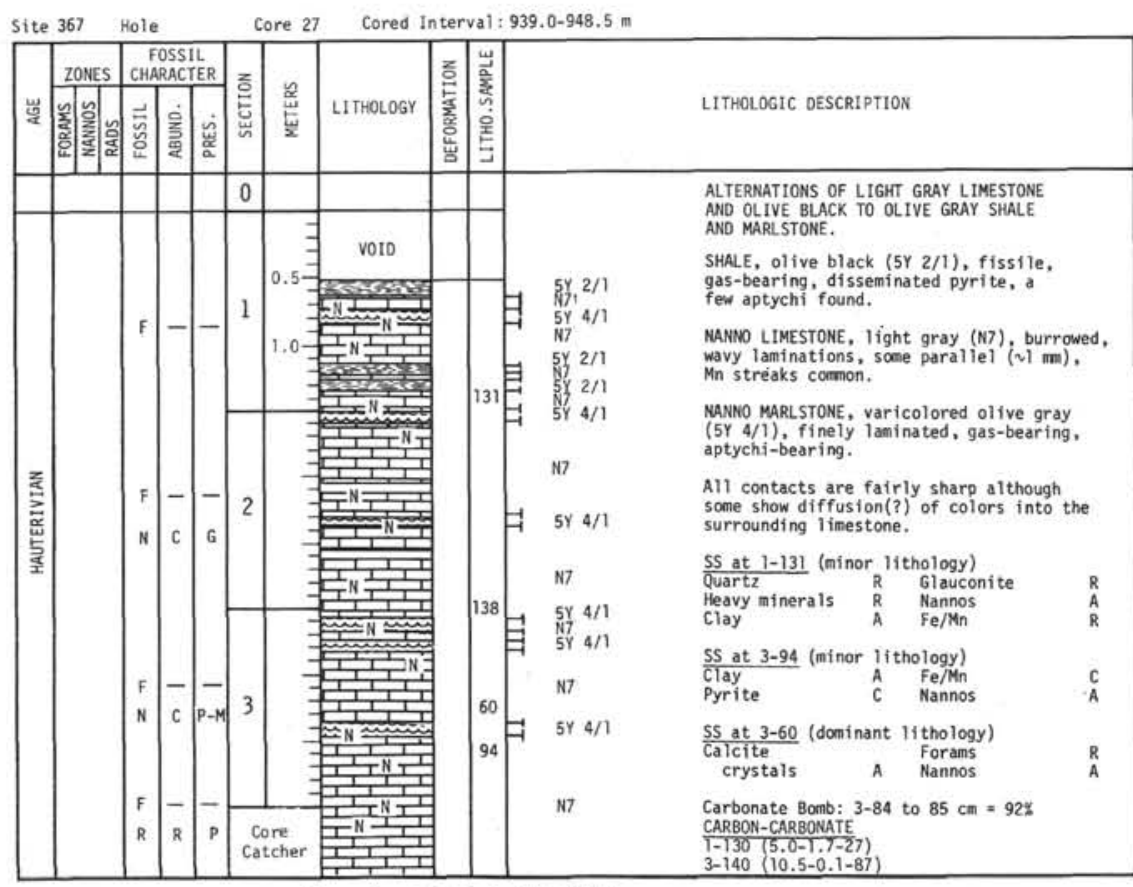

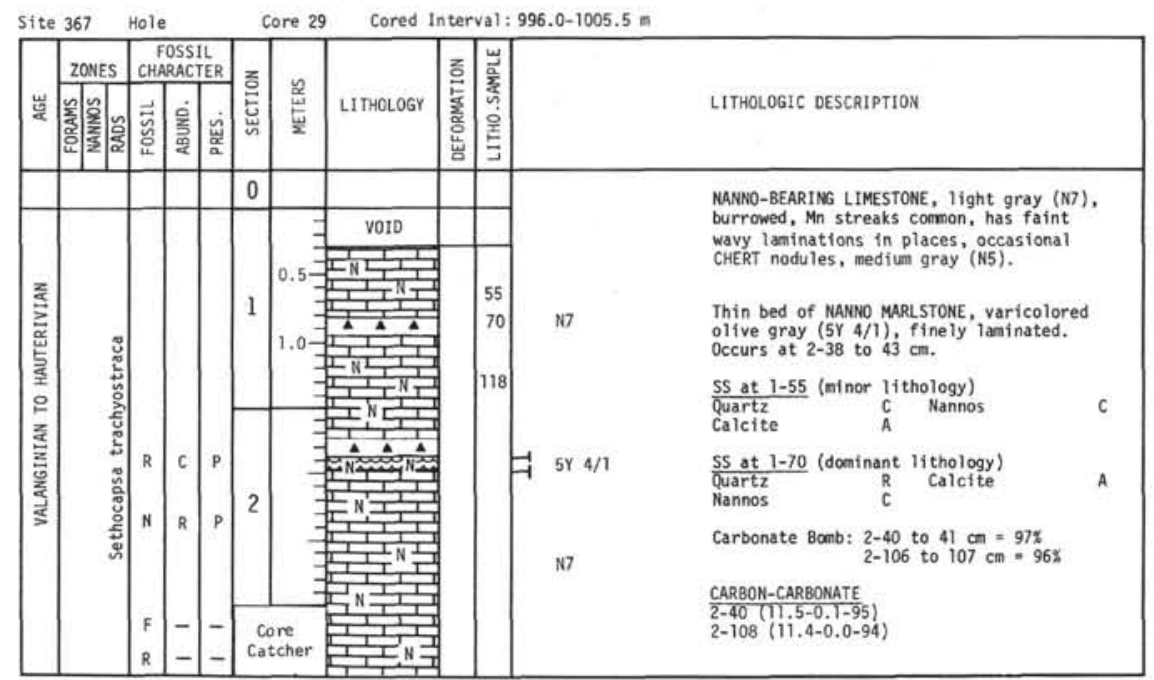

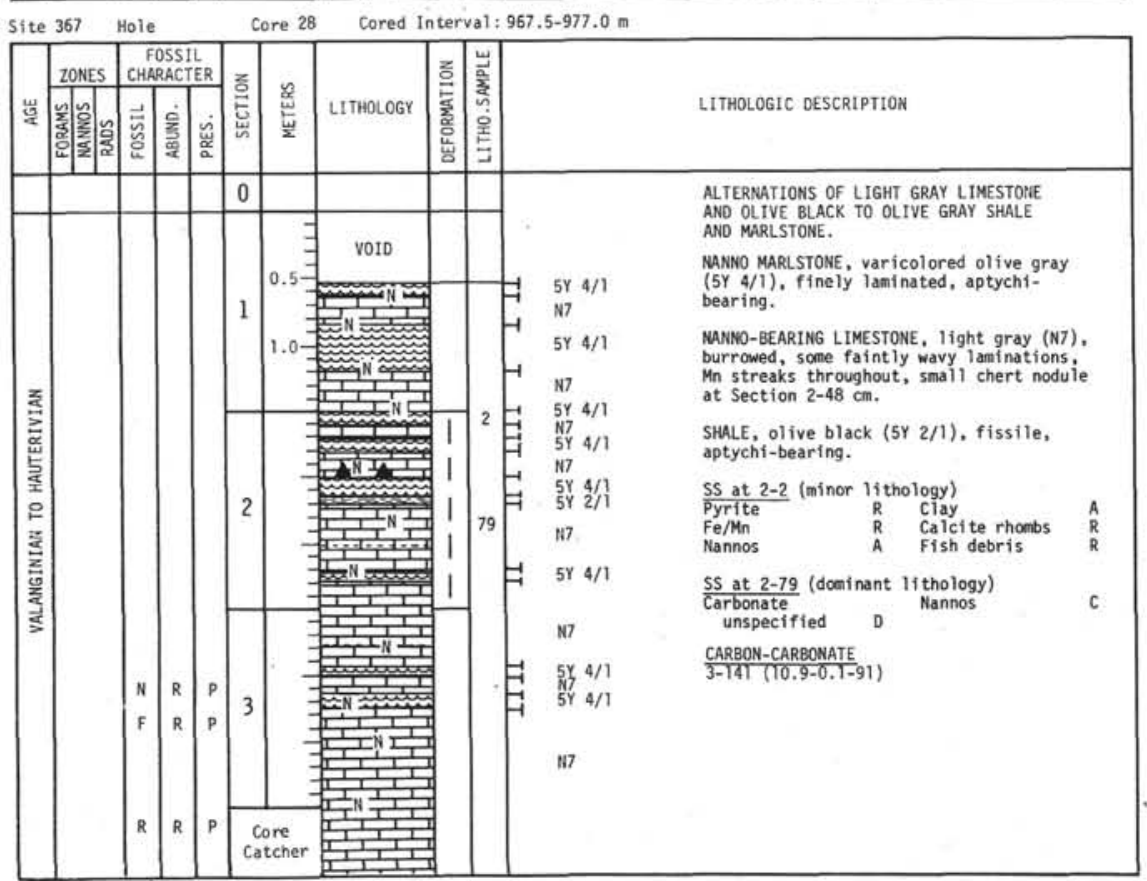

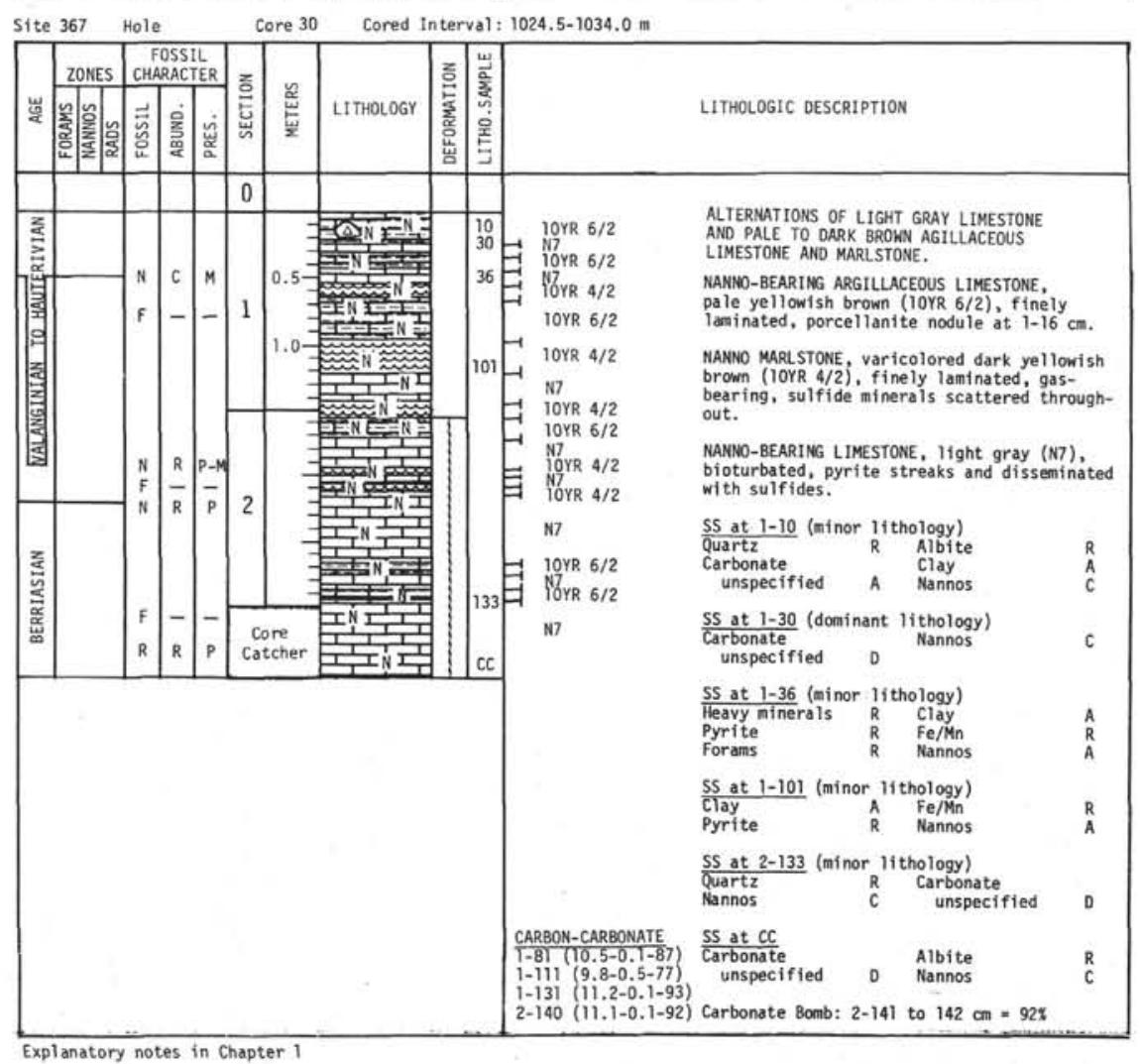




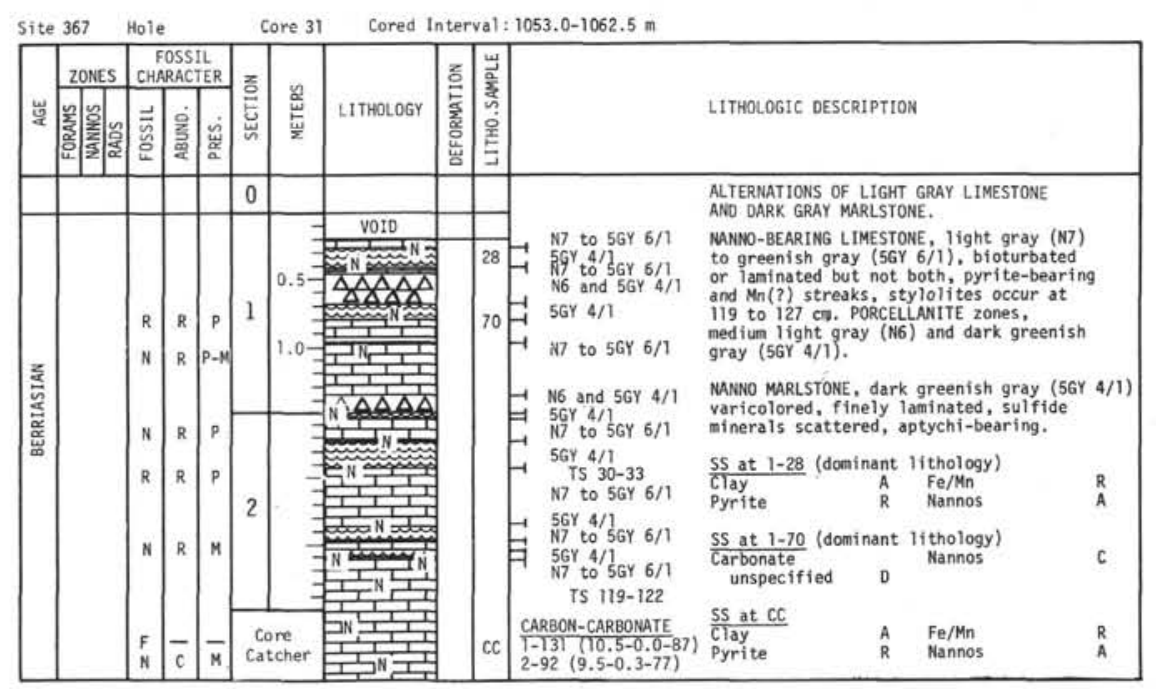

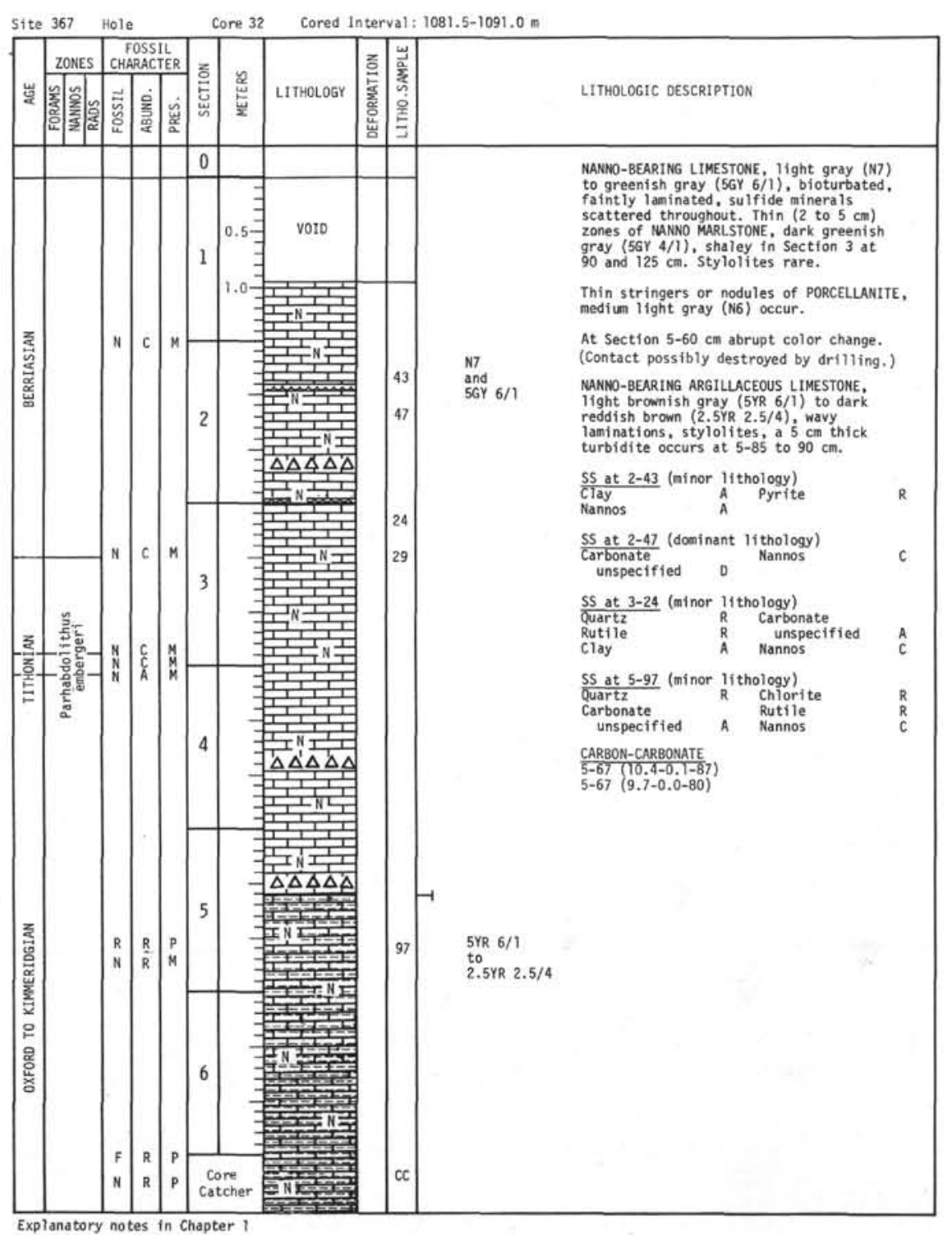






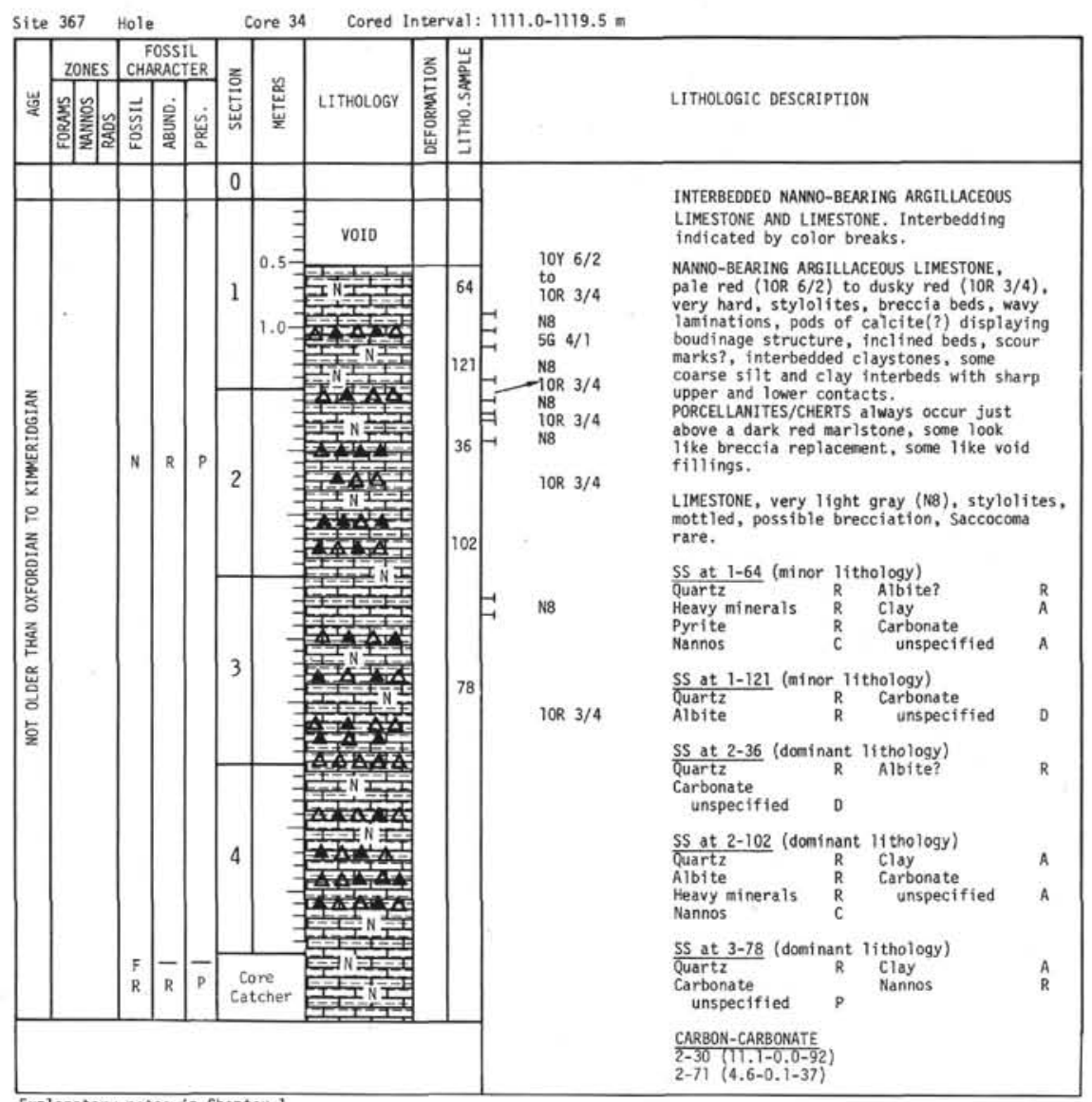




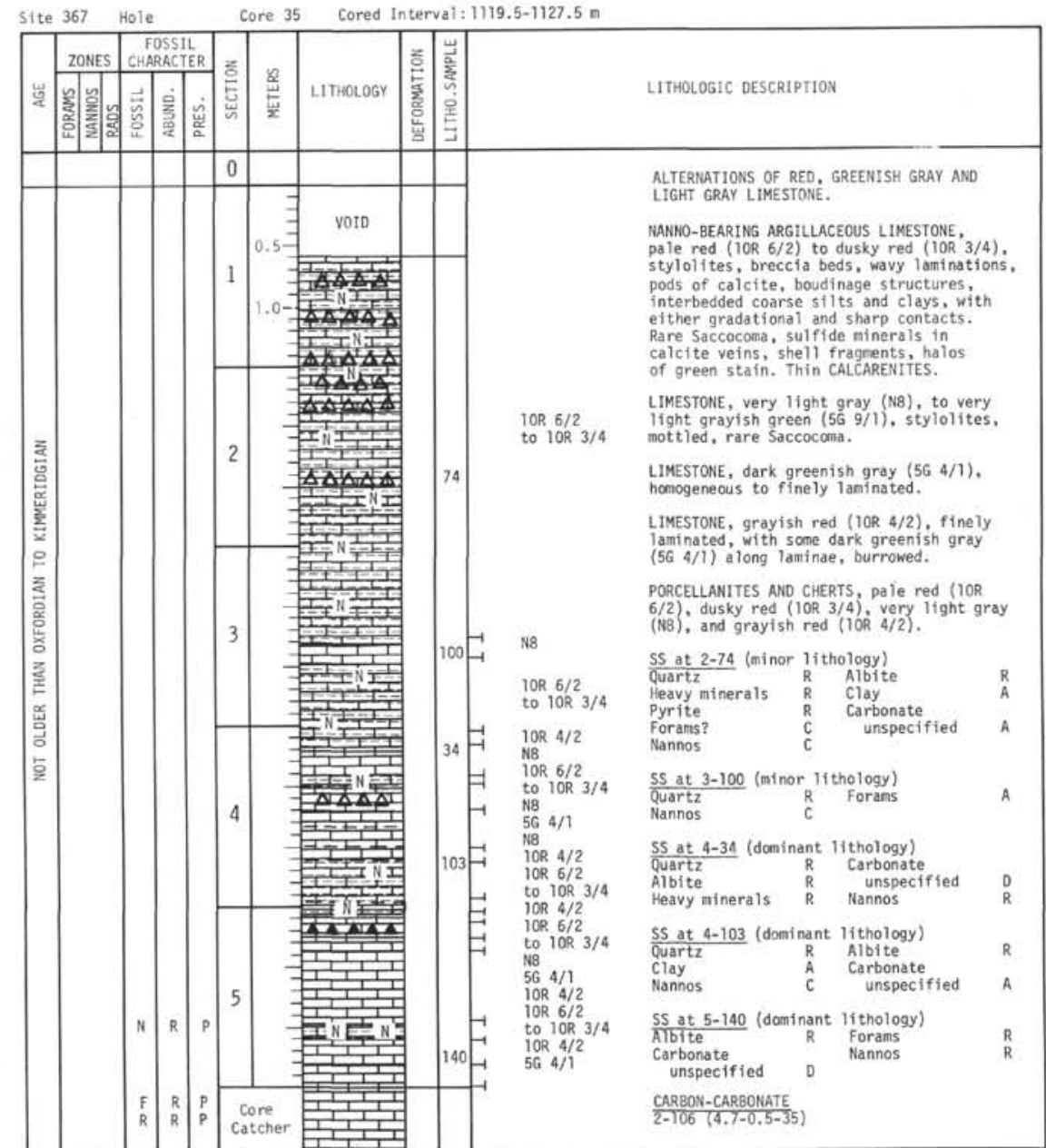
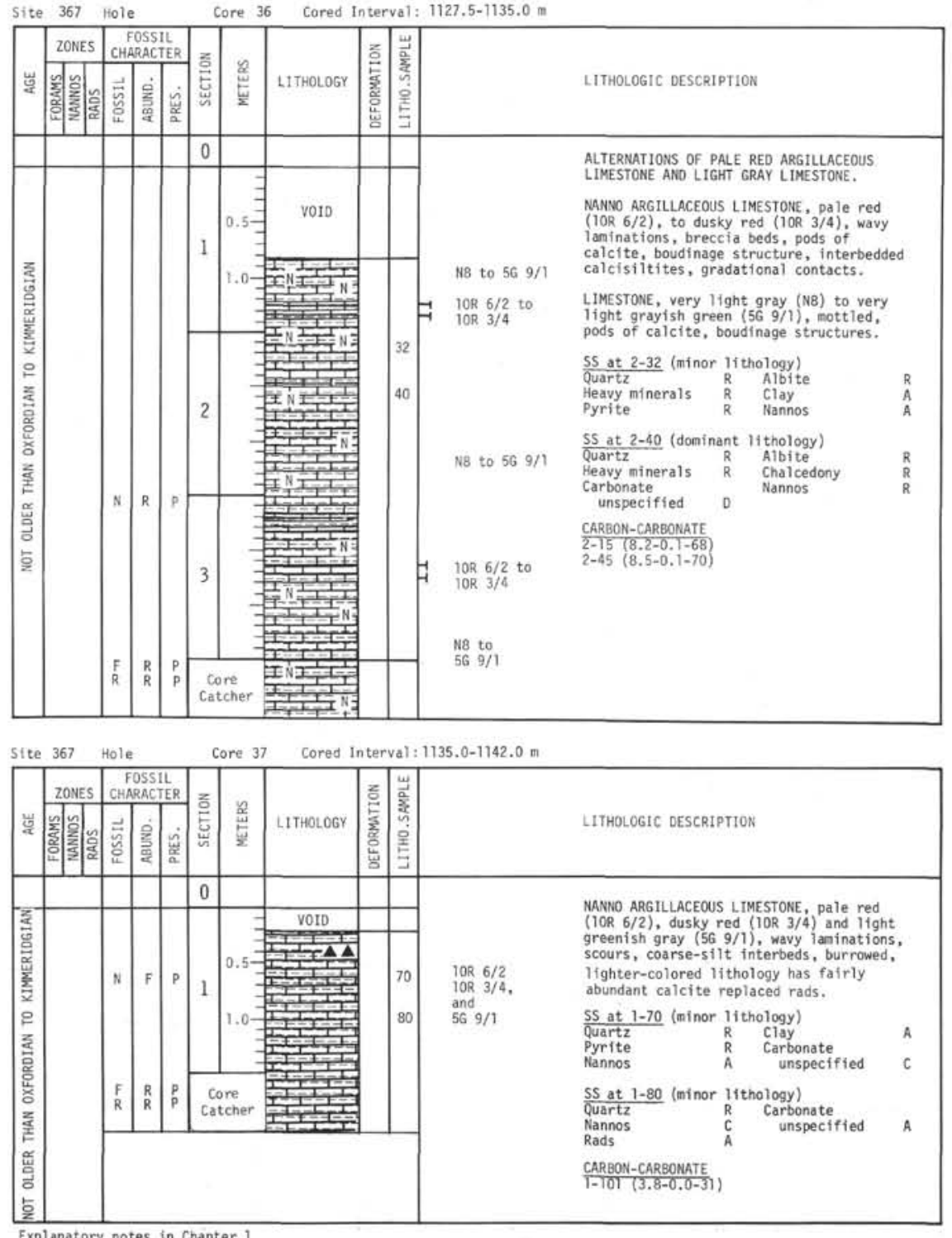


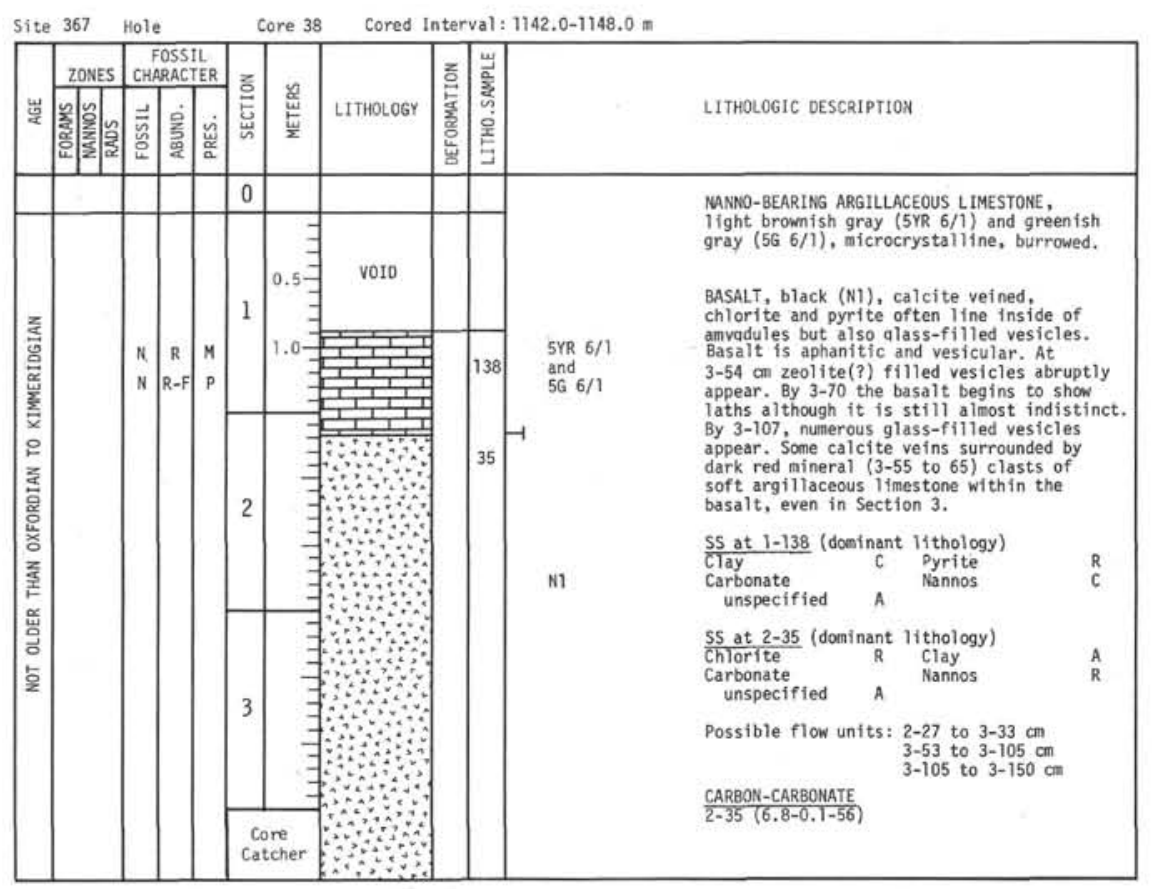

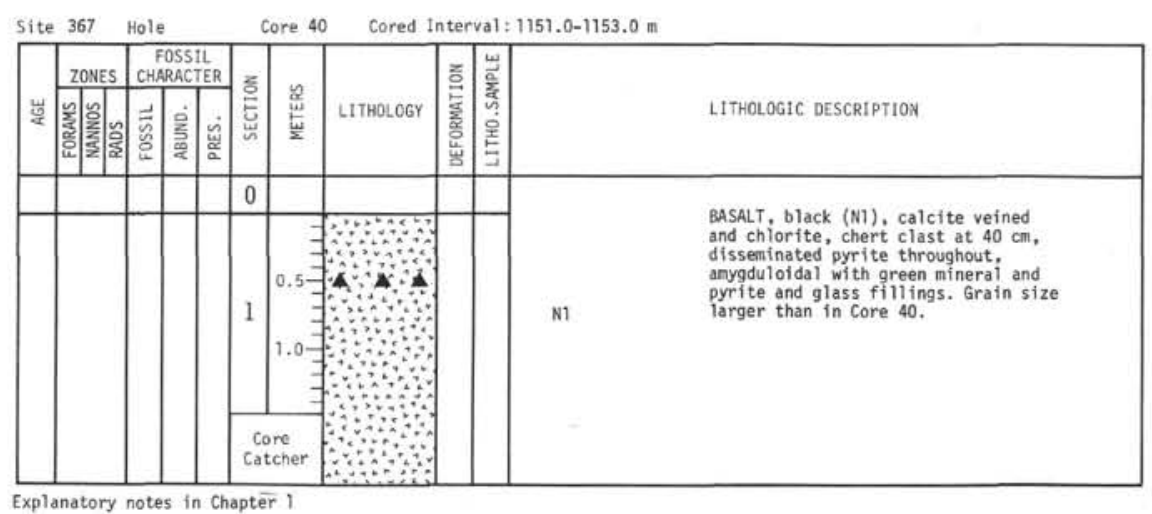

\begin{tabular}{|l|l|l|l|l|l|l|}
\hline Site 367 & Bole \\
\hline
\end{tabular}




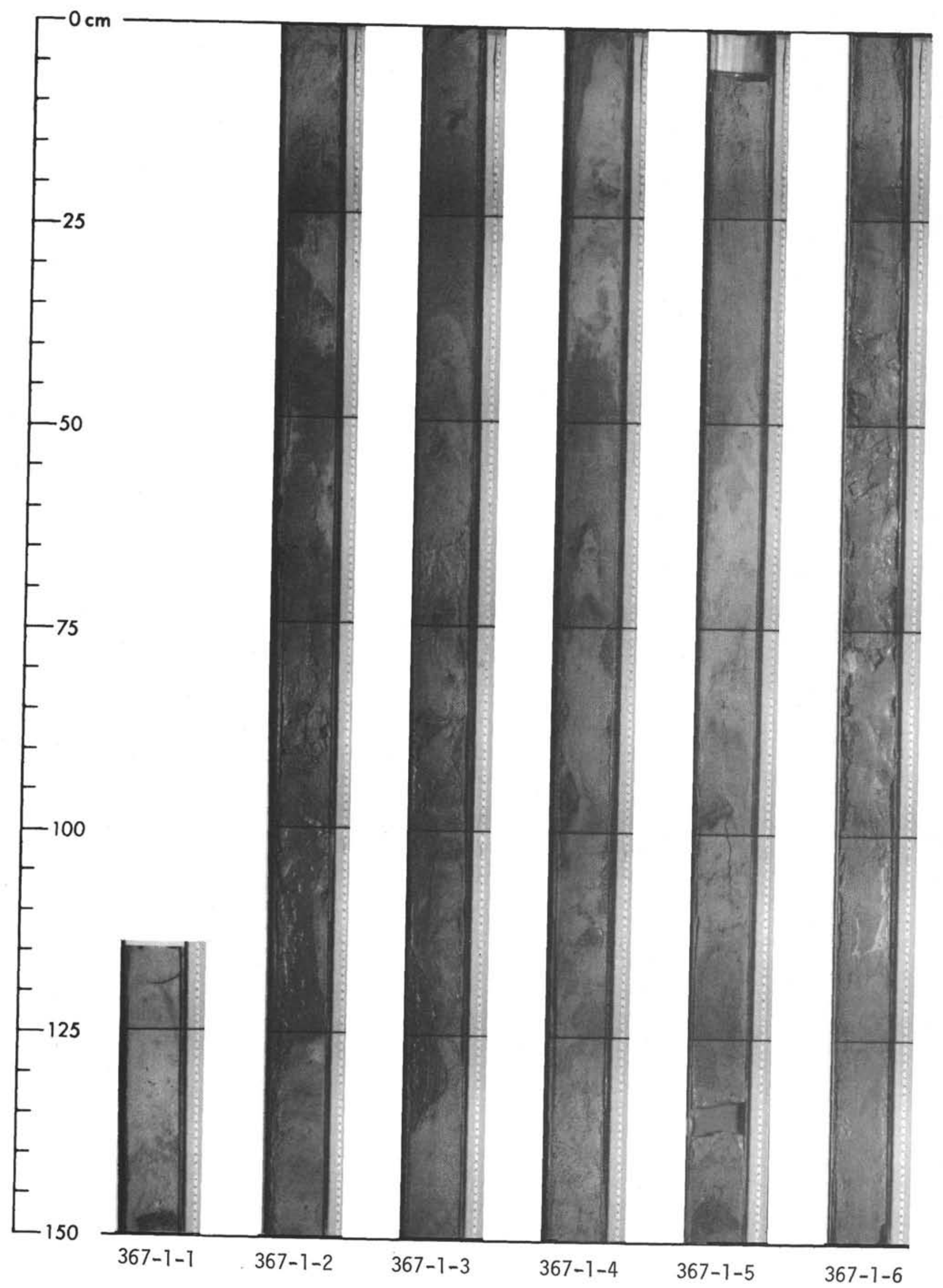




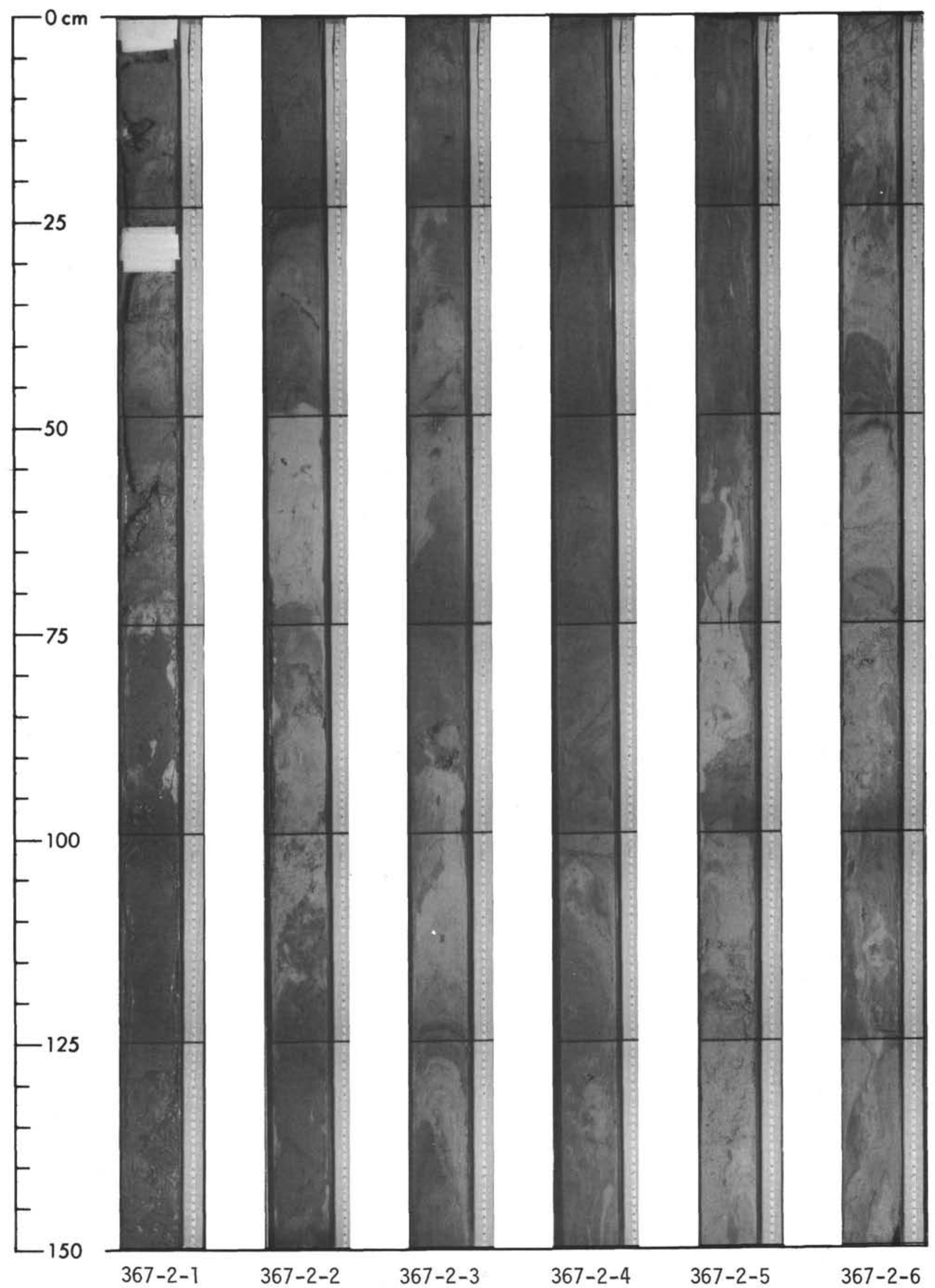




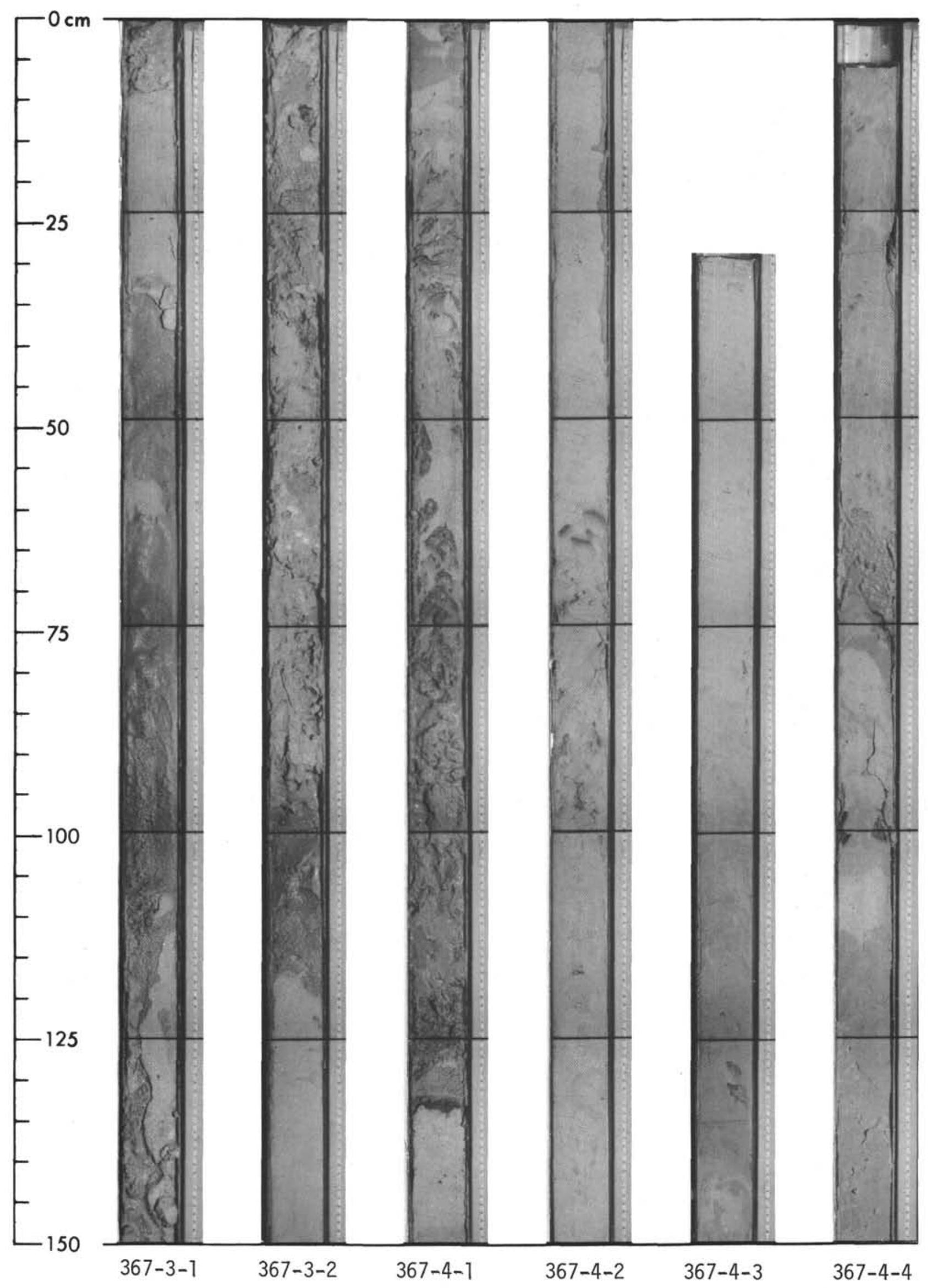




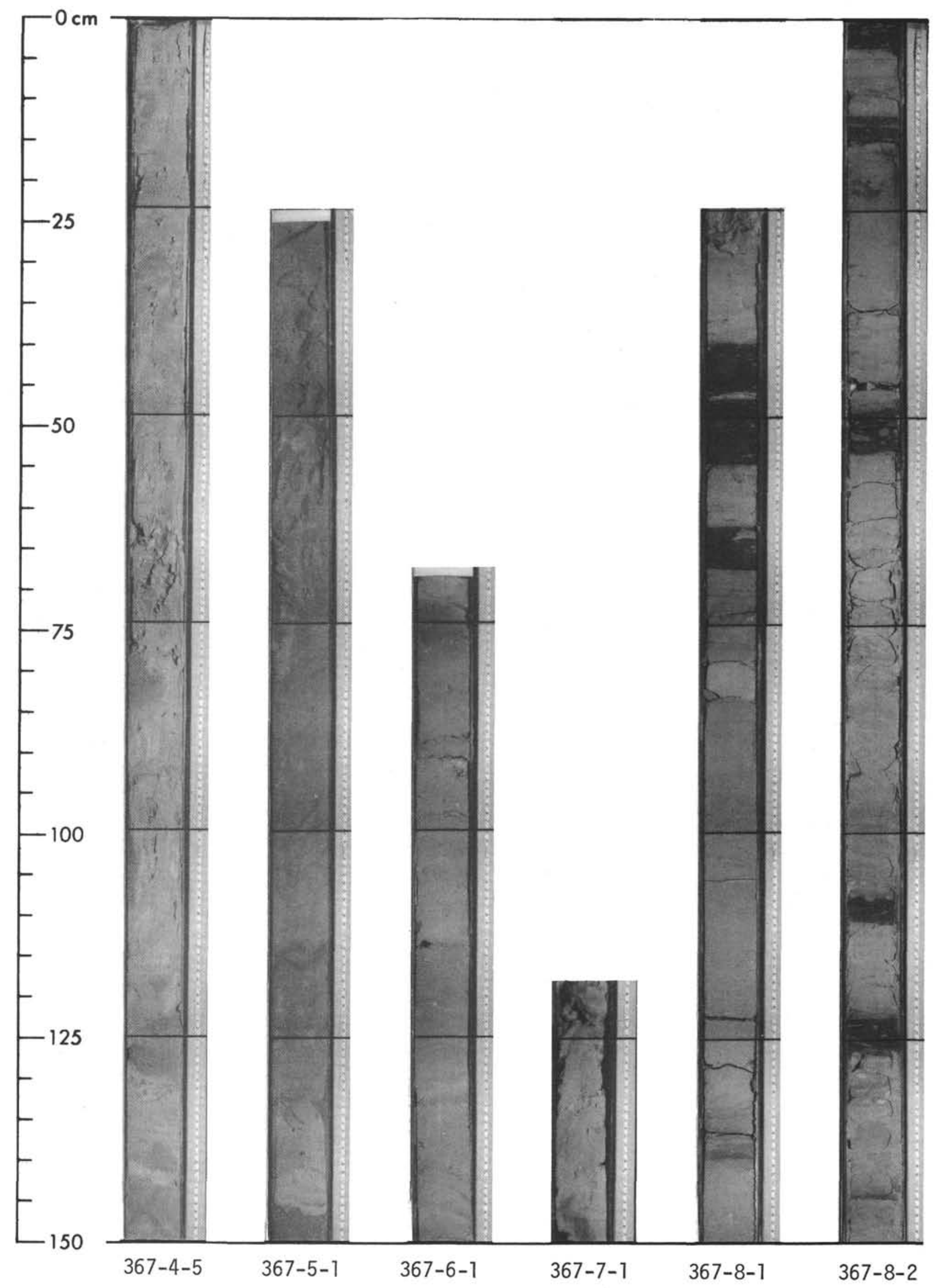




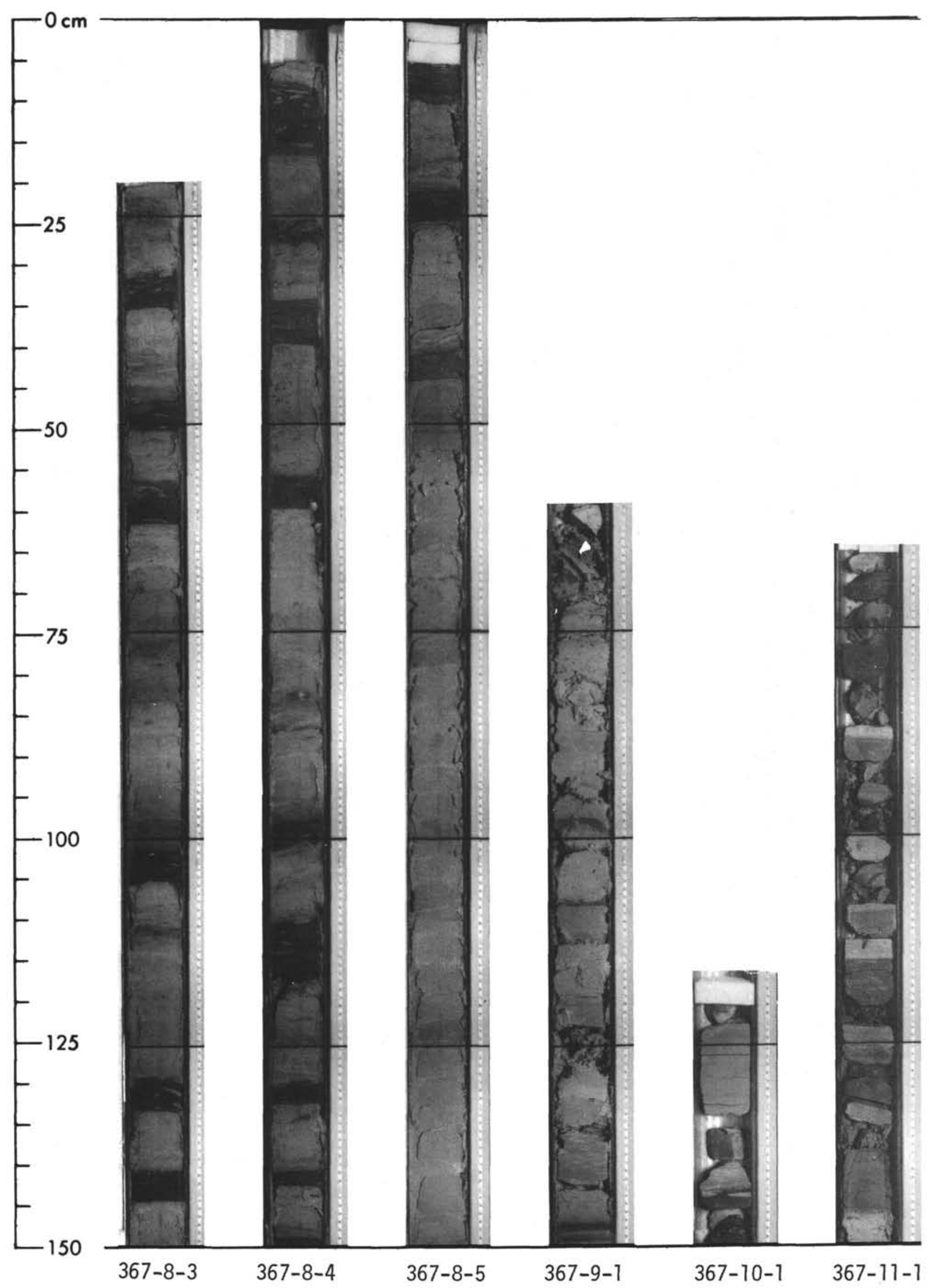




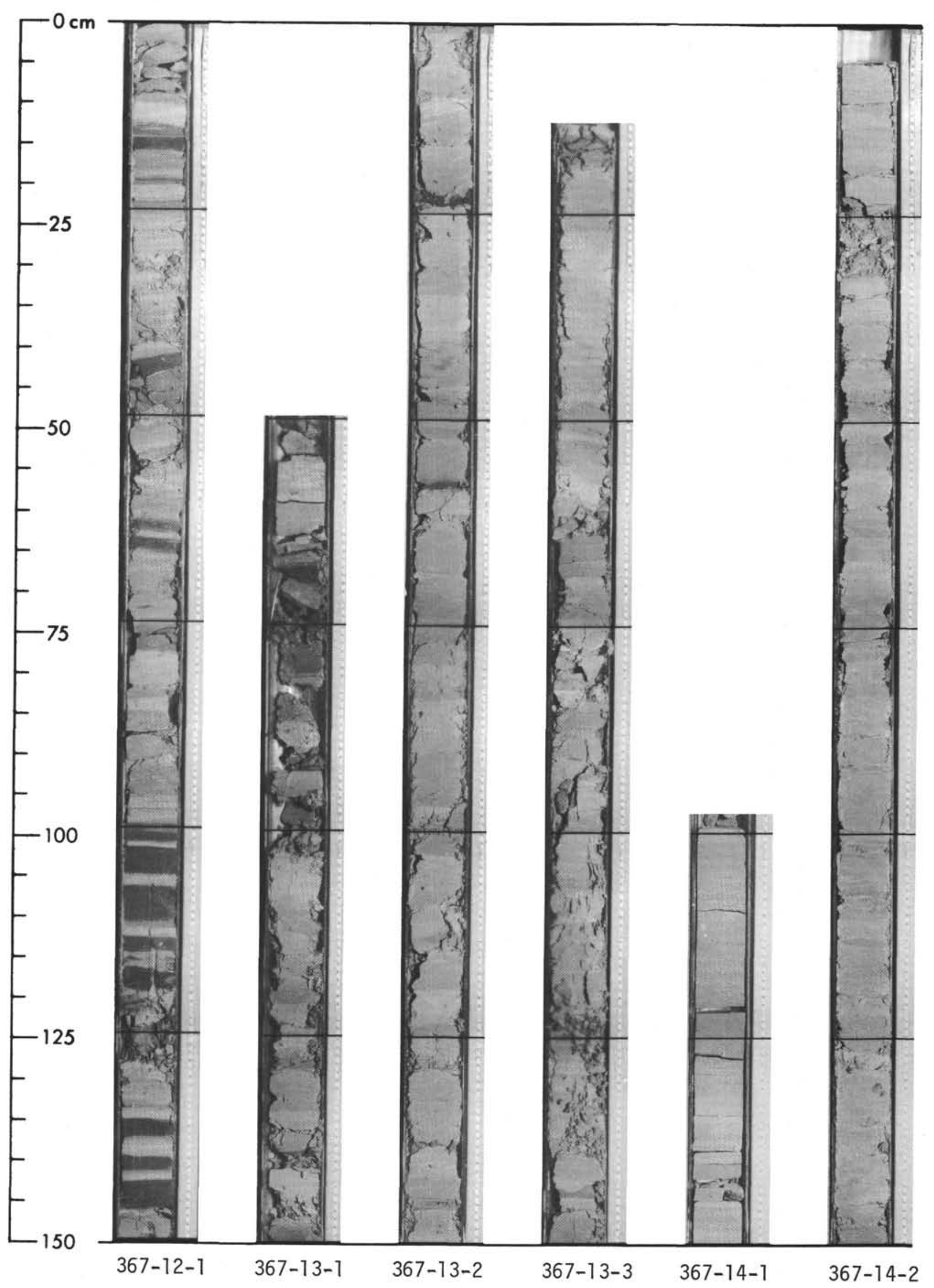




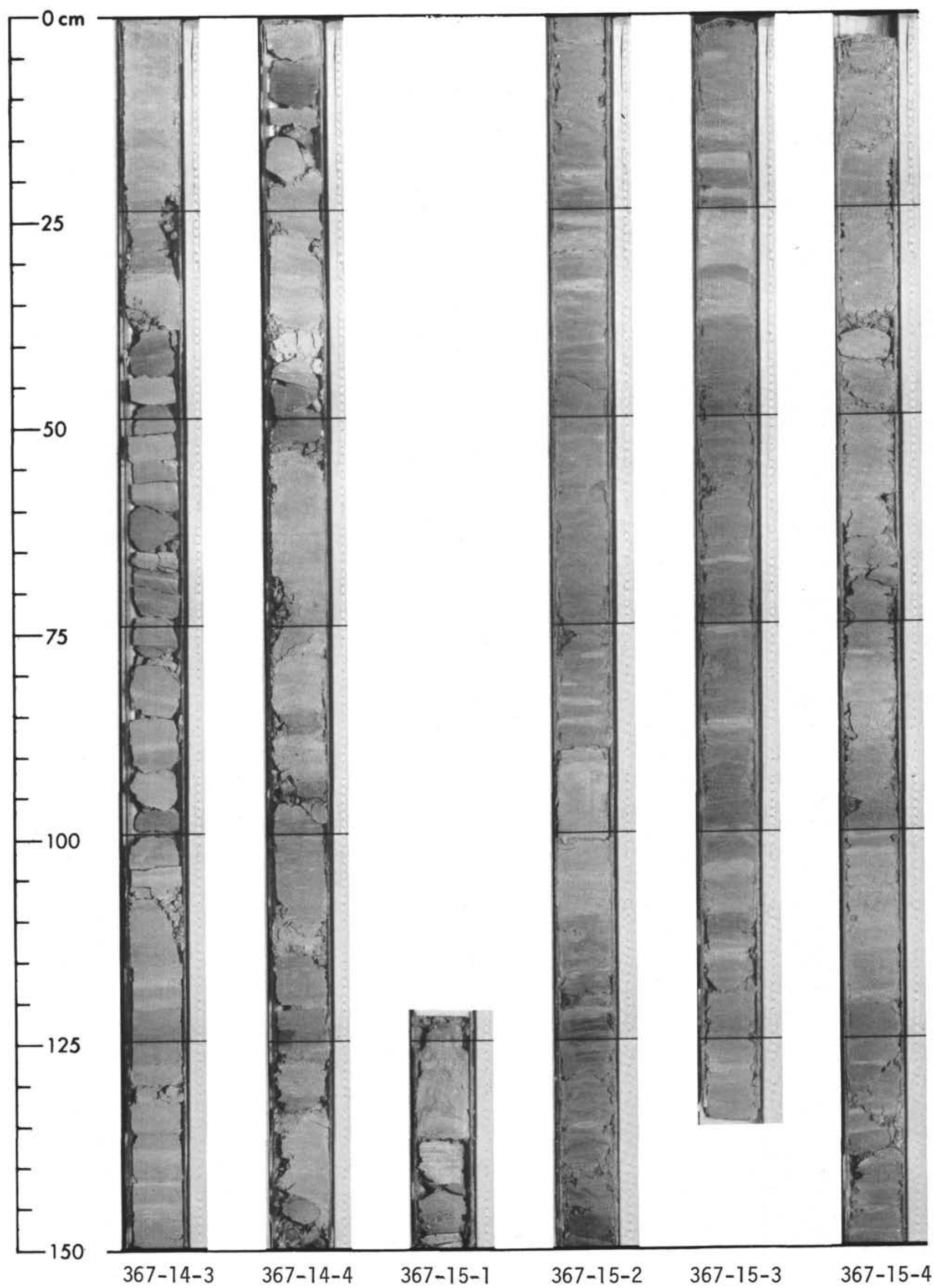




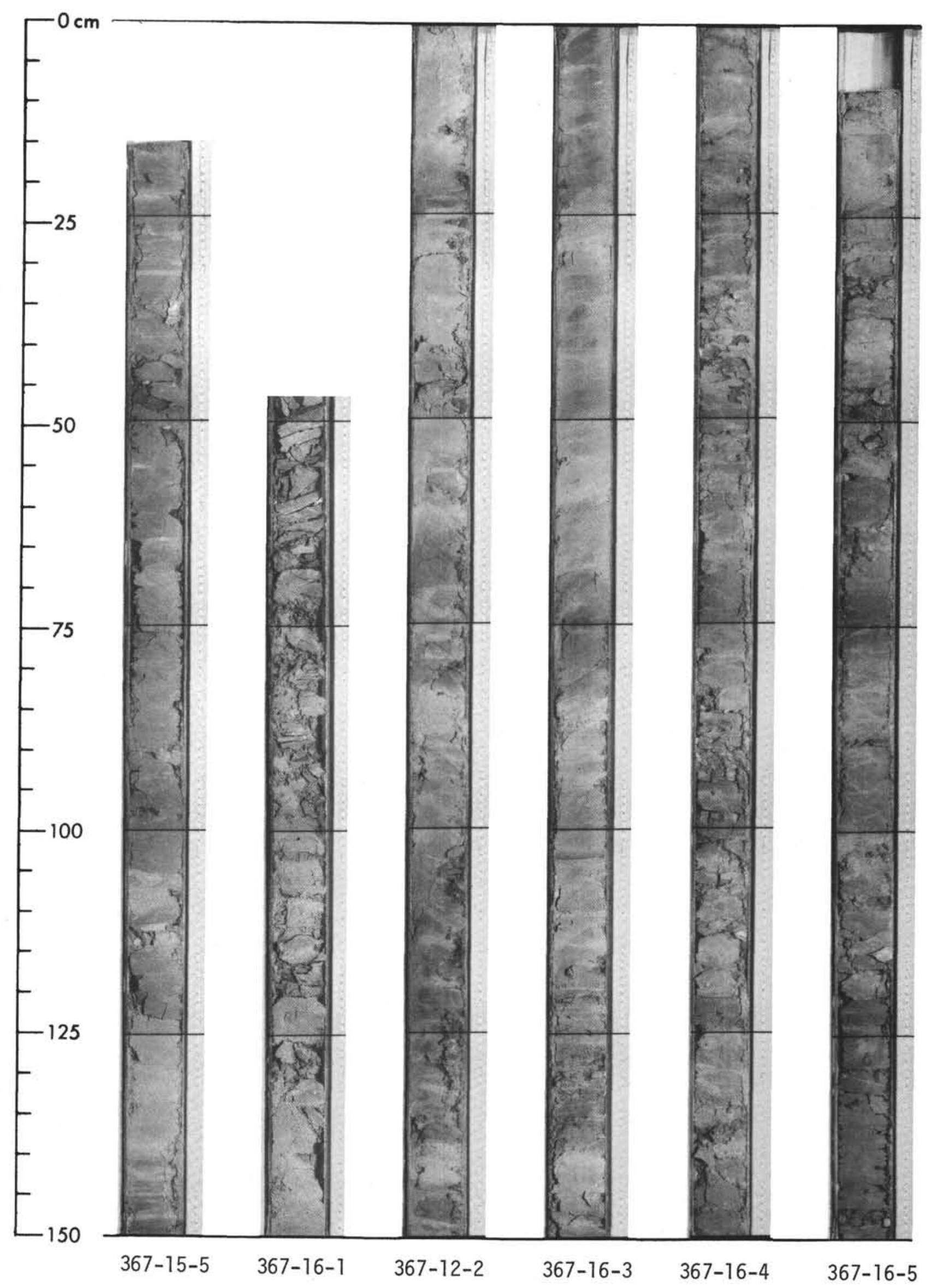




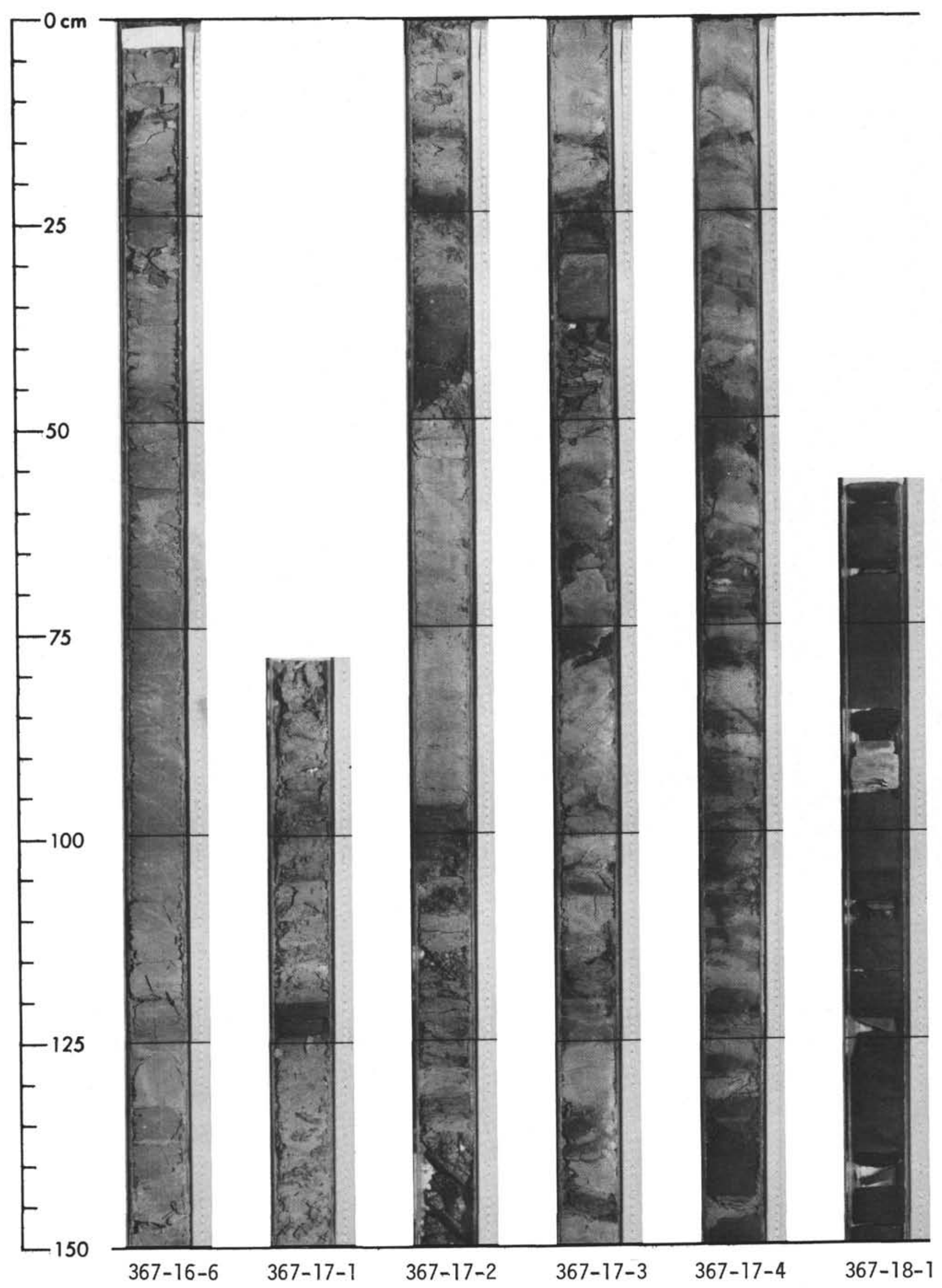




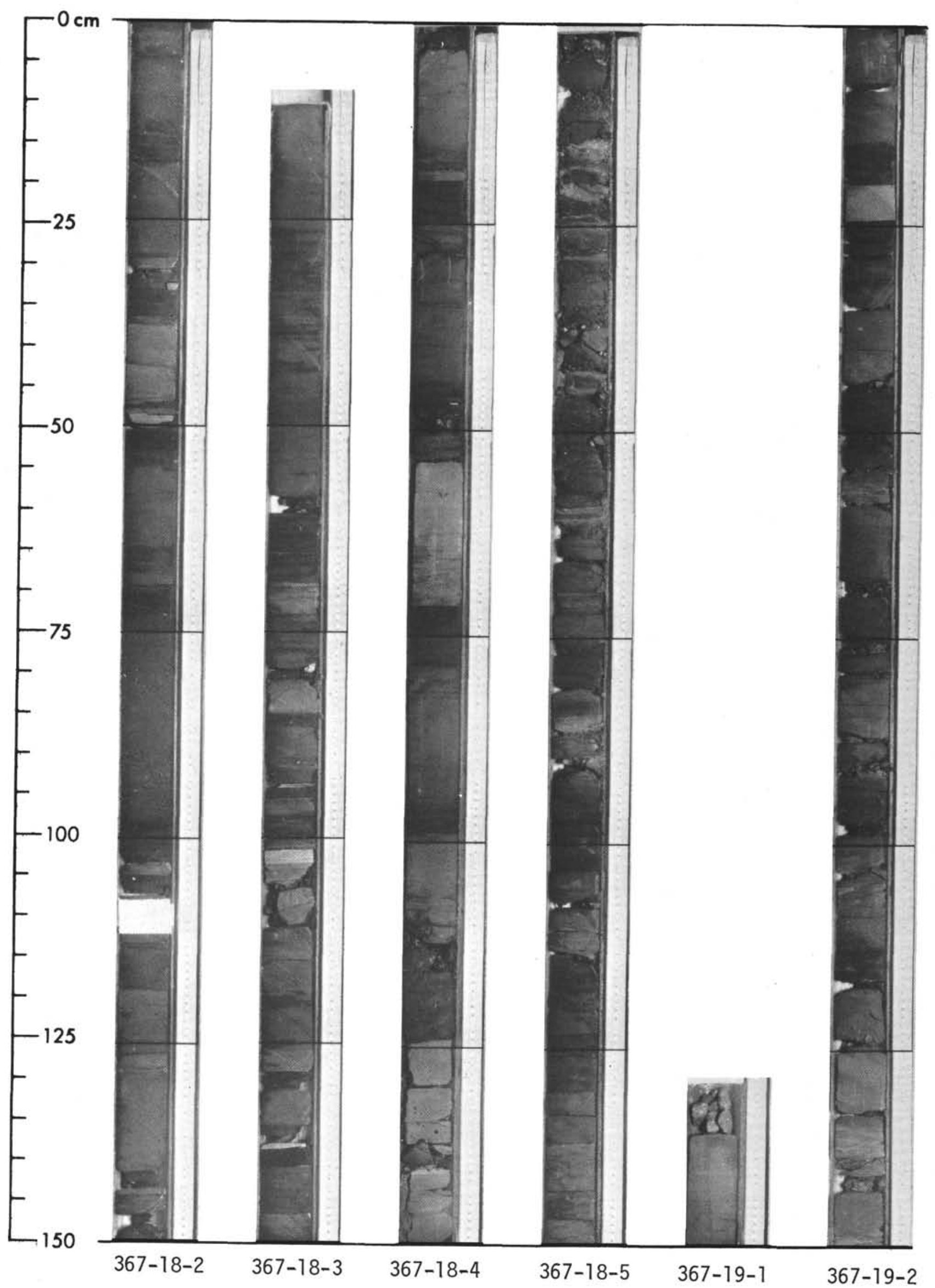




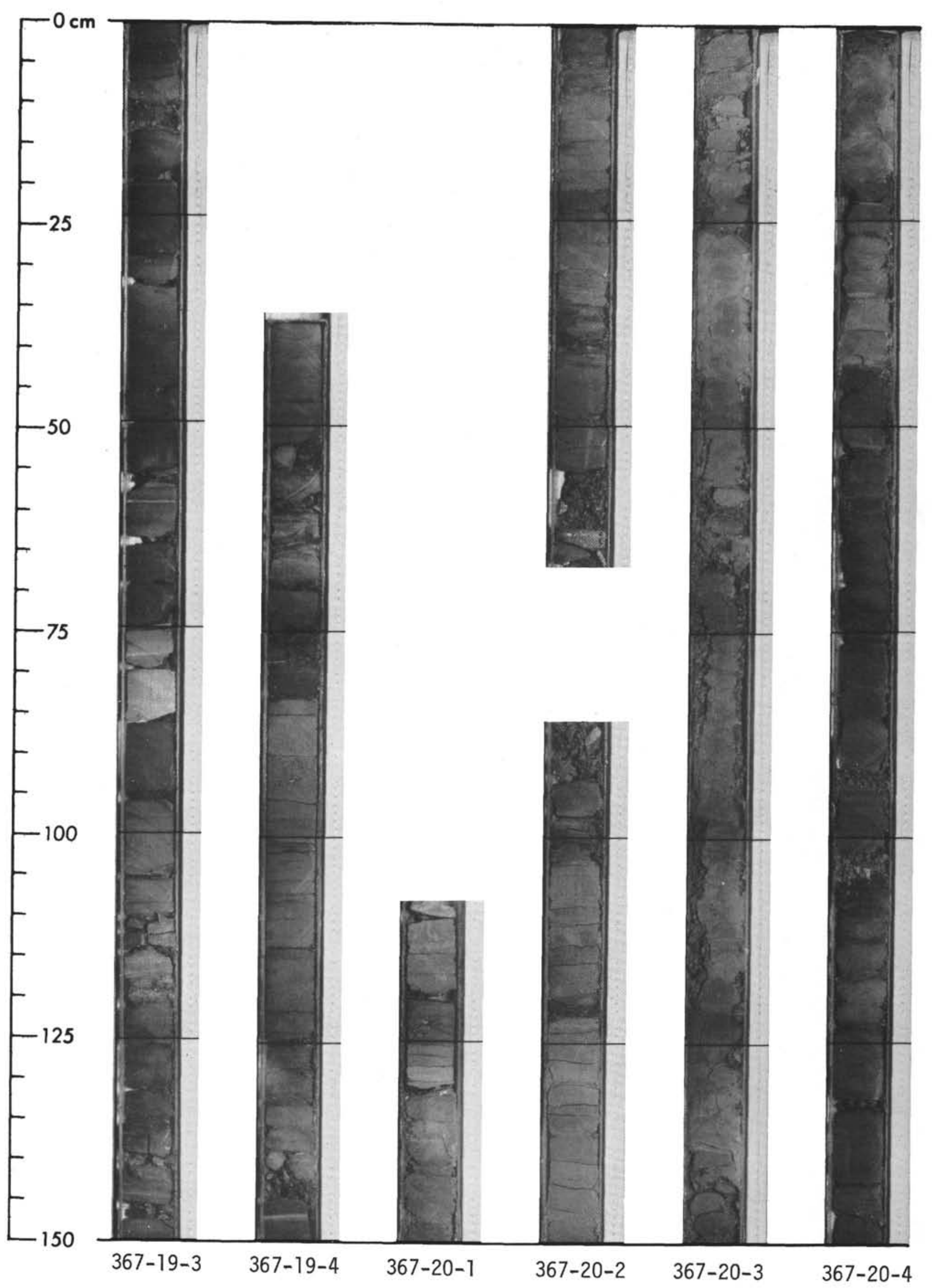




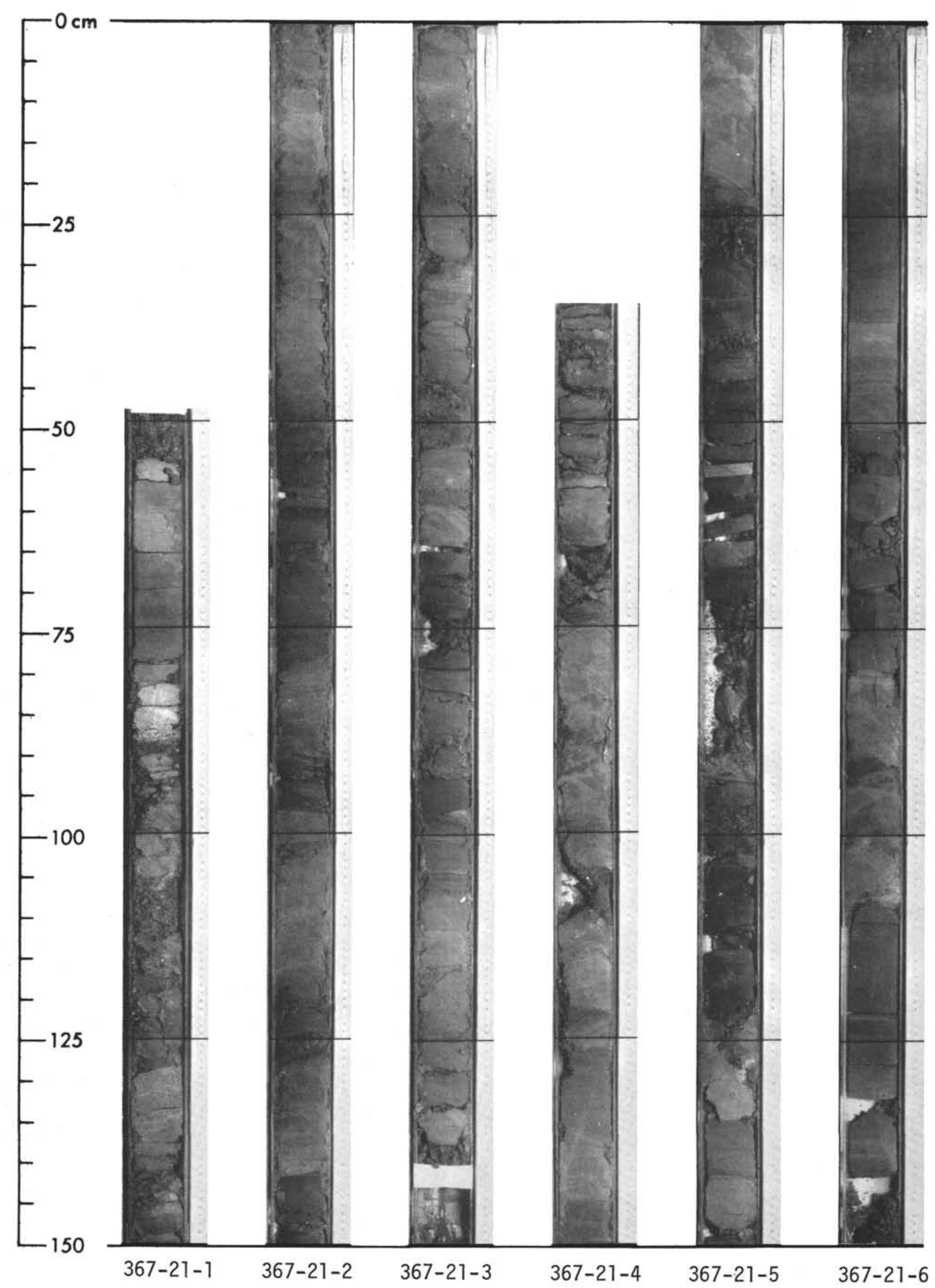




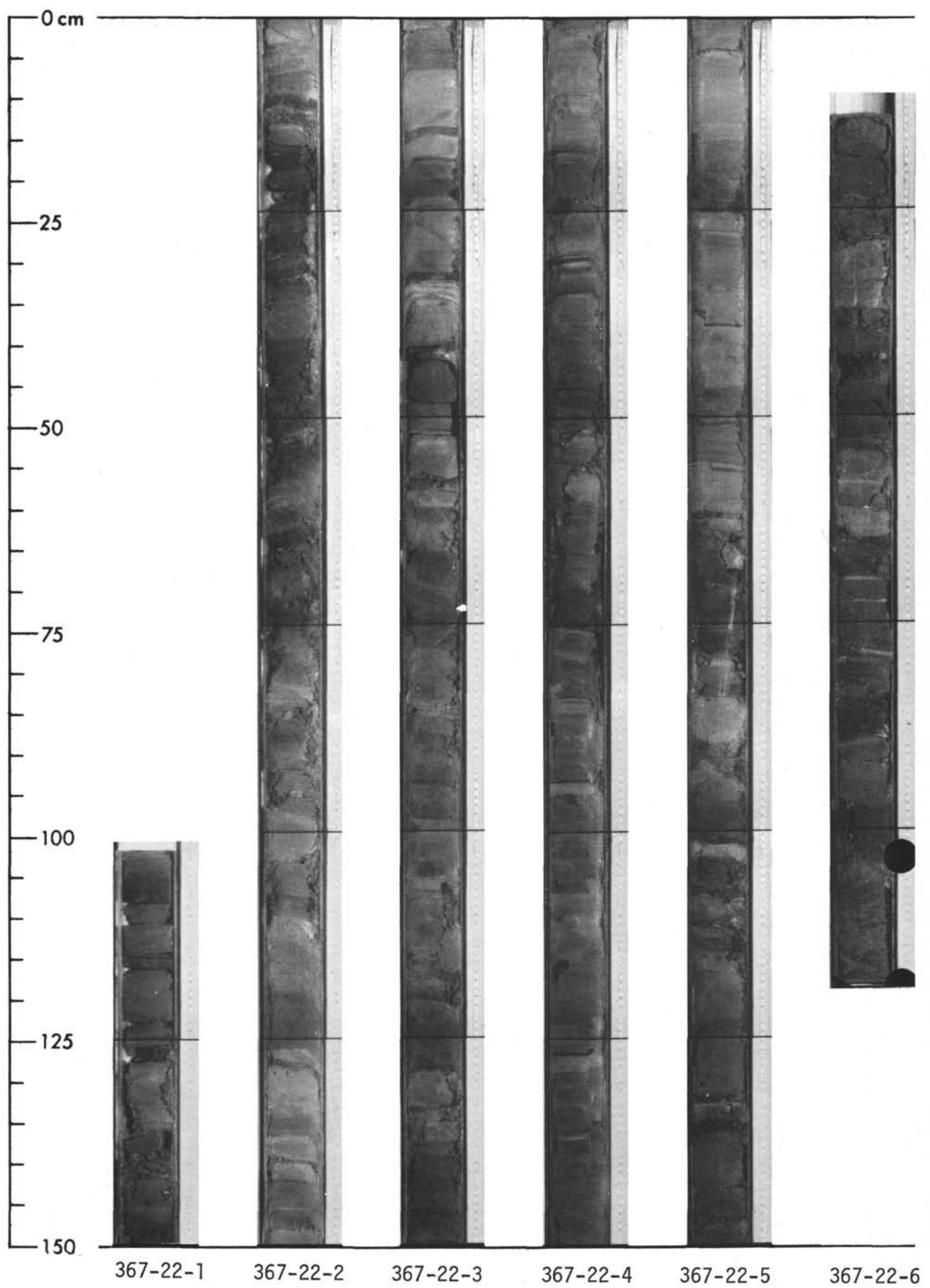




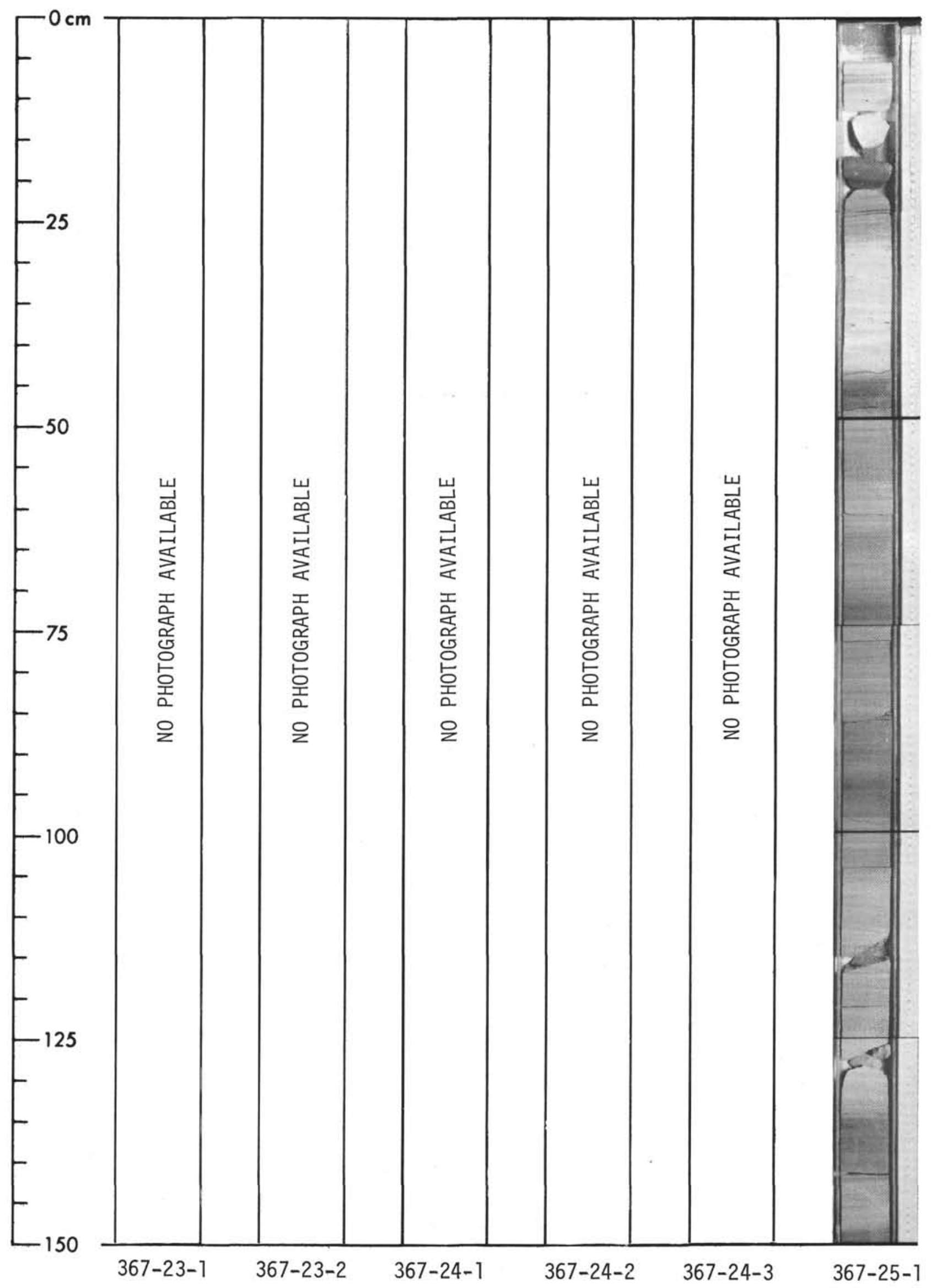


SITE 367: CAPE VERDE BASIN

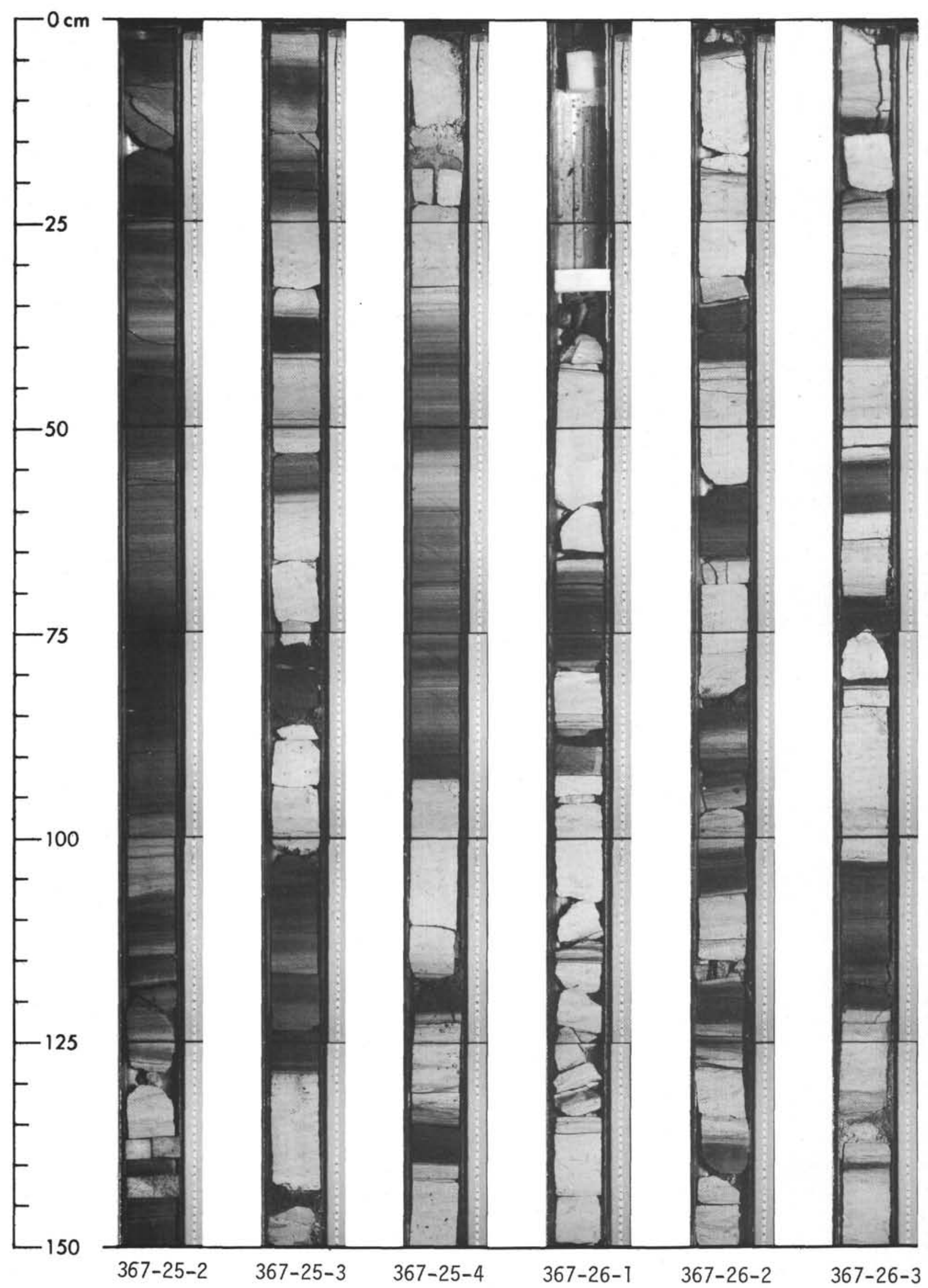


SITE 367: CAPE VERDE BASIN

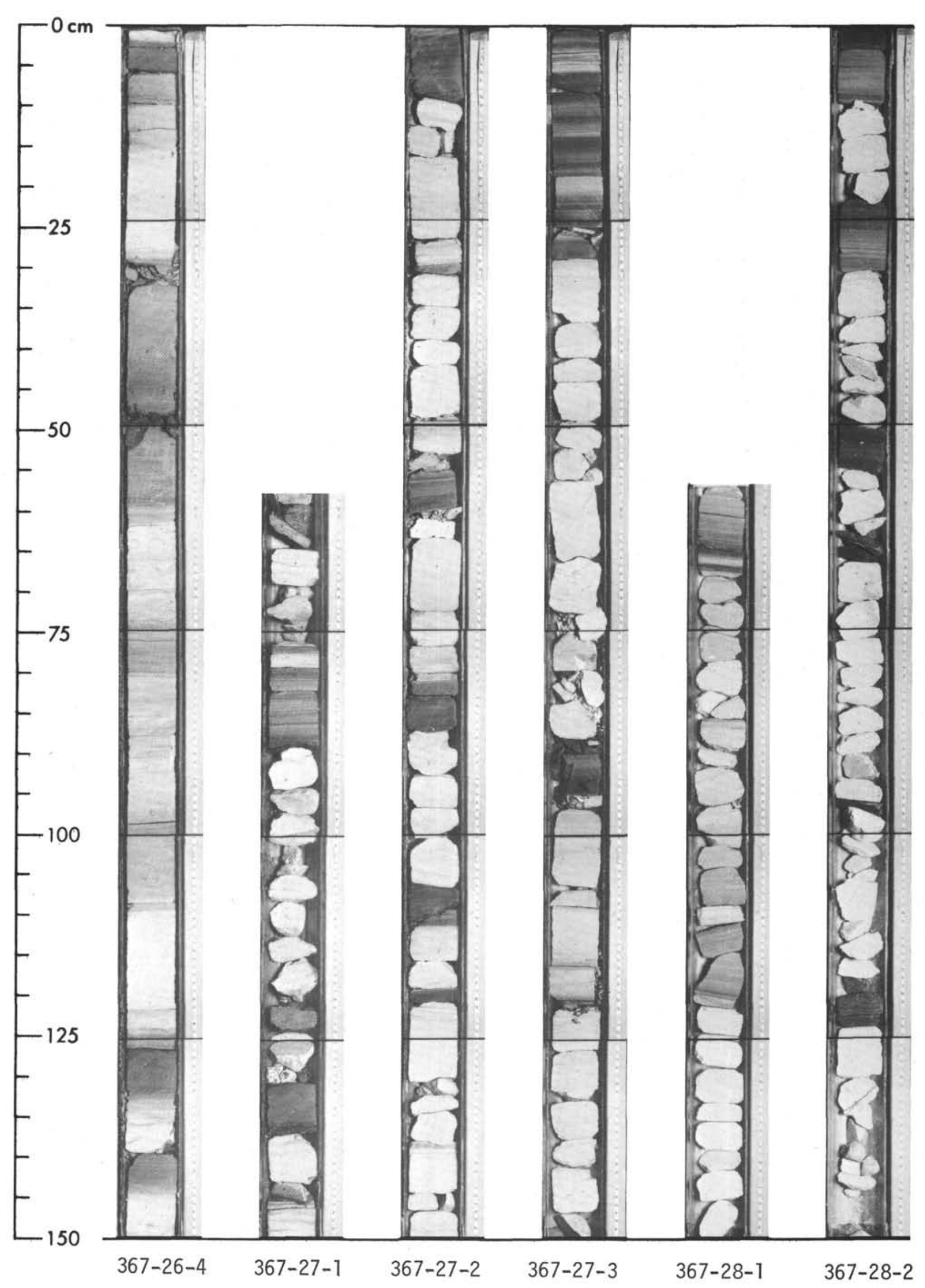




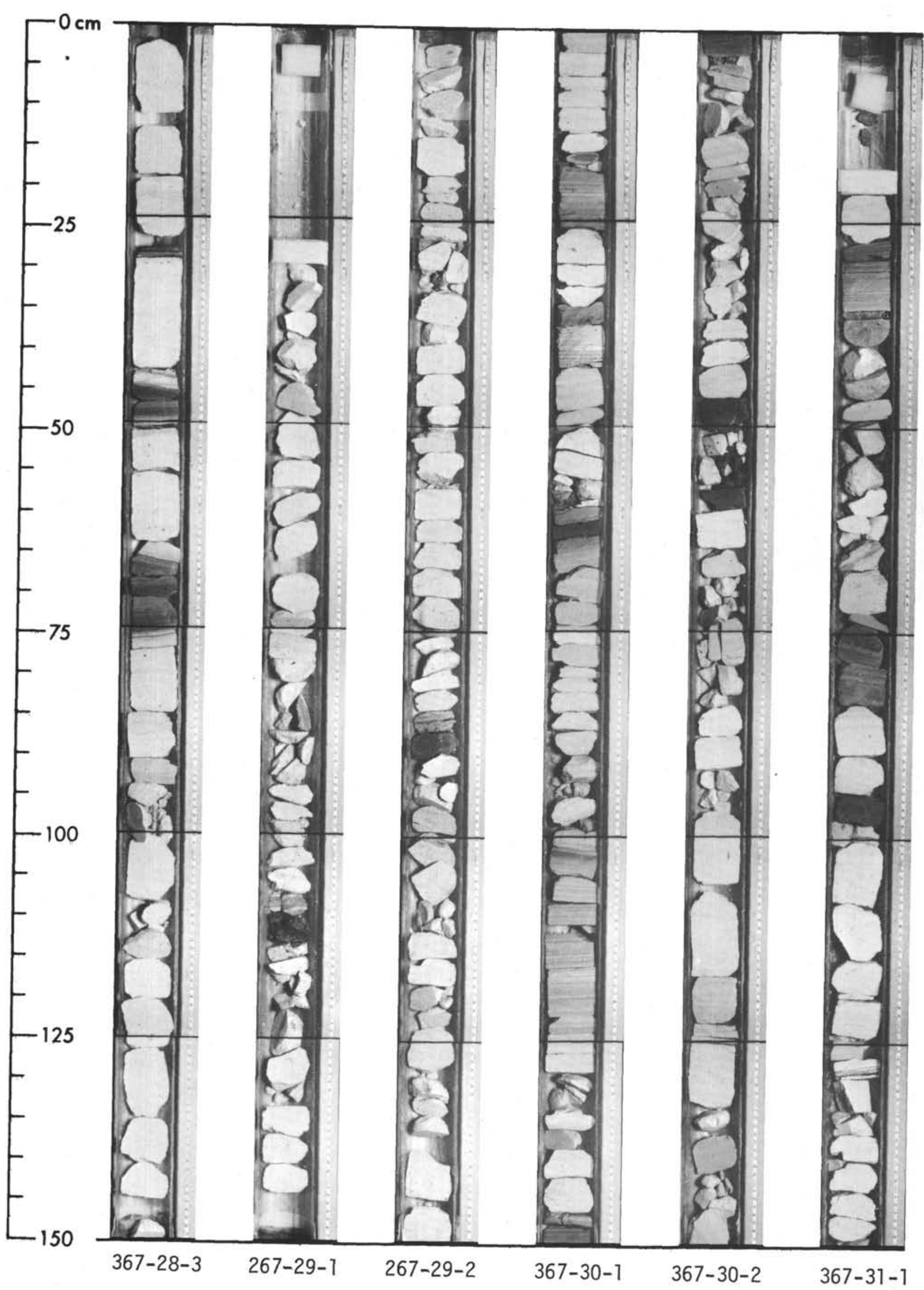


SITE 367: CAPE VERDE BASIN

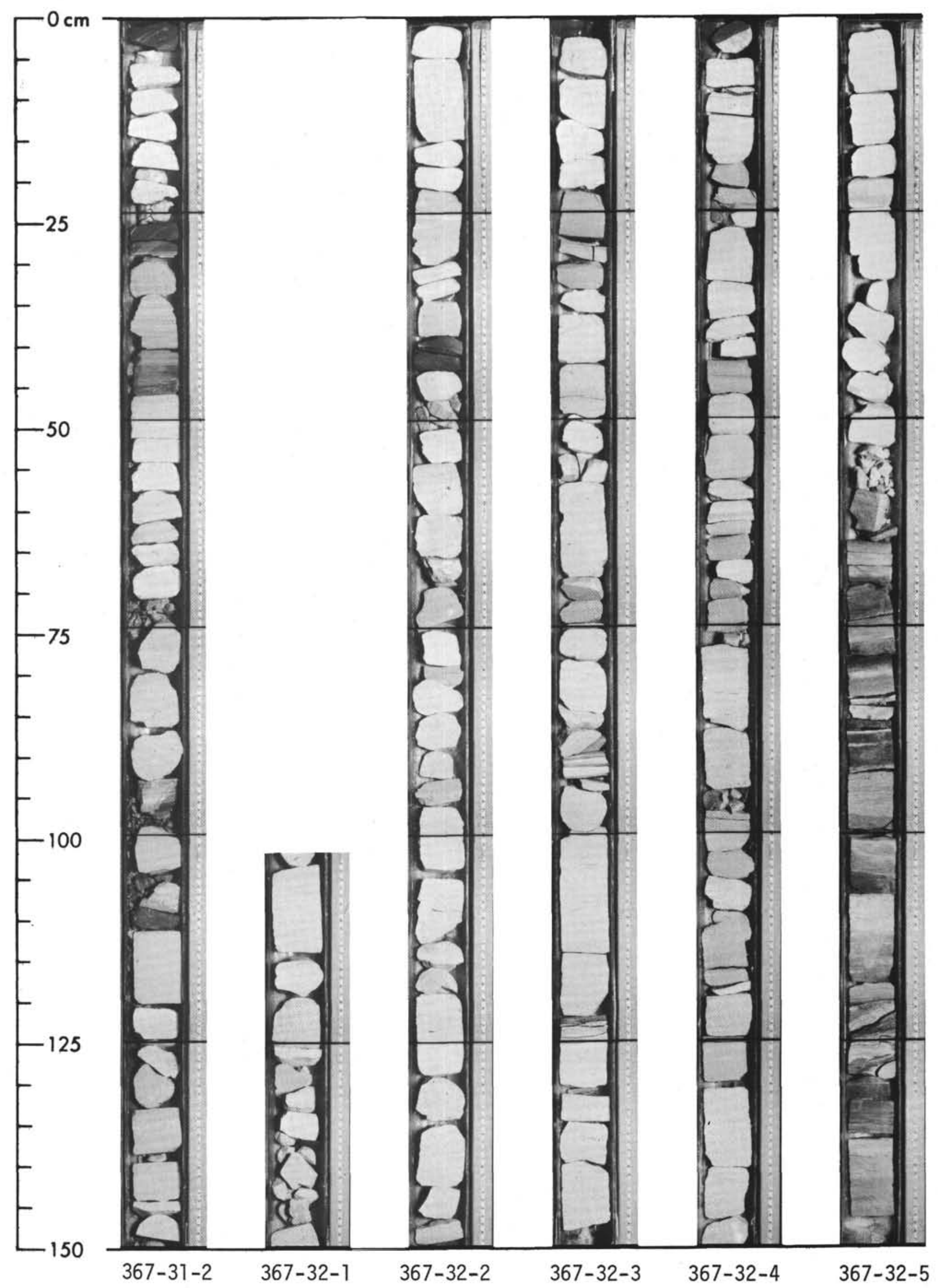




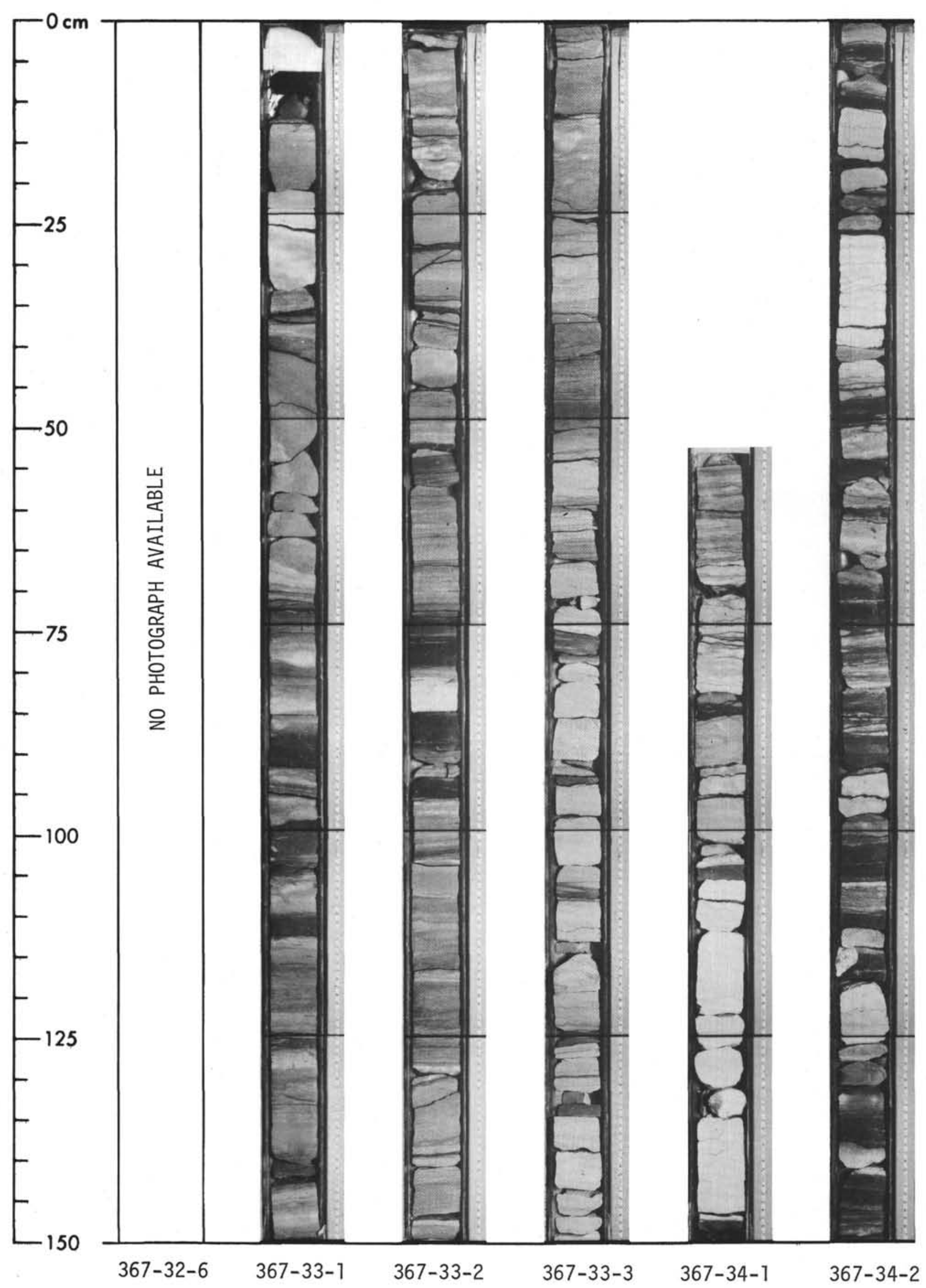




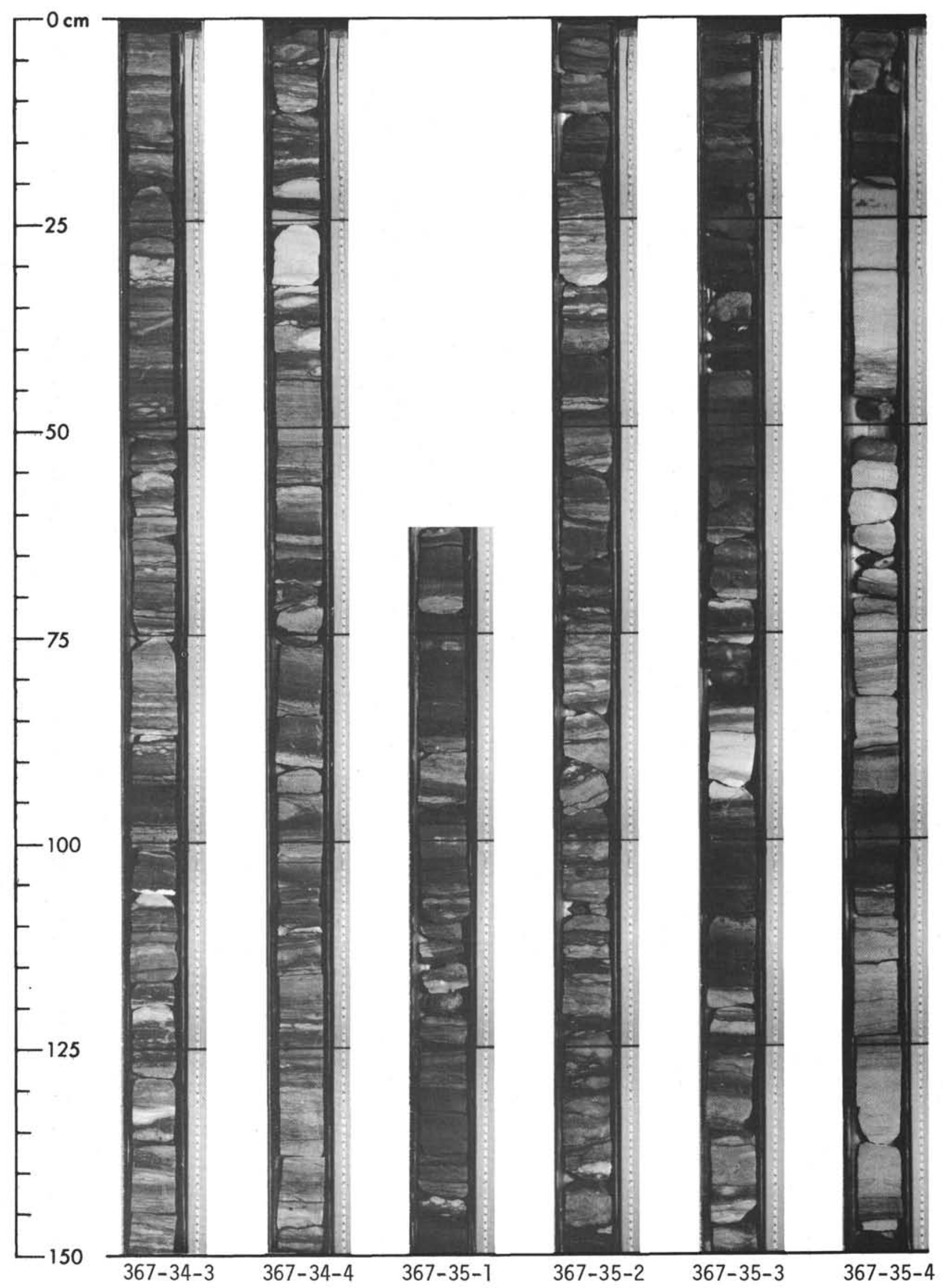




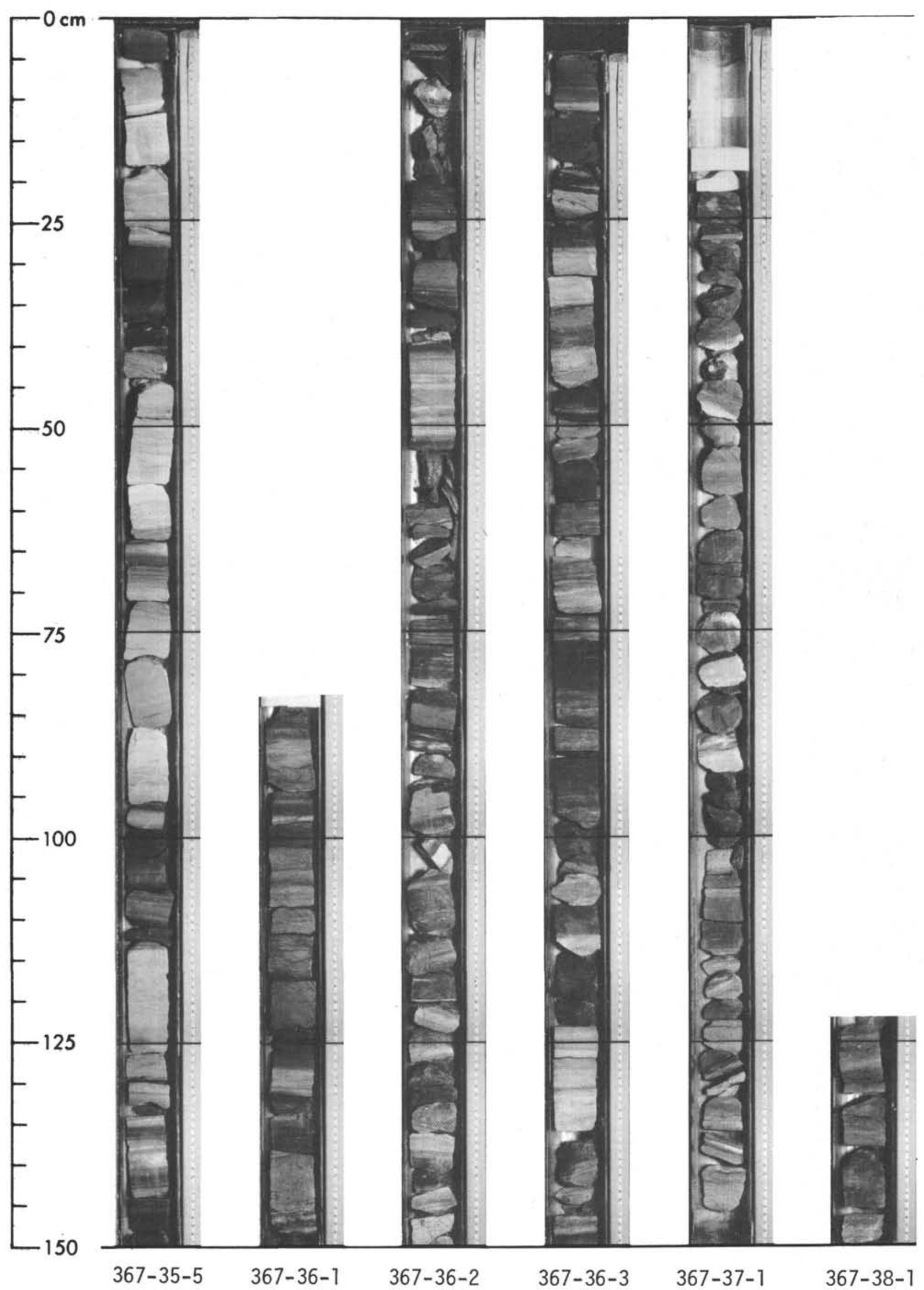




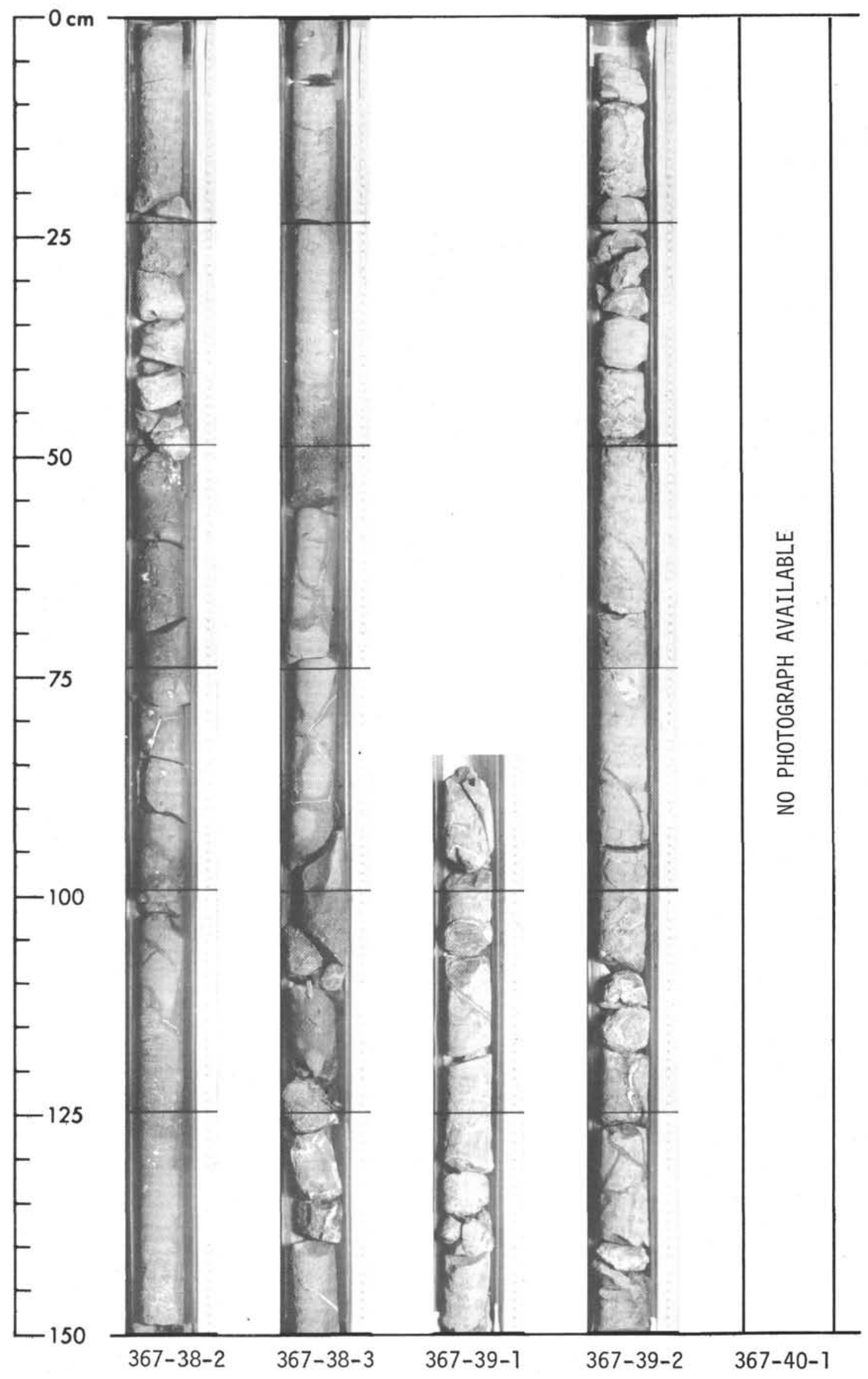

